INSTITUTO DE PESQUISAS ENERGÉTICAS E NUCLEARES Autarquia Associada à Universidade de São Paulo

\title{
INVESTIGAÇÃO DA RESISTÊNCIA À CORROSÃO DE FERROS FUNDIDOS COM MICROESTRUTURA BAINÍTICA E PERLÍTICA EM MEIO DE CONDENSADO SINTÉTICO.
}

Sandra Matos Cordeiro Costa

Dissertação apresentada como parte dos requisitos para obtenção do Grau de Mestre em Ciências na Área de Tecnologia Nuclear Materiais

Orientadora:

Profa. Dra. Isolda Costa

São Paulo

2014 


\section{AGRADECIMENTOS}

Como autora desta dissertação, gostaria de expressar meus agradecimentos às seguintes pessoas e instituições que, direta ou indiretamente, contribuíram para seu desenvolvimento.

Primeiramente, à Dra. Isolda Costa, por toda a sua confiança, paciência, dedicação, amizade, competência e orientação que viabilizaram este trabalho. E principalmente por acreditar em mim e na proposta deste trabalho, jamais poupando esforços no sentido de me ajudar a realizá-lo.

Ao meu marido André por sua paciência, apoio e amor demonstrados ao longo da duração deste mestrado. Por sempre acreditar e continuar acreditando, nos meus sonhos, se desdobrando por várias vezes para me auxiliar nessa caminhada.

Aos meus pais, irmãos, sobrinhos, cunhados, cunhadas e sogra, pelo total apoio recebido e pelas horas de prazer que os privei durante a confecção deste trabalho.

Aos amigos Viviane e Edmo, pelo apoio e incentivo para iniciar o mestrado, sem eles não teria conhecido a Dra. Isolda. Sem este incentivo eu jamais saltaria rumo ao desconhecido.

Aos meus colegas Paulo Morais e Edney que me auxiliaram durante a evolução deste trabalho, sempre buscaram me dar apoio para não desistir. Bem como auxílio para interpretar os resultados.

Ao IPEN e a USP, pelos conhecimentos transmitidos durante as aulas e a possibilidade de realizar este trabalho.

A empresa MAHLE Metal Leve S.A. pelo apoio profissional, permitindo assim a minha dedicação para concluir este trabalho.

Aos amigos do laboratório Metalúrgico da Mahle Metal Leve, Emerson, Washington, Nilson, Rodrigo, Luciano e Maurilio, por toda a ajuda na realização das análises, pela dedicação, precisão e qualidade em tudo que realizam. 
"Talvez meio caminho andado seja a gente acreditar no que faz. Mas acima de tudo, o que mais nos incentiva, o que mais nos valoriza $\mathrm{e}$ também mais nos torna conscientes de nossa responsabilidade é saber que os outros creem em nós. $E$ não há palavras que descrevam o que sentimos ao saber dos sacrifícios a que eles se impõem por crerem não apenas em nós, mas também no que cremos".

Albert Einstein. 


\section{RESUMO}

As indústrias que desenvolvem motores de combustão interna têm como preocupação atual prover motores que sejam cada vez menos poluentes, uma vez que a preocupação com a preservação do meio ambiente é intensa em todo o mundo. No entanto, com o desenvolvimento de novas tecnologias destinadas à redução das emissões, a condensação dos gases, provenientes da combustão, está sendo promovida dentro das câmaras de combustão dos veículos. Ácidos, como sulfúrico e nítrico, são gerados pela condensação destes gases. Esta condensação está associada às altas taxas de recirculação de gases de escape, conhecido como EGR, (termo em inglês para "Exhaust Gas Recirculation"). Consequentemente, problemas de corrosão nos componentes do motor estão aumentando, especialmente em camisas de cilindro em ferro fundido. Neste estudo, foi investigada a resistência à corrosão de dois ferros fundidos, um de microestrutura perlítica e o outro com microestrutura bainítica, em soluções de condensado natural e sintético de motores movidos a diesel. Os resultados foram associados às microestruturas e as composições químicas dos materiais estudados. Resultados de testes de imersão e ensaios de espectroscopia de impedância eletroquímica, bem como de curvas de polarização potenciodinâmicas, indicaram que os dois materiais não apresentam resistência à corrosão nos meios de ensaio adotados. $O$ ataque intenso da matriz observado em ambos os materiais observado pelos ensaios de imersão, mostraram a atuação do mecanismo eletroquímico de corrosão por grafitização. Este mecanismo causa o ataque localizado e destrutivo da matriz de ferrita $(\alpha-\mathrm{Fe})$, que funciona como anodo enquanto as grafitas atuam como áreas catódicas. Enquanto em meio ácido não foi possível observar uma diferenciação entre os dois tipos de ferros fundidos estudados, em meio neutro e aerado, o ferro fundido bainítico mostrou resistência à corrosão superior à do ferro fundido perlítico. 


\begin{abstract}
The industries that develop internal combustion engines have the current concern on providing less polluting engines, due to the worldwide apprehension on the environment preservation. However, with the development of new technologies to reduce emissions, condensation of gases from combustion is being promoted within the combustion chambers of vehicles. Acids, such as sulfuric and nitric, are generated by these gases condensation. This condensation is associated with high rates of exhaust gas recirculation, known as EGR, (the English term for Exhaust Gas Recirculation). Consequently, corrosion problems of engine components are increasing, especially in cylinder liners made with cast iron. In this study, the corrosion resistance of two cast irons, one with a pearlitic microstructure and the other with a bainitic one, has been investigated in the natural solution obtained by condensation of the gases from diesel engines combustion or in a synthetic solution that simulates the composition of the condensate gases. The results were associated with the chemical compositions and microstructures of the materials studied. The results of immersion tests and electrochemical impedance spectroscopy tests, as well as potentiodynamic polarization curves, indicated that both materials do not exhibit significant differences in their corrosion resistance in the solutions adopted for testing. The intense attack of the matrix observed during immersion tests showed the electrochemical corrosion mechanism of graphitization in both materials. This mechanism causes localized attack of the ferrite matrix $(\alpha-\mathrm{Fe})$, which acts as the anodic areas whereas the graphite act as the cathodic ones. Though in acid medium has not been possible to observe a distinction between the corrosion resistance of the two types of cast irons studied, in neutral and aerated environment, the bainitic cast iron showed higher corrosion resistance comparatively to the pearlitic cast iron .
\end{abstract}




\section{SUMÁRIO}

Página

RESUMO

ABSTRACT

1 INTRODUÇÃO

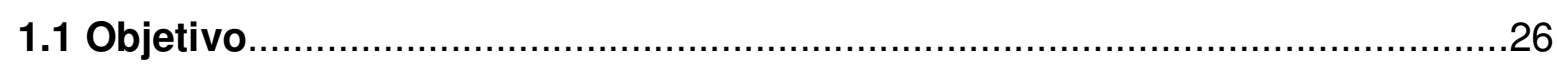

2 REVISÃO DA LITERATURA

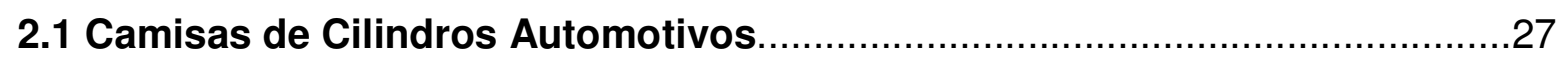

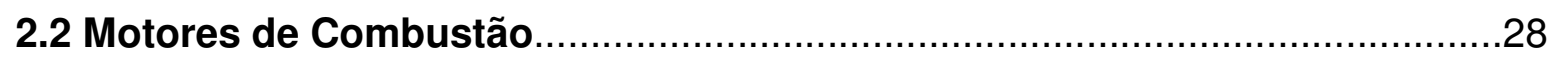

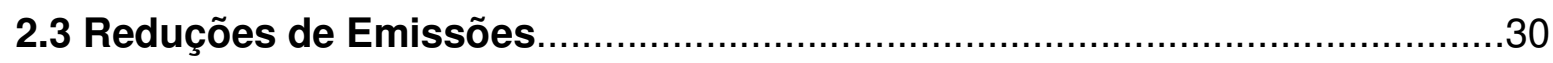

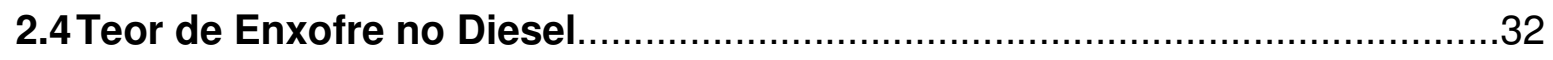

2.5 Ferro Fundido

2.5.1 Características de composição química, estrutura e resistência à corrosão dos

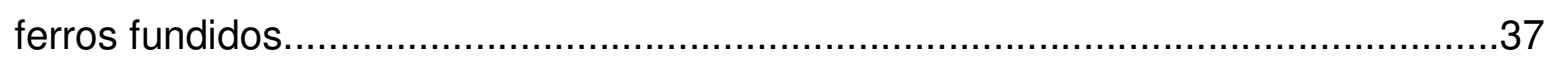

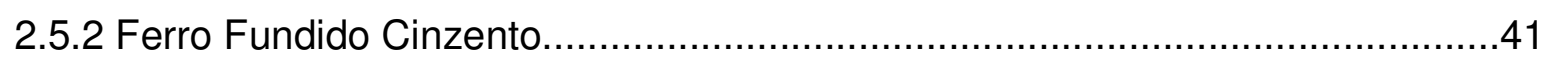

2.5.2.1 Ferro Fundido Cinzento Perlítico............................................................

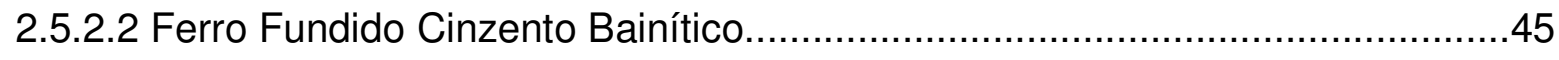

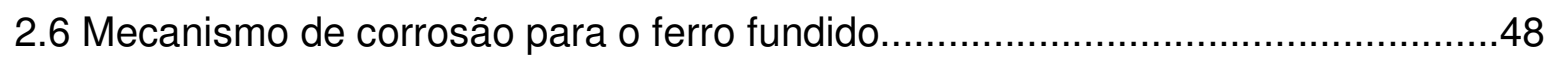

2.6.1 Corrosão do ferro fundido em diferentes meios...........................................50

2.6.2 Comportamento de corrosão do ferro do ferro fundido e características dos

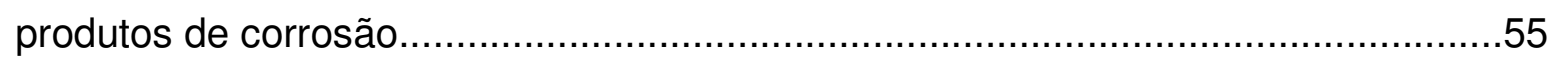

2.6.3 Efeito da microestrutura na corrosão do ferro fundido....................................58

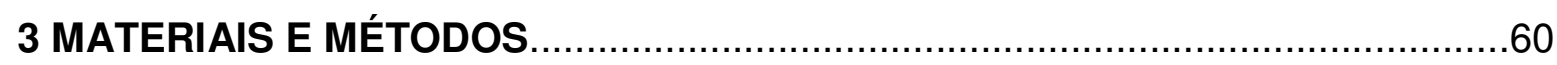

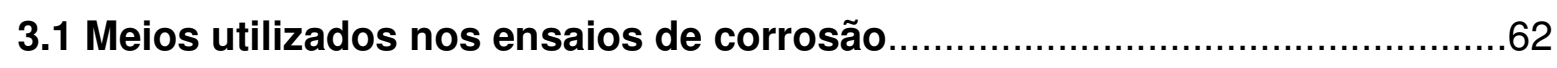

3.2 Confecção e preparo superficial dos corpos-de-prova (CP)......................65

3.3 Ensaio de imersão em presença de condensado natural e sintético

3.4 Técnicas para caracterização dos produtos de corrosão e morfologia das

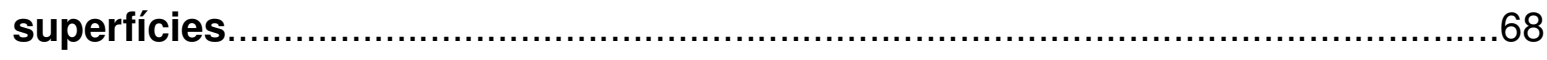

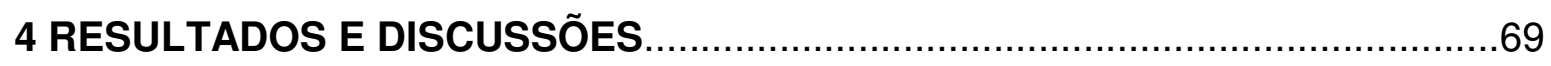


4.1 Análise química das amostras de ligas de ferro fundido .69

4.2 Análise química do condensado natural.

4.3 Caracterização da microestrutura das amostras de ferro fundido. 71

4.4 Ensaios de imersão e caracterização da superfície pós-ensaios por MEV. .76

4.4.1 Ensaio de imersão e caracterização pós-ensaio por microscopia ótica. .84

4.5 Caracterizações dos produtos solúveis após ensaio de imersão presentes nos condensados.

4.6 Avaliações da resistência à corrosão por meio de ensaios eletroquímicos.. .96

5. CONCLUSÕES. 100

6 SUGESTÕES PARA TRABALHOS FUTUROS. 102

APÊNDICE A. 103

APÊNDICE B. 104 


\section{LISTA DE TABELAS}

Página

TABELA 1 - Composição dos gases de exaustão de um motor diesel de chassis leve.

TABELA 2 - Reações de combustão e condensação que acontecem em motores que utilizam o diesel como combustivel

TABELA 3 - Composição do condensado sintético da norma VDA adotado neste estudo. .54

TABELA 4 - Composição química nominal (\% em massa) dos elementos nos ferros fundidos cinzento estudados neste trabalho.

TABELA 5 - Composição do condensado sintético da norma VDA adotado neste estudo. .63

TABELA 6 - Análise química (\% em massa dos elementos) dos ferros fundidos cinzento estudados neste trabalho. 69

TABELA 7 - Composição química do condensado natural coletado na bancada de teste de emissões $(\mathrm{pH}=3,5$ e condutividade $26 \mu \mathrm{S} / \mathrm{cm})$. 70

TABELA 8 - Concentração em ppm, obtido por ICP dos metais dissolvidos no condensado natural durante os ensaios de imersão do material perlítico. .94

TABELA 9 - Concentração em ppm, obtido por ICP dos metais dissolvidos pelo condensado natural durante os ensaios de imersão do material 
bainítico.

TABELA 10 - Concentração em ppm, obtido por ICP dos metais dissolvidos pelo condensado sintético durante os ensaios de imersão para 0 material perlítico. 95

TABELA 11 - Concentração em ppm, obtido por ICP dos metais dissolvidos pelo condensado sintético durante os ensaios de imersão para 0 material bainítico. .95 


\section{LISTA DE FIGURAS}

Página

FIGURA 1 - Circuito básico de EGR em um motor de combustão interna... 21

FIGURA 2 - Observação de corrosão na parte interna de uma camisa de cilindro. Regiões A, B e C, 1-imagens de microscopia eletrônica de varredura (MEV); Regiões A, B e C, 2- imagens de elétrons retro espalhados (BSE); Regiões A, B e C, 3 - imagem da secção transversal. 25

FIGURA 3 - Camisas em ferro fundido finalizadas para montagem no $\mathrm{MCl}$ .28

FIGURA 4 - Detalhe dos componentes de um motor de combustão interna... .29

FIGURA 5 - Sequência de combustão no motor ciclo diesel. 29

FIGURA 6 - Limites de emissões veiculares para NOx na Europa. 31

FIGURA 7 - Esquema de rompimento do filme de óleo na parede das camisas de cilindros 34

FIGURA 8 - Classificação da grafita segundo ASTM-271. 40

FIGURA 9 - Eutético fosforoso - "Steadita" - Presente no ferro fundido cinzento perlítico. Ataque químico com nital 2 \%. Imagem por microscopia óptica 
FIGURA 10 - Microestrutura esquemática do ferro fundido cinzento perlítico. A decomposição parcial da perlita adjacente aos flocos de grafita produz regiões de ferrita circundando os flocos de perlita. .43

FIGURA 11 - Ferro fundido cinzento perlítico. Ataque da matriz com Nital $3 \%$. Grafita tipo A em forma de flocos distribuídos em uma matriz com $20 \%$ de ferrita livre e $80 \%$ de perlita

FIGURA 12 - Ferro fundido cinzento perlítico. Ataque da matriz com Nital $3 \%$. Grafita tipo A em forma de flocos distribuídos em uma matriz com $20 \%$ de ferrita livre e $80 \%$ de perlita. . .44

FIGURA 13 - Diagrama esquemático CCT ("continous cooling transformation"). 46

FIGURA 14 - Ferro Fundido Bainítico. Ataque da matriz com Nital 5\%. Grafita tipo A e B com tamanhos de 5 a 8 distribuídas em uma matriz bainítica com perlita fina.

FIGURA 15 - Ferro Fundido Bainítico. Ataque da matriz com Nital $5 \%$. Grafita tipo A e B com tamanhos de 5 a 8 distribuídas em uma matriz bainítica com perlita fina.

FIGURA 16 - Mecanismo de grafitização em ferro fundido na presença de $\mathrm{H}_{2} \mathrm{~S}$. 49

FIGURA 17 - Diagrama de Equilíbrio potencial versus pH, para o sistema FerroÁgua, a $25^{\circ} \mathrm{C}$ 56

FIGURA 18 - Diagrama de Equilibrio dinâmico de Pourbaix. Sistema Ferro-Água, com os limites de corrosão, passivação e imunidade. 
FIGURA 19 - Microestrutura do ferro fundido perlítico. Grafita: Forma I; distribuição $\mathrm{B}$; tamanho 4 - 5 - (A) sem ataque e (B) após ataque com Nital 3 $\%$ 61

FIGURA 20 - Microestrutura do ferro fundido bainítico (A) sem ataque e (B) após ataque com Nital $3 \%$

FIGURA 21 - Fluxograma das etapas da metodologia adotada neste estudo, desde a preparação dos materiais e meios, até os ensaios realizados 62

FIGURA 22 - Bancada de medição e controle de emissões da empresa Mahle Metal Leve. .64

FIGURA 23 - Esquema do corpo-de-prova para os ensaios de corrosão. 65

FIGURA 24 - Potenciostato / Galvanostato Modelo 273A da EG\&G Instruments Princeton Applied Research conectado a um computador e controlado pelo programa Corrosion Measurement \& Analysis Software (352/252) 67

FIGURA 25 - Célula eletroquímica com eletrodo de calomelano saturado como eletrodo de referencia de $\mathrm{Ag} / \mathrm{AgCl}$ e um contra eletrodo de platina .67

FIGURA $26 \quad-\quad$ Microscópio eletrônico de varredura Quanta 600FEI 68

FIGURA 27 - Micrografias por MEV do ferro fundido cinzento perlítico após ataque com nital $3 \%$. (a) Imagem de elétrons retro espalhados (BSE) e (b) de elétrons 
secundários (SE), mostrando 0 relevo da superfície da

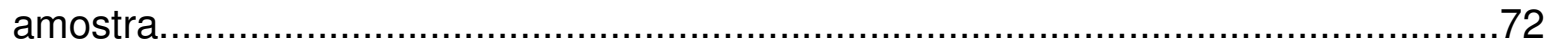

FIGURA 28 - Micrografias por MEV do ferro fundido cinzento bainítico após ataque com nital 3 \%. (a) Imagem de elétrons retro espalhados (BSE) e (b) de elétrons secundários (SE), mostrando 0 relevo da superfície da amostra .73

FIGURA 29 - Grafitas no material perlítico do tipo A distribuídas de forma uniforme com orientação irregular e lamelas finas, tipo $D$ com segregação interdendrítica e com orientação irregular e E com segregação interdendrítica orientada e veios finos. .74

FIGURA 30 - Grafitas no material bainítico do tipo A distribuídas de forma uniforme com orientação irregular e lamelas finas e tipo B com agrupação em rosetas com orientação irregular, centro formado por grafita fina e as bordas com grafitas grossas, ambas distribuídas em toda matriz. 74

FIGURA 31 - Análise semi-quantitativa por espectroscopia de energia dispersiva (EDS) de fases no material perlítico. Espectro 1 - Eutético fosforoso (Steadita); Espectro 2 - Sulfeto de Manganês .75

FIGURA 32 - Análise semi-quantitativa por espectroscopia de energia dispersiva (EDS) de fases no material bainítico. Espectro 1 - Carboneto de molibdênio; Espectro 2 - Sulfeto de Manganês. 76

FIGURA 33 - Micrografias por MEV do ferro fundido perlítico após ataque corrosivo em condensado sintético. Imagens de elétrons retro espalhados (BSE) (a) antes da imersão; (b) após 2 horas; (c) após 20 horas; (d) após 60 horas de imersão. 
FIGURA 34 - Micrografias por MEV do ferro fundido cinzento bainítico antes e após imersão em condensado sintético. Imagens de elétrons retro espalhados (BSE). (a) Antes da imersão; e após (b) 2 horas; (c) 20 horas; (d) 60 horas de imersão. .78

FIGURA 35 - Análise semi-quantitativa por espectroscopia de energia dispersiva (EDS) das várias fases no ferro fundido perlítico indicadas por números na figura 29. Espectro 1 - "Steadita"; espectro 2 - Grafita; espectro 3 - Sulfeto de Manganês .79

FIGURA 36 - Análise semi-quantitativa por espectroscopia de energia dispersiva (EDS) de várias fases no ferro fundido bainítico, indicadas por números na figura 31. Espectro 1 - Carboneto de Molibdênio; espectro 2 - Sulfeto de Manganês; espectro 3 - "Steadita'; espectro 4 - Grafita. 80

FIGURA 37 - Micrografia por MEV mostrando imagem de elétrons secundários (SE) da superfície do ferro fundido perlítico após $120 \mathrm{~h}$ de imersão e espectros EDS das áreas marcadas na micrografia como (1) correspondendo à grafita remanescente e (2) região da matriz com ataque

corrosivo. .82

FIGURA 38 - Micrografia por MEV mostrando imagem de elétrons secundários (SE) da superfície do ferro fundido bainítico após $120 \mathrm{~h}$ de imersão. O espectro EDS 1 corresponde à grafita remanescente e o espectro 2 a região da matriz com ataque corrosivo. 83

FIGURA 39 - Imagem por Microscopia Ótica da superfície das amostras do ferro fundido perlítico após ensaio de imersão no condensado natural. (a) $2 \mathrm{~h}$, (b) $5 \mathrm{~h}$ (c) $16 \mathrm{~h}$ e (d) $120 \mathrm{~h}$ de imersão. 
FIGURA 40 - Imagem por Microscopia Ótica da superfície das amostras do ferro fundido perlítico após ensaio de imersão no condensado sintético. (a) 2 h, (b) 5 h (c) $16 \mathrm{~h}$ e (d) $120 \mathrm{~h}$ de imersão.

FIGURA 41 - Imagens por Microscopia Ótica da superfície das amostras do ferro fundido perlítico após ensaio de imersão no condensado natural. (a) h, (b) 5 h, (c) 16 h e (d) $120 \mathrm{~h}$ de imersão. .86

FIGURA 42 - Imagens por Microscopia Ótica da superfície das amostras do ferro fundido bainítico após ensaio de imersão no condensado sintético. (a) $2 \mathrm{~h}$ e (b) $5 \mathrm{~h}$ $\begin{array}{llllllll}\text { de imersão, } & \text { (c) } 16 \quad \mathrm{~h} & \mathrm{e} & \text { (d) } 120 & \mathrm{~h} & \mathrm{de}\end{array}$ imersão. .87

FIGURA 43 - Imagens das secções transversais das amostras do ferro fundido bainítico após ensaio de imersão no condensado natural. (a) 2 h, (b) 5 h(c) 16 h e (d) $120 \mathrm{~h}$ de imersão. .88

FIGURA 44 - Imagens das secções transversais das amostras do ferro fundido perlítico após ensaio de imersão no condensado sintético. (a) 2 h, (b) 5 h, (c) 16 h e (d) $120 \mathrm{~h}$ de imersão. .89

FIGURA 45 - Imagens das secções transversais das amostras do ferro fundido bainítico após ensaio de imersão no condensado natural. (a) 2 h, (b) 5 h, (c) 16 e (d) $120 \mathrm{~h}$ de imersão. .90

FIGURA 46 - Imagens das secções transversais das amostras do ferro fundido bainítico após ensaio de imersão no condensado sintético. (a) $2 \mathrm{~h}$, (b) $5 \mathrm{~h}$, (c) $16 \mathrm{~h}$ e (d) $120 \mathrm{~h}$ de imersão. 91

FIGURA 47 - Comparação da penetração do ataque corrosivo por observação da secção transversal do ferro fundido perlítico (a) e do ferro fundido bainítico (b), em 
solução de condensado sintético, após $120 \mathrm{~h}$ de ensaio de imersão. 92

FIGURA 48 - Evolução da concentração do silício em solução para os materiais de microestrutura perlítica e bainítica em meio dos condensados natural e sintético .93

FIGURA 49 - Evolução da concentração do ferro em solução para os materiais de microestrutura perlítica e bainítica em meio dos condensados natural e sintético 94

FIGURA 50 - Diagramas de Nyquist para os ferros fundidos perlítico e bainítico, após $2 \mathrm{~h}$ de imersão, em meio de condensado sintético diluído. 97

FIGURA 51 - Diagramas de Nyquist para os ferros fundidos de microestrutura perlítica e bainítica, após 2 h de imersão, em meio de solução de cloreto de sódio 0,1 molar. 98

FIGURA 52 - Curvas de polarização, anódicas e catódicas, obtidas em solução de cloreto de sódio $0,1 \mathrm{~mol} \mathrm{~L}^{-1}$ para os ferros fundidos perlítico e bainítico .98

FIGURA 53 - Análise quantitativa por imagem proporção de áreas de fase grafita em relação à área da matriz. (a) Material perlítico sem quantificação; (b) Material perlítico com quantificação; (c) Material bainítico sem quantificação; (d) Material bainítico com quantificação 


\section{LISTA DE SIGLAS E ABREVIATURAS}

ARLA

BSE

CCT

CONAMA

CP

C/S

DOC

DPF

EDS

EGR

EIE

EPA

EUA

FC

HC

IC

ICP

$\mathrm{MCl}$

MEV

MML

MO

PROCONVE

SE

PM
Agente Redutor Liquido de NOx Automotivo.

Elétrons retro espalhados

'Continous Cooling Transformation' - Curva de Resfriamento Contínuo

Conselho Nacional de Meio Ambiente

Corpos de Prova

Carbono e Enxofre

Catalisadores de Oxidação

Filtros de Partículas

Espectroscopia de Energia Dispersiva

"Exhaust Gas Recirculation" - Recirculação dos Gases de Exaustão

Espectroscopia de Impedância Eletroquímica

"Environmental Protection Agency" - Agência de proteção ambiental

Estados Unidos da América

Ferro Fundido Cinzento

Hidrocarbonetos

Cromatografo Liquido lônico

Espectrômetro de Emissão de Plasma

Motor de Combustão Interna

Microscopia Eletrônica de Varredura

Mahle Metal Leve S/A

Microscopia Ótica

Programa de Controle da Poluição do Ar por Veículos

Automotores.

Elétrons secundários

Material Particulado 
SCR "Selective Catalytic Reduction"- Catalisador de Redução Seletiva UE União Europeia

ULSD "Ultra-Low Sulfur Diesel" - Teor de Enxofre ultra-baixo no Diesel

VDA "Verband der Automobilindustrie"- Associação da Indústria Automotiva 


\section{LISTA DE SIMBOLOS E FORMULAS QUÍMICAS}

\begin{tabular}{|c|c|}
\hline $\mathrm{Ag} / \mathrm{AgCl}$ & Prata/Cloreto de prata \\
\hline Al-Si & Alumínio - Silício \\
\hline $\mathrm{CH}_{4}$ & Metano \\
\hline $\mathrm{CO}_{2}$ & Dióxido de Carbono \\
\hline $\mathrm{CO}$ & Monóxido de Carbono \\
\hline $\mathrm{Fe}$ & Ferro \\
\hline $\mathrm{Fe}^{+2}$ & Óxido de ferro II \\
\hline $\mathrm{Fe}_{(\mathrm{s})}$ & Ferro Metálico \\
\hline $\mathrm{Fe}_{3} \mathrm{C}$ & Carboneto de Ferro \\
\hline $\mathrm{Fe}_{3} \mathrm{O}_{4}$ & Magnetita \\
\hline $\mathrm{Fe}_{3} \mathrm{P}$ & Fosfeto de ferro \\
\hline $\mathrm{Fe}_{2} \mathrm{O}_{3} \cdot \mathrm{H}_{2} \mathrm{O}$ & Óxido de Ferro-Monohidratado \\
\hline $\mathrm{Fe}(\mathrm{OH})_{2}$ & Hidróxido Ferroso \\
\hline $\mathrm{Fe}(\mathrm{OH})_{3}$ & Hidróxido de ferro III \\
\hline $\mathrm{H}_{2}$ & Hidrogênio \\
\hline $\mathrm{H}_{2} \mathrm{~S}$ & Ácido Sulfídrico \\
\hline $\mathrm{H}_{2} \mathrm{SO}_{4}$ & Ácido Sulfúrico \\
\hline $\mathbf{N}_{2}$ & Nitrogênio \\
\hline $\mathrm{NaCl}$ & Cloreto de Sódio \\
\hline $\mathrm{NO}_{\mathrm{x}}$ & Óxido de Nitrogênio \\
\hline $\mathrm{O}_{2}$ & Oxigênio \\
\hline $\mathrm{OH}^{-}$ & Íon hidroxila \\
\hline $\mathrm{SO}_{2}$ & Dióxido de Enxofre \\
\hline $\mathrm{SO}_{3}$ & Trióxido de Enxofre \\
\hline$\alpha-F e O O H$ & Goethita \\
\hline$\beta-\mathrm{FeOOH}$ & Akaganeita \\
\hline y-FeOOH & Lepidocrocita \\
\hline
\end{tabular}




\section{INTRODUÇÃO}

As evoluções tecnológicas e o aperfeiçoamento dos motores de combustão interna $(\mathrm{MCl})$ são constantes. A grande maioria visa melhorar 0 desempenho destes motores, bem como reduzir o consumo de combustível e a emissão de gases poluentes, adequando-se às exigências impostas pelos órgãos ambientais e as demandas dos consumidores por automóveis mais econômicos e duráveis.

Os $\mathrm{MCl}$ transformam energia térmica em trabalho mecânico utilizando combustíveis de origem fóssil, particularmente combustíveis provenientes do petróleo, gasolina e diesel e, portanto, uma fonte finita de energia. Além do problema de escassez dos combustíveis, o uso destes em grande escala, provoca a degradação do meio ambiente. Perante este panorama a sociedade impôs desafios para melhorar o uso dos recursos naturais e de qualidade de vida, com o desenvolvimento de combustíveis renováveis, de maior autonomia e potência, e veículos com maior espaço interno e redução ou eliminação de emissões de poluentes. Atualmente, a maior preocupação das indústrias é desenvolver motores a combustão que sejam cada vez menos poluentes, uma vez que a preocupação com a preservação do meio ambiente é essencial. Uma das técnicas que vem sendo utilizada, principalmente em motores produzidos na Europa e Estados Unidos, é a EGR, (termo em inglês para "Exhaust Gas Recirculation"). Esta técnica tem como principal objetivo reduzir o óxido de nitrogênio $\left(\mathrm{NO}_{\mathrm{x}}\right)$, o dióxido de enxofre $\mathrm{SO}_{2}$, o trióxido de enxofre $\mathrm{SO}_{3}$, e outros gases emitidos por motores que circulam com diesel como combustível. Um dos gases mais poluentes e abundantes produzidos por motores movidos a diesel é o óxido de nitrogênio.

A utilização da válvula EGR causa a redução no índice de emissão deste gás de $5 \mathrm{~g} / \mathrm{kWh}$ para $0,4 \mathrm{~g} / \mathrm{kWh}$ (BARBIERI, 2010). A técnica EGR é conhecida e utilizada desde 1970. Foi abdicada para aplicações em motores a diesel durante muitos anos devido ao fato que os combustíveis antigos apresentavam altos teores de enxofre. A combustão, destes induzia à formação de gases, como $\mathrm{SO}_{2}$ e $\mathrm{SO}_{3}$, em grande quantidade, os quais se associavam ao 
vapor de água, levando à formação do ácido sulfúrico $\left(\mathrm{H}_{2} \mathrm{SO}_{4}\right)$. Os vapores, juntamente com o ácido, eram recirculados, resultando em danos nos componentes do motor. O circuito básico de EGR apresentado na figura 1 mostra que uma parte do gás que deveria ir para o escape, retorna para o sistema de admissão, passando por uma válvula de EGR. O objetivo da utilização deste recurso é o de atender o limite de emissões, previsto para entrar em vigor na Europa em 2014, o chamado nível EURO VI, que deve ser menor que 0,5 g/kWh (BARBIERI, 2010).

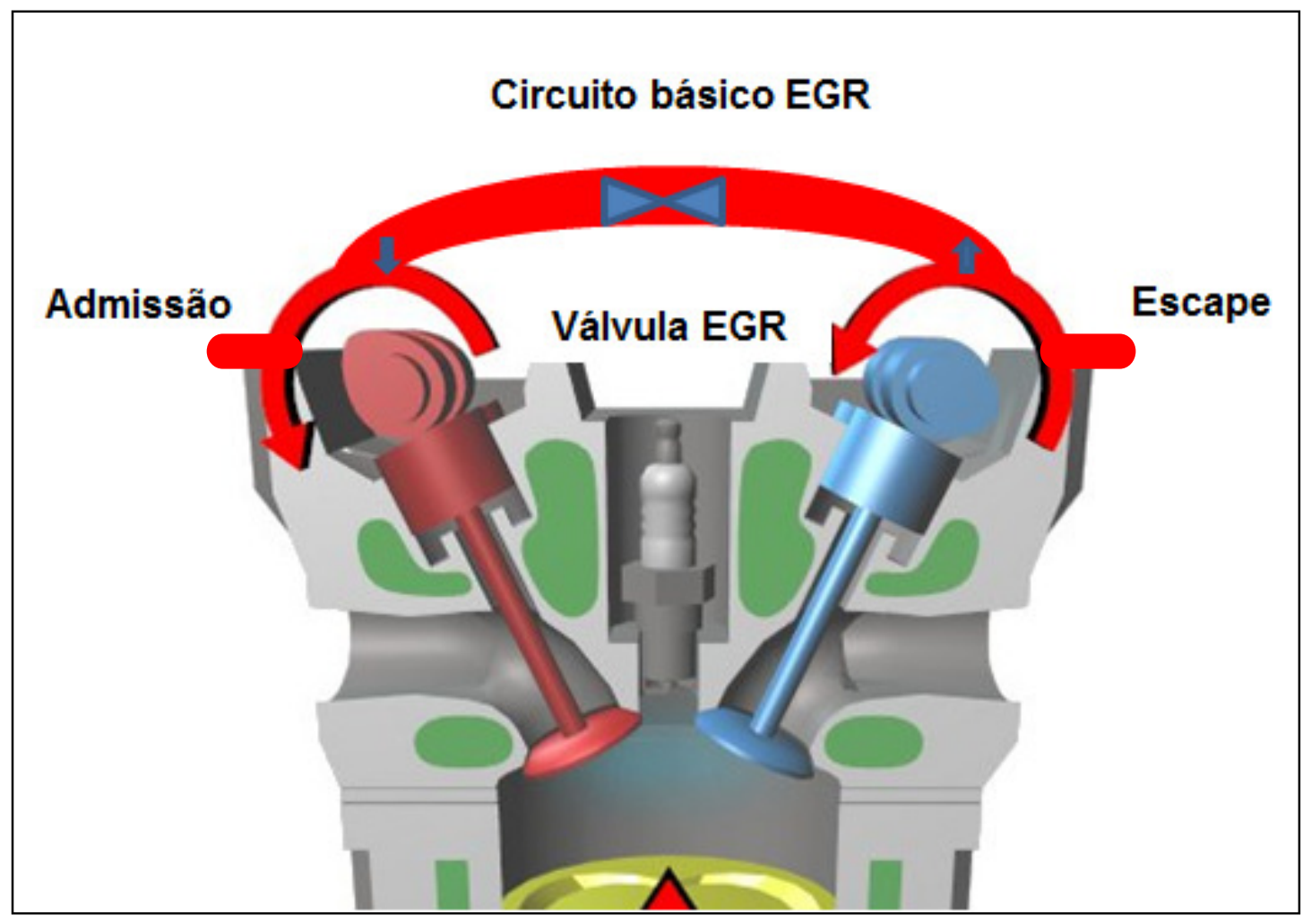

Figura 1 - Circuito básico de EGR em um motor de combustão interna.

A condensação dos gases de combustão em geral acontece nos sistemas de exaustão dos veículos. No entanto, com a inserção da tecnologia de recirculação dos gases de escape, as condensações vêm sendo promovidas também dentro da câmara de combustão dos veículos. Isto porque a entrada de gás frio na câmara, onde as temperaturas podem variar entre $300 \stackrel{\circ}{\mathrm{C}}$ a mais de $1000 \stackrel{\circ}{\mathrm{C}}$ provoca a condensação dos gases de combustão. A recirculação de parte do gás que iria para o sistema de exaustão é diluída na carga de ar/combustível. Em consequencia, uma mistura diluída queima mais lentamente, resultando em uma redução de quase $300^{\circ} \mathrm{C}$ na temperatura da câmara de combustão. 
A combustão ideal deveria gerar somente calor, água $\left(\mathrm{H}_{2} \mathrm{O}\right)$, gás nitrogênio $\left(\mathrm{N}_{2}\right)$ e dióxido de carbono $\left(\mathrm{CO}_{2}\right)$, porém, na prática, a emissão dos motores diesel contém centenas de compostos químicos, que são emitidos na fase gasosa, e na fase sólida, como fuligem. Foi identificado um total de 445 substâncias na emissão dos veículos a diesel. Os principais produtos da exaustão do diesel são dióxido de carbono, oxigênio, nitrogênio, vapor de água, monóxido de carbono, óxido de enxofre, óxido de nitrogênio, material particulado e compostos orgânicos, dos quais os hidrocarbonetos fazem parte. Uma representação média da composição dos gases de exaustão de um motor diesel leve é apresentada na tabela 1 (HIRAI, 2009).

Tabela 1 - Composição dos gases de exaustão de um motor diesel de chassis leve.

\begin{tabular}{cc}
\hline Substância & Concentração (\% em massa) \\
\hline Nitrogênio & 75,2 \\
Oxigênio & 15 \\
Dióxido de carbono & 7,1 \\
Vapor de água & 2,6 \\
Monóxido de carbono & 0,03 \\
Óxidos de nitrogênio & 0,03 \\
Dióxido de enxofre & 0,01 \\
Material particulado & 0,006 \\
Hidrogênio & 0,002 \\
Aldeídos & 0,0014 \\
Hidrocarbonetos & 0,0007 \\
Sulfatos & 0,00016 \\
Amônia & 0,00005 \\
\hline
\end{tabular}

Fonte - HIRAI, 2009.

Durante a combustão do óleo diesel, devido às condições específicas do ambiente na câmara, os gases corrosivos formados, que contêm enxofre e nitrogênio, reagem com a umidade, levando à formação de compostos corrosivos. Especialmente o ácido sulfúrico e o ácido nítrico, conforme indicado nas reações de combustão e condensação apresentadas na tabela 2. Análise específica de compostos orgânicos ácidos em gases de exaustão de veículos movidos a diesel 
permitiu identificar a presença de ácido acético e ácido fórmico, sendo o primeiro mais abundante que o segundo. A concentração dos ácidos orgânicos medida foi 2,3 ppb de ácido fórmico e 5,5 ppb de ácido acético (KAWAMURA et al. 2000).

Tabela 2 - Reações de combustão e condensação que acontecem em motores que utilizam o diesel como combustivel.

$$
\begin{array}{cc}
\begin{array}{c}
\text { Reações do enxofre com oxigênio - Combustão } \\
\text { Reações em temperaturas }>1000 \stackrel{\mathrm{S}}{\circ} \mathrm{C}
\end{array} & 2 \mathrm{O}_{2} \rightarrow \mathrm{SO}_{2} \\
\text { Combustão } & \mathrm{O}_{2} \rightarrow 2 \mathrm{SO}_{3} \\
\text { Reações de Condensação } & \mathrm{SO}_{3}+\mathrm{H}_{2} \mathrm{O} \rightarrow \mathrm{H}_{2} \mathrm{SO}_{4} \\
& \mathrm{SO}_{2}+\mathrm{H}_{2} \mathrm{O} \rightarrow \mathrm{H}_{2} \mathrm{SO}_{3} \\
\mathrm{NO}+\mathrm{H}_{2} \mathrm{O} \rightarrow \mathrm{HNO}_{3}
\end{array}
$$

Fonte - VON, 2004.

O uso de combustível com alterações nas concentrações de contaminantes, no caso, teor de enxofre acima dos limites permitidos, traz inúmeros prejuízos financeiros e ambientais, uma vez que causa a corrosão de peças essenciais ao bom funcionamento do motor do veículo. Este desgaste pode ocasionar problemas, como aumento no consumo de combustível, perda no rendimento, entupimentos e falhas na bomba de combustível.

O diesel limpo refere-se principalmente ao nível de enxofre, embora várias outras propriedades do combustível, como o número de cetano, lubricidade, aromáticos e densidade, também sejam importantes para aperfeiçoar a combustão e permitir a aplicação das tecnologias avançadas. A diminuição nos teores de enxofre no diesel causa redução proporcional na formação de poluentes primários, como o $\mathrm{SO}_{2}, \mathrm{SO}_{3}$, e materiais particulados (AMBROZIN e KURI, 2009).

Em virtude das diferentes legislações de controle de combustível e emissões, em alguns países e ou regiões, é de se esperar que estes apresentem um condensado com composição diferente. Desde 2003, na união Europeia (UE) e desde 2007 nos Estados Unidos da Améica (EUA), quase todo o combustível diesel disponível apresenta teor de enxofre ultrabaixo (ULSD termo em inglês para Ultra Low Sulfur Diesel). O limite máximo de teor de enxofre definido para a UE é de 10 ppm e para os EUA, de 15 ppm. 
Devido ao baixo teor de enxofre no combustível, o gás de escape e os seus condensados são menos agressivos em comparação com os dos veículos que utilizam diesel com teores de enxofre elevados. Nas áreas rurais da Argentina e do Brasil o óleo diesel contém entre (500 e 2000) ppm de enxofre, e nas regiões metropolitanas, este se limita a (50 ou 500) ppm. Desde 2002, a China também tem limitado o teor de enxofre no diesel a 2000 ppm com limites reduzidos a 500 ppm para determinadas cidades. Os gases de escape condensados a partir desses combustíveis são significativamente mais agressivos, especialmente devido ao maior teor de ácido sulfúrico formado. Com relação ao teor de cloreto, elemento altamente agressivo do ponto de vista de corrosão, o valor tipicamente encontrado no combustível diesel é de 10 ppm. Devido ao teor de cloreto ser muito baixo, a concentração encontrada nos condensados de exaustão também é muito baixa, com valores típicos inferiores a 80 ppm, (HARTMANN e NUETZEL, 2012). O apêndice A mostra um mapa com a situação global para o teor de enxofre no diesel.

Sabe-se que o condensado produzido pelo veículo possui uma relação direta com o combustível utilizado. Investigações sobre o comportamento de desgaste e corrosão de componentes de motores mostram que o aumento no teor de enxofre para cerca de 350 ppm causa problemas significativos de corrosão, conforme ilustrado na figura 2.

A camisa analisada apresentou corrosão em toda a sua extensão; no entanto, em níveis diferentes. Observa-se que na região $B$ o ataque foi mais intenso. Este efeito pode ser explicado pela variação de temperatura na parede do cilindro. A região central pode apresentar valores que variam entre (100 e 140) ${ }^{\circ} \mathrm{C}$ (REJOWSKI, 2012). Esta faixa de temperatura favorece a condensação do vapor de água presente na câmara de combustão. O apêndice B ilustra uma simulação numérica típica de elementos finitos, onde se obteve um modelo do gradiente de temperatura nos quatro cilindros do motor. Ao mesmo tempo, a presença de gases como o $\mathrm{SO}_{2} \mathrm{e} \mathrm{SO}_{3}$ promove a elevação do ponto de orvalho entre (14 e 42) ${ }^{\circ} \mathrm{C}$. A temperatura do ponto de orvalho é sensível à pressão, pois esta afeta a pressão parcial de vapor de água do ar. Ao se elevar a pressão do ar, a temperatura do ponto de orvalho se eleva, e caso ultrapasse a temperatura do ar, ocorrerá condensação (VON, 2004). Embora o controle do teor de enxofre e do sistema eletrônico de dosagem das válvulas de EGR seja rígido, alguns componentes 
dentro da câmara de combustão ainda sofrem problemas de corrosão, principalmente os materiais de camisas de cilindros que são produzidos na sua grande maioria em ligas de ferro fundido, e que são suscetíveis a ataques corrosivos.

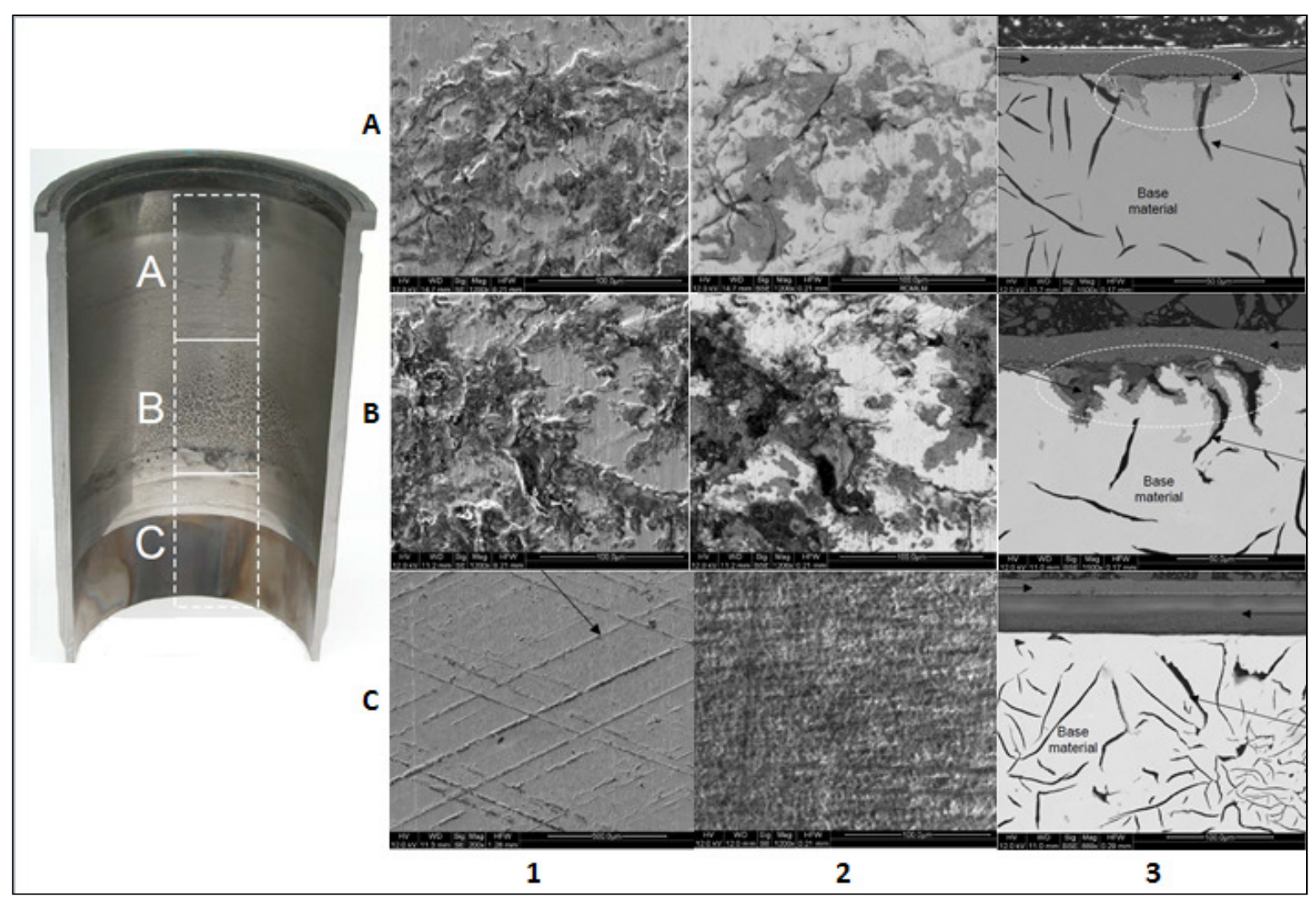

Figura 2 - Observação de corrosão na parte interna de uma camisa de cilindro. Regiões A, B e C, 1 - imagens de microscopia eletrônica de varredura (MEV); Regiões A, B e C, 2 imagens de elétrons retroespalhados (BSE); Regiões $A, B$ e C, 3 - imagem da secção transversal (BRAGHETTO, 2007).

O presente trabalho investiga e compara a resistência à corrosão de duas ligas de ferro fundido que apresentam diferentes microestruturas, particularmente perlítica e bainítica com diferentes composições químicas que são utilizadas na fabricação das camisas dos cilindros automotivos.

Uma revisão da literatura realizada neste estudo mostrou que os trabalhos voltados especificamente para o estudo dos problemas de corrosão em camisas de ferro fundido são praticamente inexistentes. Diante disto se fez necessário entender o mecanismo de corrosão apresentado por estes materiais e suas principais diferenças quando em contato com uma solução corrosiva. 


\subsection{OBJETIVO}

O objetivo deste trabalho de pesquisa é estudar a resistência frente à corrosão de duas ligas de ferro fundido em meios de condensado natural do sistema automotivo com válvula EGR integrada e que utiliza o diesel como combustível e em condensado sintético, normalmente usado para simular o condensado natural. Além disso, avaliar e comparar o mecanismo de corrosão dos dois tipos de ferro fundido investigados, um de estrutura perlítica e o outro de estrutura bainítica.

Apesar de ter sido realizada uma revisão criteriosa, não foi encontrada publicações na literatura sobre o comportamento frente à corrosão dos ferros fundidos estudados em meio de condensado natural, o que justifica a necessidade deste estudo, uma vez que as ligas de ferro fundido são muito usadas em camisas de cilindros de diversos motores veiculares de combustão interna. 


\section{REVISÃO DA LITERATURA}

\subsection{Camisas de Cilindros Automotivos}

A camisa de cilindro é um elemento que compõe a estrutura do bloco do motor. Em um sistema fechado favorece o processo de transformação de energia e troca térmica do calor gerado na combustão, com resfriamento com água ou ar, os quais circulam ao redor da camisa (HEYWOOD 1988). O material escolhido para confecção de uma camisa de cilindro depende da aplicação do motor, garantindo que as condições impostas pelo bloco do motor sejam respeitadas. As características de resistência ao desgaste e rigidez do sistema são requisitos essenciais. Deste modo, algumas ligas de ferro fundido são preferíveis a outras por suas microestruturas apresentarem parte do carbono livre em forma de grafita ou cementita $\left(\mathrm{Fe}_{3} \mathrm{C}\right)$.

As camisas de cilindros automotivos, em sua grande maioria, são produzidas em ligas de ferro fundido e utilizadas em motores movidos a diesel, conhecidos como motores de grande potência. O processo de fabricação das camisas consiste em vazar o metal líquido em um molde dotado de movimento de rotação, de modo que a força centrífuga origine uma pressão, além da gravidade. Esta obriga o metal líquido $a$ ir de encontro às paredes do molde onde se solidifica por meio de vazamento do material em uma centrifuga. Os elevados fluxos de escoamento de calor permitem reduzir os tempos de solidificação, originando melhores propriedades mecânicas.

As propriedades mais importantes dos materiais de camisa são peso específico, microestrutura, dureza, resistência à tração, resistência à fadiga, condutividade térmica, coeficiente de expansão térmica, módulo de elasticidade e resistência à corrosão. No entanto, características como alta resistência ao desgaste e rigidez também são essenciais.

A combinação de composição química e microestrutura apropriada tem se mostrado, por várias décadas, uma solução efetiva e de baixo custo para os ferros fundidos. Na figura 3 apresentam-se algumas camisas em ferro fundido, finalizadas para fornecimento e montagem no motor de combustão interna $(\mathrm{MCl})$. 


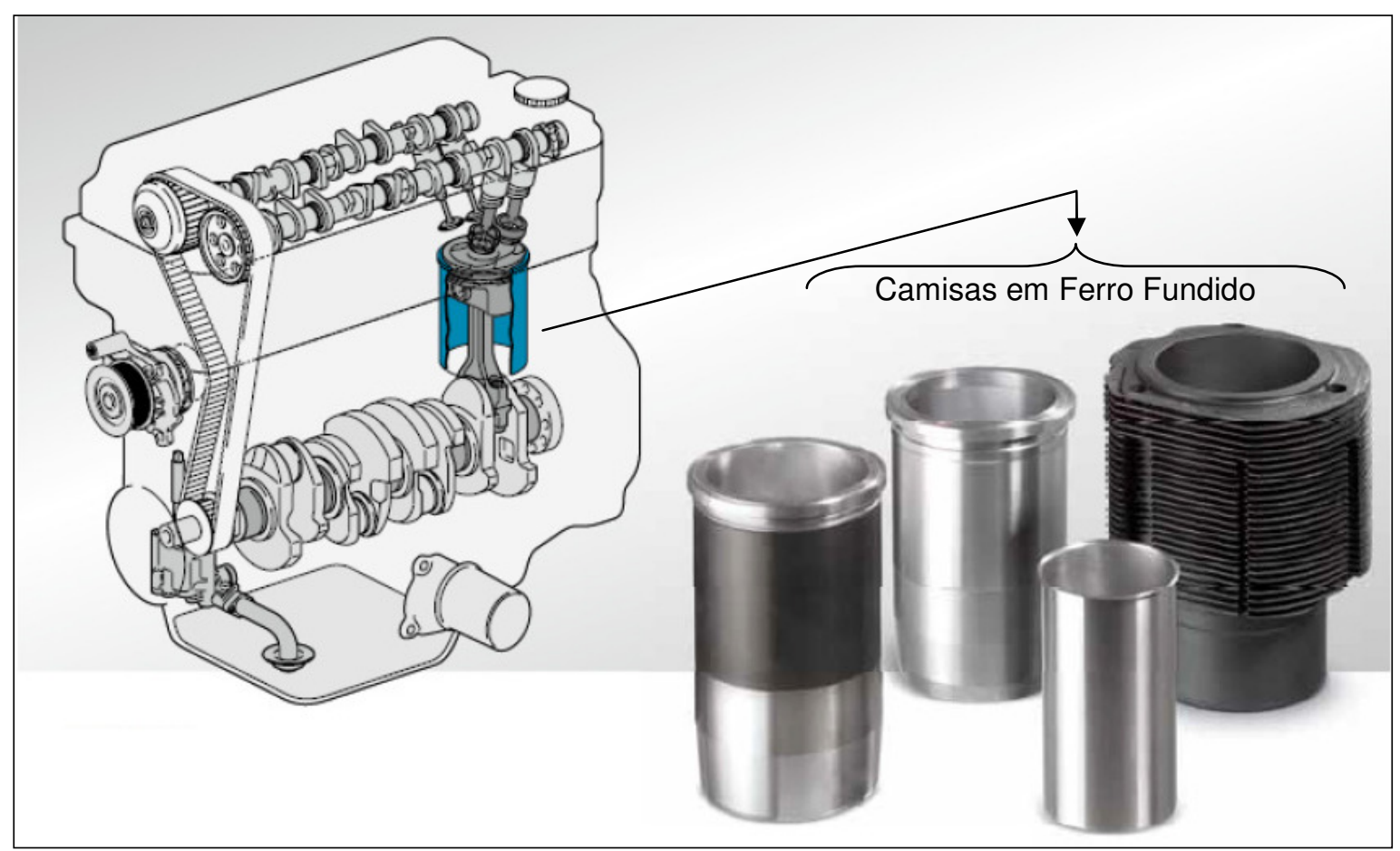

Figura 3 - Camisas em ferro fundido finalizadas para montagem no MCI (MAHLE, 2012).

\subsection{Motores de Combustão}

Os motores de combustão interna (MCl) têm como objetivo transformar energia térmica em energia mecânica, diretamente utilizável. Após a mistura de combustível e ar ser comprimida na câmara de combustão de cada cilindro, iniciase uma queima. Esta libera uma força contra a cabeça do pistão, forçando este a deslocar-se na direção do virabrequim, ou eixo de manivelas. A biela é o elemento de ligação entre o pistão e o virabrequim. Este transmite a força atuante na cabeça do mesmo para o virabrequim, fazendo com que este gire e converta o movimento retilíneo alternado dos pistões, em movimento rotativo do virabrequim. A força que atua na cabeça dos pistões é resultante da expansão dos gases de combustão. A figura 4 apresenta o detalhe do sistema em um dos cilindros de um MCI (MAHLE, 2012). Os motores de combustão interna podem ser classificados em: motor ciclo gasolina, no qual a mistura (gasolina/ar) se inflama através de uma centelha elétrica, ocasionando a queima da mistura e a expansão dos gases de combustão; motor ciclo álcool, no qual a mistura (álcool/ar) se inflama através de uma centelha elétrica, ocasionando a queima da mistura e a expansão dos gases de combustão; motor ciclo diesel, em que somente o ar é comprimido, sendo o combustível injetado no interior do cilindro, quando a compressão do ar está próxima do seu ponto máximo, e a elevação de temperatura e pressão no 
interior do cilindro inflama o óleo diesel na câmara de combustão. A figura 5 apresenta a sequência de combustão do motor ciclo diesel.

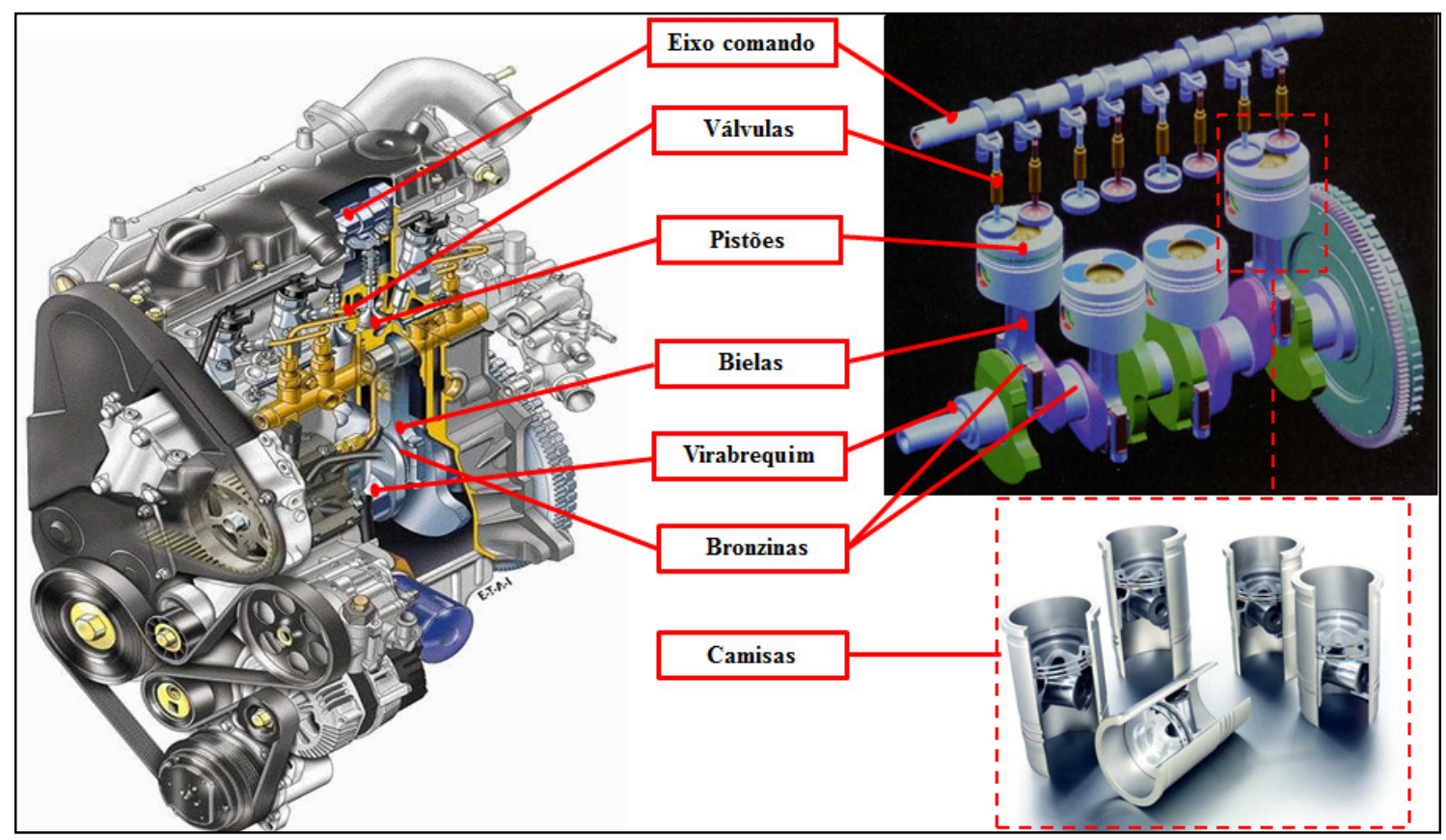

Figura 4 - Detalhe dos componentes de um motor de combustão interna (MAHLE, 2012).

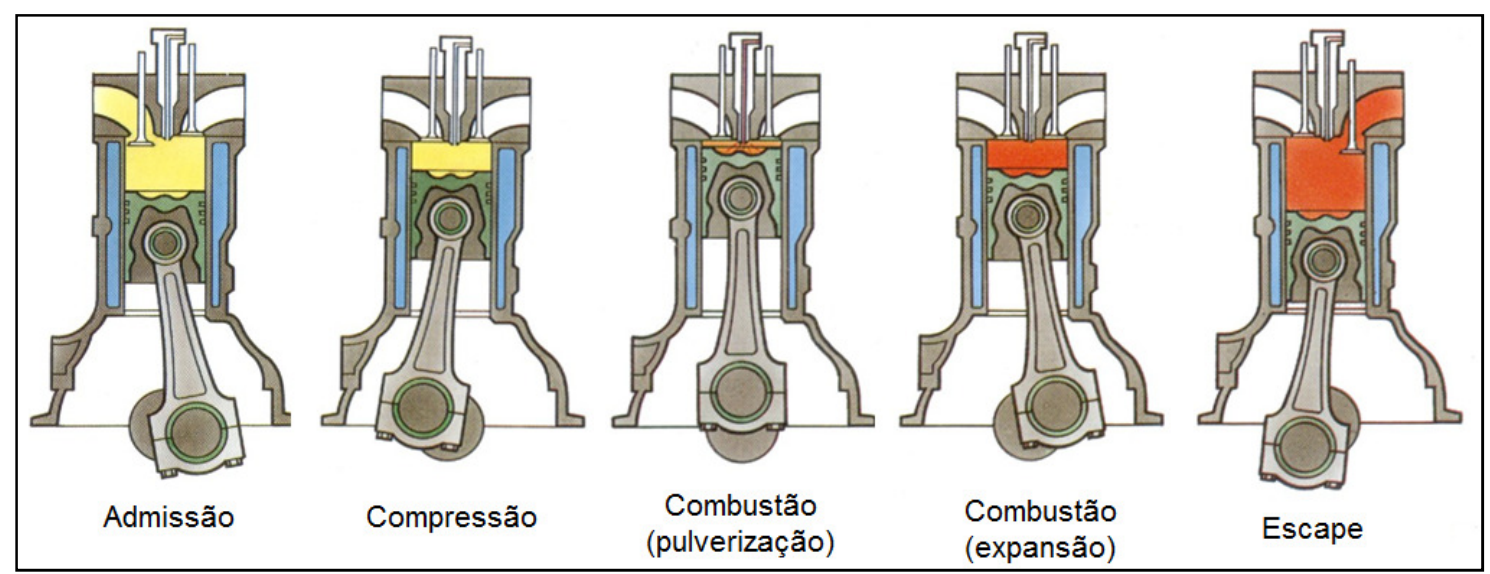

Figura 5 - Sequência de combustão no motor ciclo diesel (MAHLE, 2012).

Os motores movidos a diesel são normalmente maiores e mais pesados que os motores ciclo gasolina e álcool, sendo consequentemente mais utilizados em veículos utilitários, como caminhões. A principal diferença entre a combustão dos motores ciclo diesel em relação aos motores de ciclo gasolina e álcool é o fato de o primeiro operam sempre com excesso de ar proporcionando uma combustão mais completa e, portanto, emissão de teores de $\mathrm{CO}$ muito mais baixos (HEYWOOD, 1988). Devido à alta eficiência e flexibilidade com a excepcional durabilidade dos motores movidos a diesel, existe uma tendência mundial para a 
utilização destes nas indústrias automobilísticas em carros de passeio. É comum um motor a diesel utilizado em veículos de carga pesada ter um tempo de vida superior a um milhão de quilômetros. Isto significa $45 \%$ a mais de rendimento em comparação aos outros motores de combustão interna. As vantagens oferecidas por um motor movido a diesel justificam sua utilização, apesar dos problemas relacionados a emissões (FERREIRA et al., 2008 e BRAUN, 2003).

\subsection{Reduções de Emissões}

Todos os produtos da combustão, no caso, gases nocivos ao homem e ao meio ambiente, podem ser entendidos como emissões. Os veículos automotores são fontes bastante significativas nas emissões de poluentes do ar.

Segundo BRAUN (2003) os efeitos tóxicos agudos dos gases de exaustão automotiva são conhecidos desde o advento das máquinas de combustão interna. Essas máquinas liberavam quantidades suficientes de monóxido de carbono (CO) que causavam a morte por intoxicação, quando em ambientes fechados. Por esse motivo, a emissão de $\mathrm{CO}$, foi uma das primeiras regulamentações praticadas em vários países. Atualmente, segundo a EPA (termo em inglês para, "Environmental Protection Agency"), os principais poluentes de emissões veiculares são: óxido de nitrogênio (NOx), material particulado (PM), monóxido de carbono (CO) e hidrocarbonetos $(\mathrm{HC})$.

A operação em condições oxidantes dos motores a diesel contribui para uma boa economia de combustível e, comparativamente aos motores à gasolina, resulta em uma menor produção de $\mathrm{CO}_{2}$, num processo de combustão que opera em temperaturas mais baixas. Consequentemente, menor quantidade de $\mathrm{NO}_{x}, \mathrm{CO}$ e hidrocarbonetos $(\mathrm{HC})$ são produzidos.

As emissões veiculares estão padronizadas de formas diferentes no mundo. Tais normas estabelecem limites específicos para a emissão de NOx (óxido de nitrogênio), um dos gases mais poluentes e tóxicos emitidos. Alguns padrões mais rigorosos exigem a utilização do sistema SCR, (termo em inglês para "Selective Catalytic Reduction"), tecnologia que requer a utilização de um reagente químico chamado ARLA 32, (agente redutor líquido de NOx automotivo).

$\mathrm{Na}$ Europa, o primeiro padrão de emissões estabelecido foi o EURO 0 que entrou em vigor em 1990, com limites de NOx de $14,4 \mathrm{~g} / \mathrm{kWh}$. O último padrão, que entrou em vigor em 2013, foi o EURO VI que tem um limite de NOx de 
0,4 g/kWh. A figura 6 apresenta a evolução do controle de emissões de NOx para veículos na Europa, (BRIDI et. al., 2012)

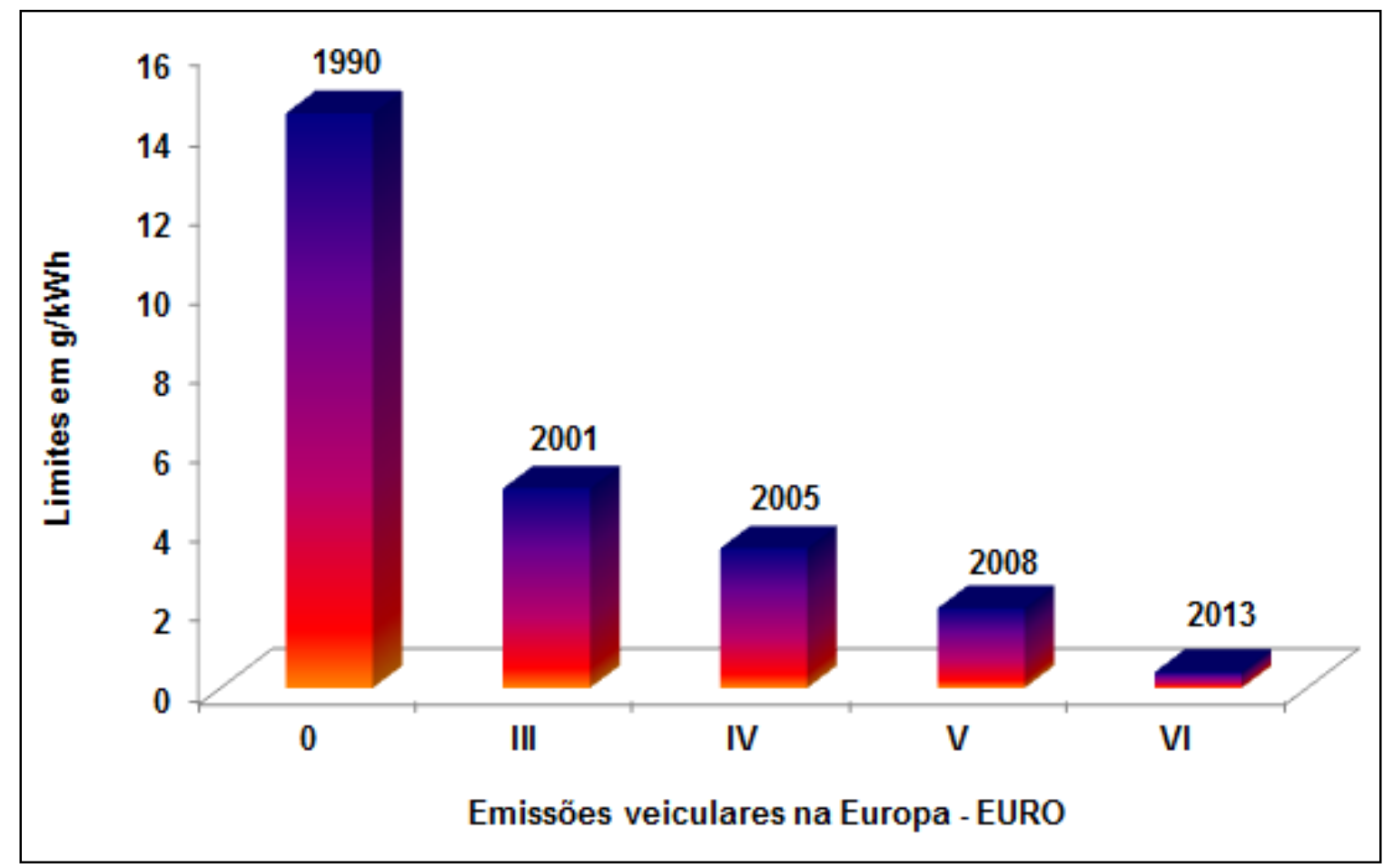

Figura 6 - Limites de emissões veiculares para NOx na Europa. Fonte e adaptação de (BRIDI et. al., 2012).

No Brasil, existe a tendência a se seguir os limites da legislação imposta na Europa e nos Estados Unidos. Para isso, o CONAMA (Conselho Nacional de Meio Ambiente), que tem a responsabilidade de estabelecer padrões e métodos ambientais em todo território nacional, estabeleceu o PROCONVE (Programa de Controle da Poluição do Ar por Veículos Automotores), em nível nacional. Esse programa inclui a fiscalização da fumaça preta em veículos a diesel e os gases emitidos. A fase atual é a P-7, equivalente ao EURO V. Até a fase P-5 do PROCONVE, apenas se estabelecia pequenas melhorias nas tecnologias dos motores para se atingir os níveis de emissões definidos. Porém, para atender a Fase P-7, foram necessários equipamentos de pós-tratamento dos gases de escapamento, como catalisadores de oxidação (DOC), catalisadores de redução seletiva (SCR), filtros de partículas (DPF) e sistemas de recirculação dos gases de escape (EGR). A recirculação do gás do escape (EGR) é um processo que diminui as temperaturas na câmara de combustão com o objetivo de reduzir as emissões. O processo EGR consiste em diluir a carga de ar/combustível com pequenas quantidades de gás do escape. Como o gás do escape possui pouco oxigênio, 
não suporta a combustão. Em consequência, uma mistura diluída queima mais lentamente, resultando em uma redução de quase $300{ }^{\circ} \mathrm{C}$ na temperatura da câmara de combustão. $O$ centro do sistema de recirculação do gás do escape é a válvula EGR, que controla o fluxo dos gases da combustão até o coletor de admissão.

A EPA aconselha a substituição dos motores mais antigos por modernos com sistema EGR integrado, onde a economia de combustível poderá ser da ordem de $40 \%$. Um motor moderno também evita imobilizações com avarias e apresenta uma menor necessidade de intervenções, tendo assim custos menores com manutenção. Entretanto, cada uma das tecnologias estabelecidas para redução de emissões deve estar associada à redução drástica dos teores de enxofre no combustível, visando evitar efeitos contrários aos desejados, ou até mesmo, danos aos sistemas de forma irreversível.

\subsection{Teor de Enxofre no Diesel}

O enxofre no combustível é extremamente indesejável para o meio ambiente, e também para os motores a diesel, uma vez que durante a combustão, o trióxido de enxofre, ao se combinar com água, forma o ácido sulfúrico, que corrói partes metálicas do motor. Se a concentração de enxofre no combustível for elevada, as emissões de materiais primários como $\mathrm{SO}_{2}$ e $\mathrm{SO}_{3}$ podem induzir grandes prejuízos à saúde humana e aos componentes de motor.

OLIVEIRA e BERTAZZOLI (2011) relatam em seu estudo que o diesel apresenta características que dependem do processo de fabricação e da destinação do uso. A corrosividade do diesel é diretamente proporcional aos teores de água, enxofre e sedimentos com isso o teor máximo de água está limitado a $0,05 \%$ e o de enxofre a 500 ppm para o diesel comum de uso metropolitano. Nos países desenvolvidos, os teores de enxofre no diesel são muito baixos. No Japão, o teor máximo de enxofre no diesel é de 10 ppm. Em países europeus, desde 1996 já havia diesel sendo comercializado possuindo aproximadamente 50 ppm de enxofre. Em 2005 todo o diesel comercializado na União Européia passou a ter concentração máxima de enxofre de 50 ppm. Nos Estados Unidos, tais valores de concentração já haviam sido atingidos em 1993. Atualmente, os padrões americanos são da ordem de 15 ppm. O diesel limpo refere-se principalmente ao nível de enxofre, embora várias outras propriedades 
do combustível, como o número de cetano, lubricidade, aromáticos e densidade, também sejam importantes para aperfeiçoar a combustão e permitir a aplicação das tecnologias avançadas. Mesmo sem os benefícios advindos das novas tecnologias de controle, a redução do enxofre no combustível já propicia benefícios ambientais. A utilização de combustíveis limpos, alternativos ou convencionais, é apenas um meio de viabilizar as tecnologias avançadas para o motor e os sistemas de pós-tratamento dos gases para que os benefícios mais significativos resultem da associação de combustível limpo com motores de baixa emissão. Por outro lado, as suas propriedades positivas não são imunes aos desvios de regulagem da combustão do motor, o que exige tecnologias também avançadas para garantir a baixa emissão (SCHNAKENBERG e BUGARSKI, 2002).

Nos motores pesados, as novas tecnologias potencializam importantes reduções de emissões, mas que podem se perder com o uso do veículo em decorrência de desvios na regulagem do motor. Desta forma, pode-se afirmar que os combustíveis limpos são imprescindíveis, mas não suficientes para assegurar a baixa emissão de poluentes e a adequada qualidade ambiental.

A adulteração do diesel é um problema que deve ser enfrentado com rigor. A adição de álcool, solventes, óleos vegetais, querosene e até mesmo a adição de água, são as fraudes mais comuns. $O$ uso do combustível adulterado traz inúmeros prejuízos financeiros e ambientais, uma vez que corrói peças essenciais ao bom funcionamento do motor do veículo, podendo ocasionar problemas como aumento no consumo de combustível, perda no rendimento, entupimentos e falhas na bomba de combustível. Com o uso de combustível adulterado, os veículos podem apresentar, ainda, aparecimento de borra no tanque (biomassa), entupimento de filtro de combustível, corrosão e aumento das emissões de poluentes.

Diversos testes de motores são realizados utilizando-se ciclos de condensação com diesel como combustível e variação no teor de enxofre, que pode chegar até 2000 ppm. O principal objetivo destes testes é o de simular as situações enfrentadas pelos componentes de motores e, principalmente, a identificação dos problemas de corrosão, além da avaliação dos níveis de emissões.

YAHAGI et al. (1986) identificaram em seu estudo que o ácido sulfúrico, 
formado pela presença de enxofre no diesel, pode levar à quebra da película de óleo lubrificante presente na parede das camisas de cilindros, e neutralizar os aditivos do óleo, permitindo assim que os ácidos formados na condensação cheguem à superfície da camisa de cilindros e o processo de corrosão seja iniciado. Na figura 7 apresenta-se o esquema de rompimento do filme de óleo pela ação do ácido sulfúrico.

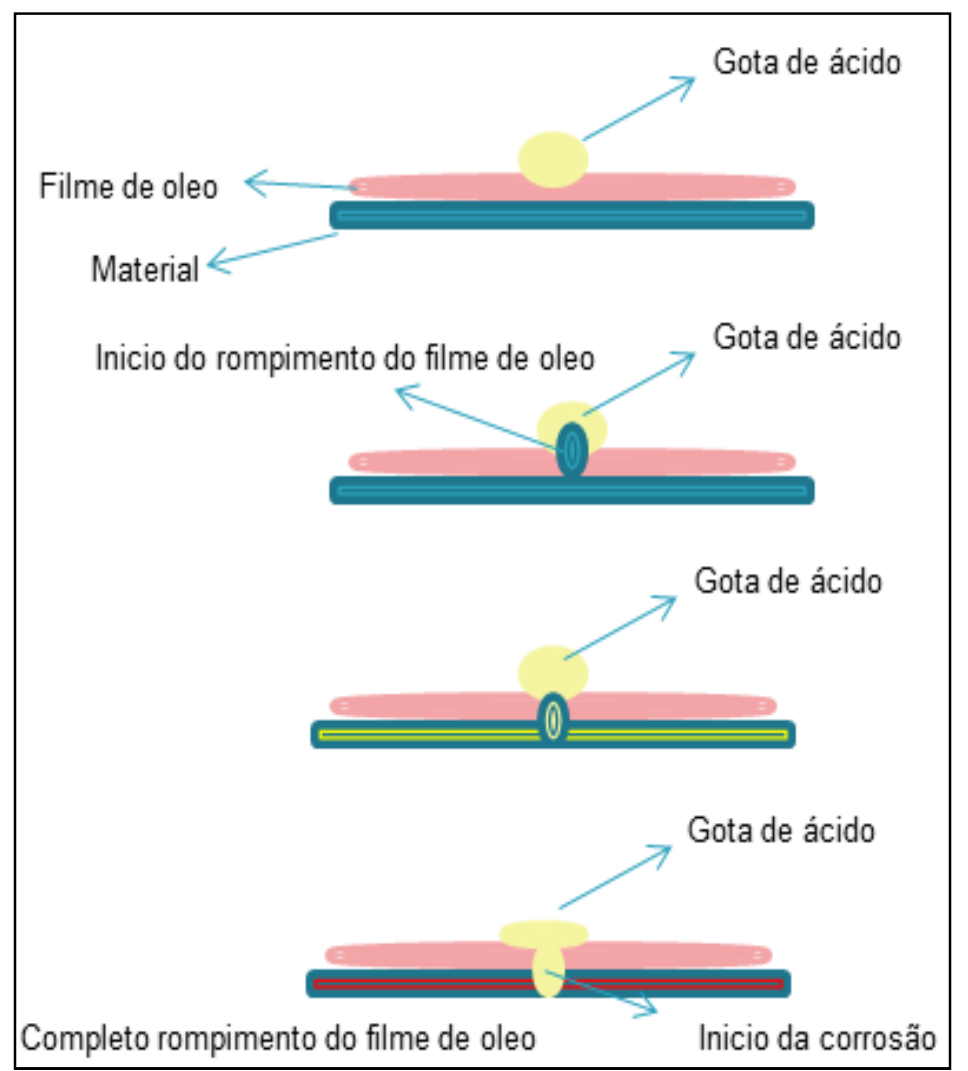

Figura 7 - Esquema de rompimento do filme de óleo na parede das camisas de cilindros. Fonte e adaptação de YAHAGl et al. (1986).

As camisas de cilindros que funcionam em condições corrosivas, têm um perfil de desgaste claro, em diferentes graus. O desgaste corrosivo depende fortemente da temperatura da superfície do local. A variação de temperatura deve favorecer a condensação dos gases e, consequentemente, a formação de ácido sulfúrico.

Na prática, vem sendo observado que a diminuição do teor de enxofre no combustível reduz o desgaste corrosivo nas camisas. No entanto, a utilização de combustíveis limpos, alternativos ou convencionais, é apenas um meio de viabilizar as tecnologias avançadas para os motores e os sistemas de póstratamento dos gases. 
Benefícios mais significativos resultam da associação de combustível limpo com motores de baixa emissão.

\subsection{Ferro Fundido}

As ligas de ferro fundido são materiais de engenharia muito utilizados para a produção de componentes de motores automotivos, como as camisas de cilindros. Estas são, em sua grande maioria, produzidas com este tipo de ligas. A composição química e a microestrutura destas ligas são alteradas conforme a aplicação do motor.

Neste trabalho foi avaliada a resistência à corrosão de duas ligas de ferro fundido cinzento, que apresentam diferentes microestruturas e composições químicas. Essas ligas são utilizadas na fabricação de camisas de cilindros automotivos e são amplamente aplicadas em motores que utilizam o diesel como combustível. Embora todo o trabalho tenha sido desenvolvido utilizando duas ligas de ferro fundido cinzento, uma breve introdução sobre os diversos tipos de ferros fundidos e suas características, será apresentada em seguida.

O termo ferro fundido, como o aço, é usado na identificação de uma grande família de ligas ferrosas. Estas são ligas do sistema ternário $\mathrm{Fe}-\mathrm{C}-\mathrm{Si}$ contendo teores de carbono acima de $2 \%$. A adição de outros elementos de liga a estes materiais é comum para alcançar certas propriedades mecânicas e de resistência à corrosão. Pode-se também alterar as propriedades destes materiais utilizando tratamentos térmicos, (CHIAVERINI, 1988 e BARELLA, 1980).

Os ferros fundidos conseguem combinar o custo baixo de fabricação do material com outras características como, facilidade de fusão, facilidade de usinagem, resistência à corrosão, boa capacidade de amortecimento de vibrações, condutividade térmica, resistência mecânica e possibilidade de obtenção de amplas faixas de dureza. Estas propriedades tornam estes materiais um grupo de ligas com importância fundamental para a indústria, e ampliam o seu emprego em aplicações que eram exclusivas aos aços carbono.

Um tratamento extremamente importante para as ligas de ferro fundido é o térmico, uma vez que garante transformações de fases nos materiais e conseguindo definir uma microestrutura com as características desejadas. Uma das características que pode interferir no tratamento térmico dos materiais é a composição química dos mesmos, levando à formação de diferentes fases e 
alterando a taxa de resfriamento e as condições de fusão (BARELLA, 1980).

Com relação à classificação dos ferros fundidos, seis tipos são apresentados a seguir. Estes podem ser caracterizados pelo tipo de fratura que apresentam após a ruptura e por suas características de microestrutura. (CHIAVERINI, 1988).

a) Ferros fundidos brancos: Apresentam o carbono e o silício como elementos de liga fundamentais. $O$ carbono se apresenta quase que inteiramente na forma combinada de carboneto de ferro, $\left(\mathrm{Fe}_{3} \mathrm{C}\right)$. Este material não apresenta grafita livre em sua microestrutura e a fratura apresenta coloração clara.

b) Ferros fundidos cinzentos: Estes materiais apresentam diferentes tipos e tamanhos de grafite na matriz metálica. A fratura destes apresenta coloração escura. Tem como elementos de liga fundamentais o carbono e o silício e uma estrutura em que, parte significativa do carbono está no estado livre, como grafita lamelar, e outra, no estado combinado, $\left(\mathrm{Fe}_{3} \mathrm{C}\right)$.

C) Ferros fundidos mesclados: A fratura apresenta coloração mista, entre branca e acinzentada. Caracterizados por uma mescla de proporções variáveis de ferro fundido branco e ferro fundido cinzento.

d) Ferros fundidos nodulares: Apresenta o carbono livre na forma de grafita esferoidal, o que confere ao material boa característica de ductilidade.

e) Ferros fundidos maleáveis: Obtidos a partir do ferro fundido branco, mediante um tratamento especial para maleabilizar o material, resultando em uma transformação de praticamente todo o ferro combinado em grafita na forma de nódulos, invés de veios ou lamelas.

f) Ferros fundidos de grafita compactada: Materiais intermediários entre o ferro fundido cinzento e o ferro fundido nodular. Caracterizados pelo fato da grafita apresentar-se em escamas, ou seja, com forma de plaquetas ou estrias. Outras denominações são escamas agregadas e vermiculares. Estes ferros fundidos exigem a adição de elementos especiais, como terras raras, e um elemento adicional, como titânio, que reduz a formação de grafita esferoidal.

Todos estes tipos de ferros fundidos, com exceção do branco, são compostos de uma fase grafítica em uma matriz que pode ser ferrítica, perlítica, bainítica, martensítica temperada, ou uma combinação destas (CARMO et al., 1995). 
Em todas as formas, os ferros fundidos apresentam ductilidade insuficiente para operações de conformação mecânica. Deste modo, componentes como camisas de cilindros de motores, fabricados em ferros fundidos, só podem ser obtidas por processos de fundição.

\subsubsection{Características de composição química, estrutura e resistência à corrosão dos ferros fundidos.}

a) Composição química: Dentre os elementos de liga que podem influenciar na estrutura dos ferros fundidos, o carbono e o silício são os principais. O carbono é que determina a quantidade de grafita que pode ser formada, e o silício é elemento essencialmente grafitizante, favorecendo a decomposição do carboneto de ferro, $\left(\mathrm{Fe}_{3} \mathrm{C}\right)$. Sua presença, independentemente do teor carbono, pode fazer o ferro fundido tender para o cinzento ou para o branco. O manganês, sempre presente, tem efeito oposto ao do silício, isto é, estabiliza a cementita e, assim, contrabalança, a ação grafitizante do silício. Este também é adicionado como dessulfurante, visando reduzir os efeitos deletérios do $S$. O manganês combina-se com o enxofre formando as inclusões de sulfeto de manganês. $\mathrm{Na}$ prática há sempre um excesso de manganês, o qual atua como estabilizador da perlita. Os outros elementos são impurezas, como o fósforo e o enxofre. Estes não têm ação muito significativa do ponto de vista de tendência grafitizante. Apenas o fósforo é um forte estabilizador do carboneto de ferro. Sua principal ação é na estrutura do material, porque forma com o ferro e com o carbono um composto de natureza eutética, carboneto de ferro e fosfeto de ferro, de aparência branca, conhecido como "steadita" (CHIAVERINI, 1988 e CARMO, 1995). Outro ponto importante na definição da composição química de um ferro fundido é a atuação de alguns elementos na formação da microestrutura das ligas. O níquel é um elemento perlitizante e grafitizante, com um leve efeito no aumento na resistência mecânica. O alumínio é um elemento que promove a formação da fase ferrítica, além de ser um forte grafitizante. O molibdênio promove a formação da fase perlita e atua como estabilizador de carboneto. Em teores altos, também aumenta a resistência mecânica do material. $\mathrm{O}$ cromo atua como um estabilizador de carboneto, mas pode prejudicar a grafitização do material. O cobre é um elemento perlitizante e grafitizante. Em teores em torno de 0,5\% aumenta a resistência da matriz por solução sólida, contribuindo para melhorar a resistência mecânica, com 
efeito similar ao níquel. O silicio é fortemente grafitizante sendo utilizado em ferros fundidos com a intenção de evitar formação de cementita e favorecer grafita.

Com relação à influência da composição da liga sobre o comportamento de corrosão, alguns elementos podem desempenhar papel dominante na susceptibilidade de ferros fundidos ao ataque corrosivo. Em geral, os elementos utilizados para melhorar a resistência à corrosão são o silício, o níquel, o cromo, o cobre e o molibdênio. Outros elementos de liga também são por vezes utilizados para aumentar a resistência à corrosão, tais como o vanádio e titânio. O silício é um dos elementos mais importantes na resistência à corrosão dos ferros fundidos. Concentrações deste elemento da ordem de 3 a $14 \%$ aumentam a resistência à corrosão da liga (CHIAVERINI, 1988). O níquel também é um elemento de importância fundamental na resistência à corrosão dos ferros fundidos, devido à formação de um filme de óxido na superficie da liga. Teores de níquel acima de 4 \% e em combinação com o cromo aumentam significativamente a resistência destas ligas. Adições de cromo na ordem de (15 a 30) \% aumentam a resistência à corrosão das ligas, principalmente em soluções de ácido nitrico. O cromo assim como o níquel tende a formar uma camada de óxido na superfície da liga. O cobre em teores baixos, da ordem de $(0,25$ a 1) \%, aumenta a resistência à corrosão dos ferros fundidos em soluções diluídas de ácido acético e ácido sulfúrico $O$ molibdênio é também um elemento usado para aumentar a resistência à corrosão em ambientes com presença de ácido clorídrico. Em teores acima de 1 \%, combinado com altos teores de silício, aumenta significamente à resistência a corrosão dos ferros fundidos (ASM HANDBOOK, 1996).

Diversas composições químicas das ligas de ferro fundido são produzidas, favorecendo as diversas aplicações de motores. Praticamente todos os elementos de liga estão em solução sólida, com a função de estabilizar a formação de carbonetos, com exceção do cromo que pode formar carboneto metálico. Com relação aos precipitados em ferros fundidos, como principais têmse os nitretos de titânio, alumínio, zircônio, carbonetos de ferro, cromo, vanádio, boro, sulfetos de ferro, manganês e fosfetos de ferro e boro (CARMO et al., 1995).

b) Velocidades de resfriamento: Em elevadas velocidades de resfriamento não existe muito tempo para a decomposição da cementita $\left(\mathrm{Fe}_{3} \mathrm{C}\right)$, de modo que, dependendo dos teores de carbono e de silício, ocorre pouca grafitização e há tendência de formação do ferro fundido branco. Com velocidades de resfriamento 
lentas, ocorre a grafitização, e, dependendo do teor de silício, a estrutura será constituída essencialmente de perlita e grafita. Para resfriamentos ainda mais lentos e teores de silício mais elevados, a cementita da perlita pode também se decompor parcialmente, originando uma estrutura constituída de veios de grafita, perlita e ferrita. A velocidade de resfriamento não influi apenas na grafitização, mas também na forma, na distribuição e no tamanho dos veios de grafita, (CARMO et al., 1995).

c) Componentes estruturais dos ferros fundidos. O mais importante é a grafita, decorrente da decomposição da cementita $\left(\mathrm{Fe}_{3} \mathrm{C}\right)$ em $\mathrm{Fe}$ e C, principalmente por ser o elemento que determina as características mecânicas dos ferros fundidos. A razão pela qual os ferros fundidos apresentam propriedades tão distintas das dos aços reside no fato da grafita constituir descontinuidade na estrutura ou na matriz básica do material, interrompendo a uniformidade ou a continuidade desta matriz. As propriedades mecânicas e físicas dos ferros fundidos são governadas pela forma, tamanho, quantidade e distribuição dos flocos de grafita. A Norma ASTM-271 classifica o aspecto e forma de apresentação da grafita em cinco tipos, conforme apresentado na figura 8. A grafita é classificada, segundo suas dimensões, em oito tamanhos, onde o $n=1$ corresponde às maiores dimensões e veios mais longos, e o $n^{\circ} 8$ às dimensões menores. Embora a forma da grafita e a quantidade de carbetos presente nos ferros fundidos sejam características críticas para as propriedades mecânicas dos mesmos, estas variáveis estruturais não têm efeito elevado na resistência à corrosão. A estrutura lamelar da grafita pode reter os produtos de corrosão e diminuir o processo de corrosão. No entanto, em algumas circunstâncias, a grafite atua catodicamente com relação à matriz, acelerarando o ataque corrosivo desta (ASM HANDBOOK, 1996).

d) Estrutura da matriz: As fases comumente encontradas em um ferro fundido são a ferrita, a cementita e a perlita. Para revelar estas fases, que estão presentes na matriz do ferro fundido, um ataque químico deve ser realizado com uma solução de nital 2 \% (ácido nitríco + álcool etilíco). A fase ferrita é conhecida como fase macia, que apresenta baixo teor de carbono. Esta fase, também conhecida como a-Fe, possui uma estrutura cristalina, baixa resistência à tração, e alta ductilidade. A cementita ou carboneto eutético $\left(\mathrm{Fe}_{3} \mathrm{C}\right)$, é um material duro e quebradiço. 


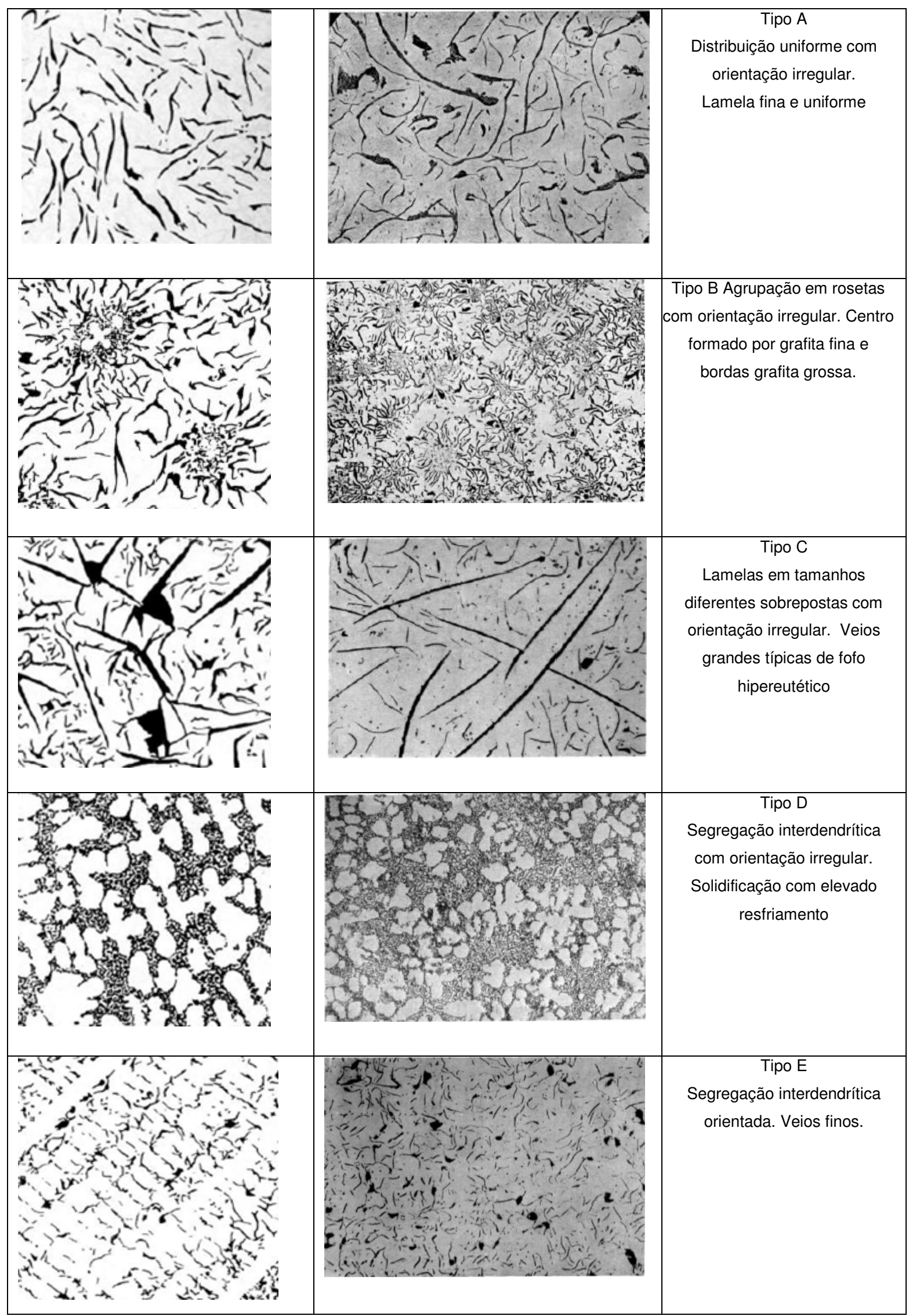

Figura 8 - Classificação da grafita segundo ASTM-271, BARELLA, 1980. 
A perlita é uma fase constituída por lâminas alternadas de ferrita e cementita, sendo que a espessura das lâminas de ferrita é superior à da cementita. Esta última fase fica em relevo depois do ataque com solução de ácido nítrico. A "steadita" é um constituinte de natureza eutética, que compreende partículas de fosfeto de ferro $\left(\mathrm{Fe}_{3} \mathrm{P}\right)$ e carboneto de ferro $\left(\mathrm{Fe}_{3} \mathrm{C}\right)$. Conhecida como fase eutética fosforosa, é comumente encontrada em ferros fundidos com teores de fosforo em níveis superiores a 0,15\%. Para verificar a presença dos cristais eutéticos fosforosos na matriz, deve-se realizar ataque químico com solução de hipobromito de sódio, que revela os fosfetos de ferro. A "steadita" como o carbeto de ferro, pode diminuir as propriedades mecânicas do ferro fundido. A figura 9 mostra a aparência côncava e triangular da steadita (BARELLA, 1980).

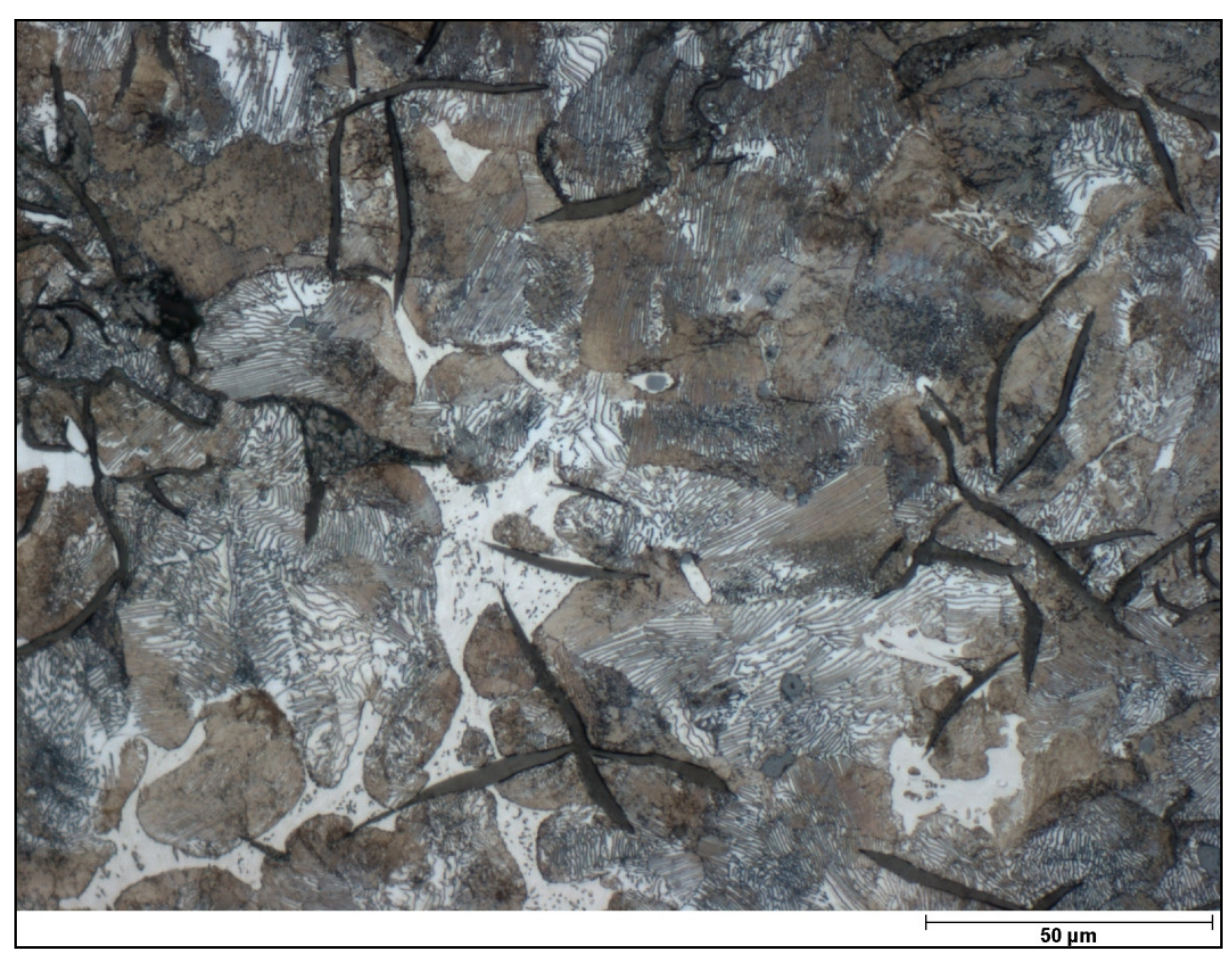

Figura 9 - Eutético fosforoso - "Steadita" - Presente no ferro fundido cinzento perlítico. Ataque químico com nital $2 \%$. Imagem por microscopia óptica.

\subsubsection{Ferro Fundido Cinzento}

Os ferros fundidos cinzentos são designados pela sigla FC na Norma brasileira NBR 6589/1986. Estes apresentam uma parcela relativamente alta de carbono, na forma de grafitas em veios, formando um esqueleto contínuo. $O$ restante do carbono apresenta-se em forma de carboneto eutetóide (BARELLA, 1980). Como em todas as ligas metálicas, existe uma correlação íntima entre as 
propriedades do ferro fundido e a sua estrutura, correlação essa que, no caso particular do ferro fundido cinzento, é mais estreita e mais complexa, tendo em vista a presença de carbono livre na forma de grafita. Portanto, pode se prever, com razoável aproximação, as propriedades dos ferros fundidos cinzentos, em função da sua composição química, teores de carbono grafítico, silício e forma como a grafita se apresenta, bem como a espessura que peças poderem ser produzidas. Deve-se evitar a formação da cementita porque ela é uma fase muito dura e frágil, prejudicando, assim, as características mecânicas do componente. Algumas das aplicações dos ferros fundidos cinzentos são carcaças, mancais, rotores, tambores de freio, blocos de motores, camisas centrifugadas e anéis de pistão. Os ferros fundidos cinzentos são os mais usados, devido a sua fácil fusão e moldagem, boa resistência mecânica, excelente usinabilidade, boa resistência ao desgaste, boa capacidade de amortecimento e resistência à corrosão. A melhor estrutura para o ferro fundido cinzento, quanto à resistência ao desgaste, é a matriz $100 \%$ perlítica e com grafita tipo A. O ferro fundido com menor resistência ao desgaste é o que apresenta matriz ferrítica associada com grafita dentrítica, tipo $\mathrm{D}$ ou $\mathrm{E}$. Na microestrutura, a presença de carbono livre ou grafita é o fator microestrutural predominante, porque quanto maior sua quantidade, mais mole e menos resistente será o material. A matriz metálica dos ferros fundidos cinzentos contém ferrita e perlita. Se a ferrita predominar, a usinabilidade do material será melhor, mas, a resistência mecânica e ao desgaste, serão prejudicadas. Se a perlita for o constituinte predominante na matriz metálica, os ferros fundidos cinzentos correspondentes apresentarão melhor resistência mecânica. Uma matriz contendo ferrita e perlita em proporções praticamente idênticas, proporcionará ao material uma dureza e resistência mecânica intermediárias.

Os ferros fundidos cinzentos apresentam-se dentro de uma faixa de composição química ampla. Os teores de carbono (\% em massa) estão usualmente entre (2,5 e 4,0) \%; os de silício entre $(1,0$ e 3,0) \%; os de manganês entre $(0,2$ e 1,0$) \%$, e os de cromo, entre $(0,2$ e 0,8$) \%$. Os teores máximos de fósforo e enxofre são geralmente menores que $(0,02$ e 1,0) \%, respectivamente. Pode-se ainda adicionar cobre e níquel para elevar as propriedades de resistência mecânica. A introdução de elementos de liga e/ou a aplicação de tratamentos térmicos, modificam a microestrutura da matriz metálica, podendo dar origem a perlita fina, típica da martensita, melhorando as propriedades mecânicas. 


\subsubsection{Ferro Fundido Cinzento Perlítico}

Para a maioria dos ferros fundidos, a grafita existe na forma de flocos, que são normalmente circundados por uma matriz de ferrita ou perlita. A perlita se decompõe apenas parcialmente e a estrutura resultante é uma matriz perlítica, com veios de grafita envolvidos por ferrita. Essa microestrutura é apresentada esquematicamente na figura10 (BARELLA, 1980)

Nos ferros fundidos cinzentos, os teores de carbono podem variar entre $(2,5$ e 4,0$) \%$ e os teores de silício, entre $(1,0$ e 3,0) \%. Um ferro fundido com alto teor de silício, aproximadamente $2 \%$, sofre grafitização tão imediatamente que a cementita $\left(\mathrm{Fe}_{3} \mathrm{C}\right)$ nunca se forma.

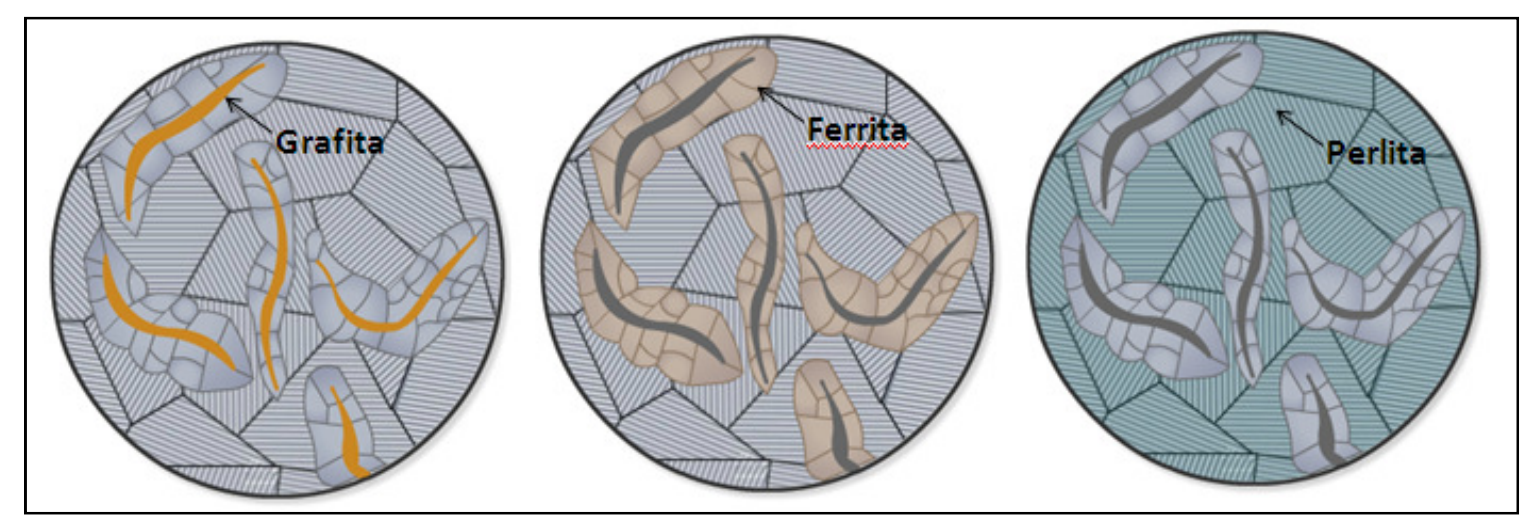

Figura 10 - Microestrutura esquemática do ferro fundido cinzento perlítico. A decomposição parcial da perlita adjacente aos flocos de grafita produz regiões de ferrita circundando os flocos de grafita.

O material será denominado ferro fundido cinzento perlítico, quando na temperatura eutetóide, a austenita se transformar em perlita e a estrutura resultante forem uma matriz perlítica com veios de grafita. As figuras 11 e 12 apresentam a microestrutura do ferro fundido cinzento perlítico, com detalhes da grafita distribuída na matriz. 


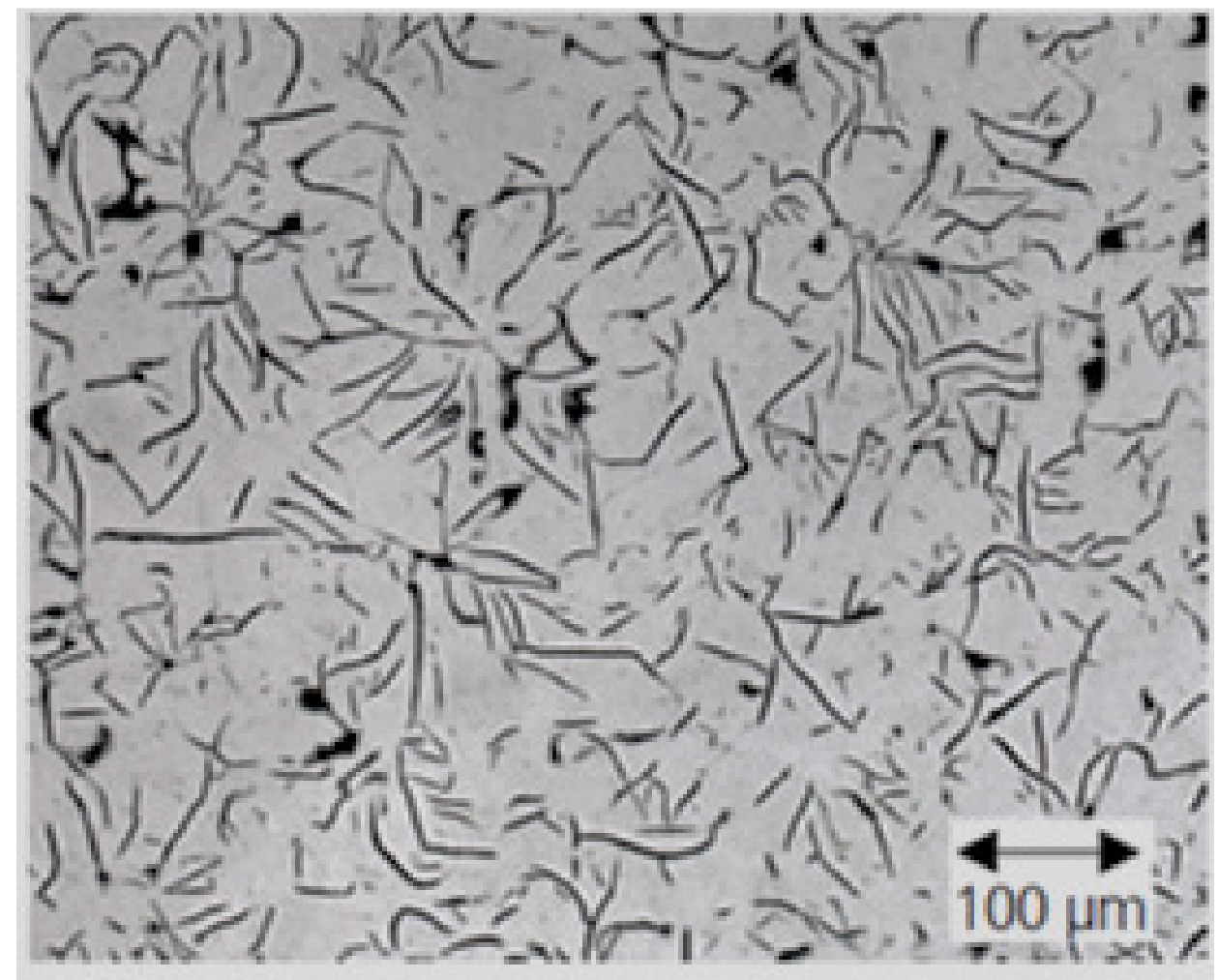

Figura 11 - Ferro Fundido Cinzento Perlítico. Ataque da matriz com Nital $3 \%$. Grafita tipo A em forma de flocos distribuídos em uma matriz com $20 \%$ de ferrita livre e $80 \%$ de perlita.

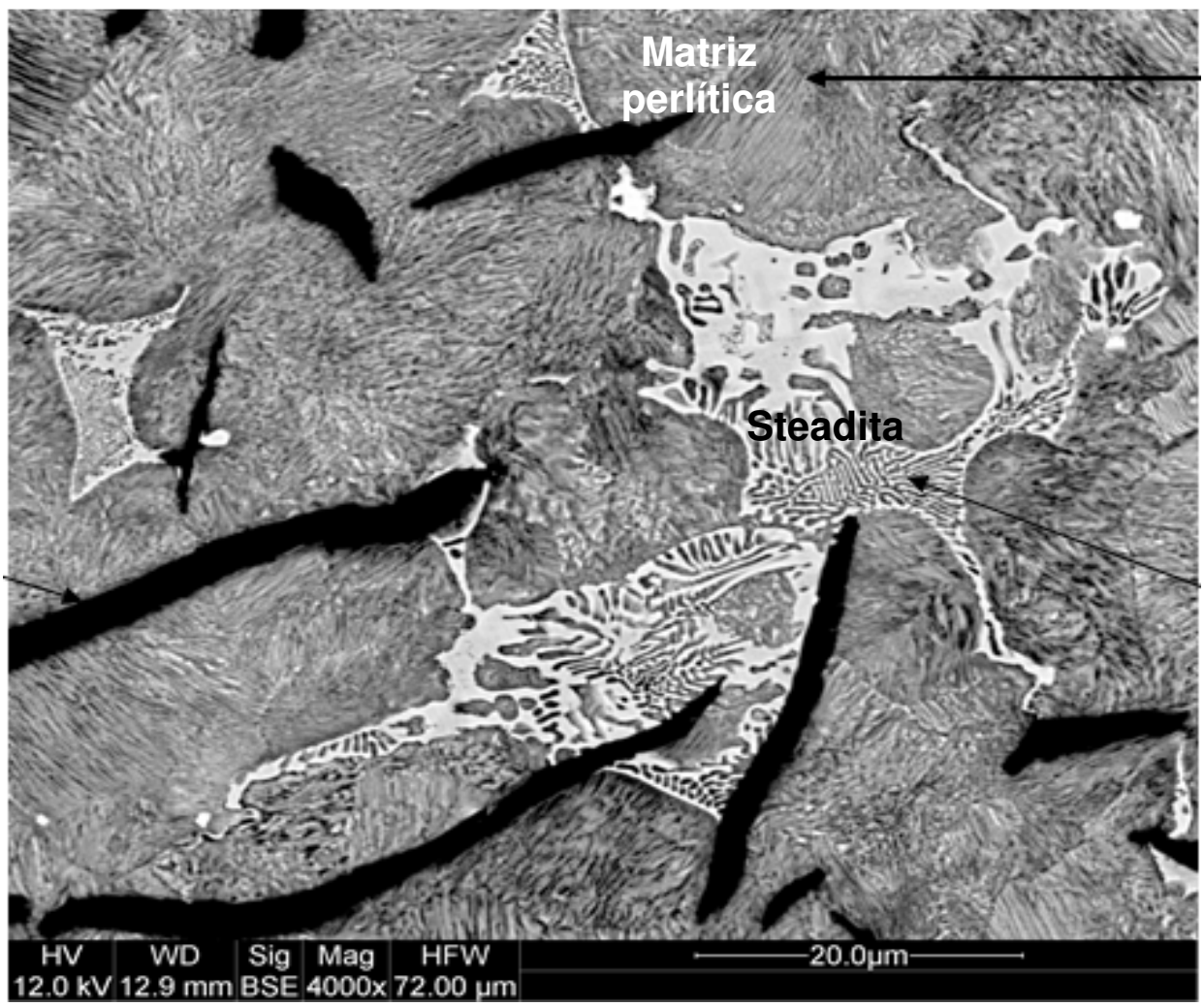

Figura 12 - Ferro Fundido Cinzento Perlítico. Ataque da matriz com Nital $3 \%$. Grafita tipo A em forma de flocos distribuídos em uma matriz com $20 \%$ de ferrita livre e $80 \%$ de perlita. 


\subsubsection{Ferro Fundido Cinzento Bainítico}

A bainita pode ser produzida por tratamento térmico, podendo apresentar dois tipos de estrutura, a bainita superior, de aspecto arborescente composta por uma matriz ferrítica contendo carbonetos, e a bainita inferior, que apresenta um aspecto similar à martensita, esta constituída por agulhas de ferrita e placas finas de carbonetos.

O fenômeno de precipitação de carbonetos é retardado pela presença de elementos de liga como o silício, normalmente presente em elevados teores nos ferros fundidos, em função de sua ação grafitizante. Os carbonetos influenciam as propriedades mecânicas e a fragilização do material (RAMOS, 2008).

Os fenômenos de transformação de fase que ocorrem durante o tratamento de austêmpera, realizados em temperaturas intermediárias, são, em parte, similares aos observados em alguns aços ligados. Microestruturas grosseiras formam-se em temperaturas altas para este tipo de transformação, por exemplo, numa temperatura imediatamente abaixo da temperatura eutetóide. Nessas temperaturas, são produzidas camadas relativamente espessas, tanto da fase ferrita como da fase cementita $\left(\mathrm{Fe}_{3} \mathrm{C}\right)$. Essa microestrutura é denominada perlita grosseira. A formação de lamelas grossas ocorre porque em temperaturas altas as taxas de difusão são muito maiores, de tal modo que os átomos de carbono se difundem ao longo de distâncias relativamente longas. Com a redução da temperatura, a taxa de difusão do carbono diminui, e as camadas se tornam progressivamente mais finas. A estrutura com camadas finas, que é produzida na vizinhança de $540{ }^{\circ} \mathrm{C}$ é denominada perlita fina. Resfriando a austenita até a faixa de temperaturas entre $(200 \text { e } 540)^{\circ} \mathrm{C}$, a cementita cresce na forma de agulhas extremamente finas, ao invés de camadas. A estrutura em forma de agulhas é chamada bainita. A fase ferrita na bainita é, em geral, altamente deformada. A deformação advém das alterações volumétricas provocadas pela transformação e no excesso de carbono preso nos interstícios atômicos, devido ao rápido resfriamento até baixas temperaturas.

Para temperaturas entre aproximadamente (300 e 540$)^{\circ} \mathrm{C}$, a bainita se forma como uma série de tiras paralelas ou agulhas de ferrita, separadas por partículas alongadas da fase cementita. Tal estrutura é denominada bainita superior. Entre $(200$ e 300$){ }^{\circ} \mathrm{C}$, a fase ferrita forma placas finas com partículas 
delgadas de cementita, formando-se no interior dessas placas de ferrita. Essa estrutura é chamada bainita inferior (RAMOS, 2008).

Os ferros fundidos bainíticos são materiais muito utilizados na fabricação de camisas de cilindros automotivos. Estes apresentam em suas ligas, elementos como molibdênio e níquel, que contribuem para o deslocamento para a direita da curva de resfriamento contínuo, nos diagramas CCT, (termo em inglês para 'Continous cooling transformation'), como ilustrado na figura 13, favorecendo assim a transformação da austenita superesfriada em bainita bruta de resfriamento. Estes diagramas mostram a transformação de fase do material em função da taxa de resfriamento. Comparando a bainita bruta de resfriamento com a austenita, pode-se dizer que a austenita não é uma microestrutura estável em temperatura ambiente e, mesmo se fosse estável, a adição de elementos de liga não seria possível nos materiais austenitícos para atender as aplicações onde as demandas de resistência ao desgaste são intensas (CARMO, 1995).

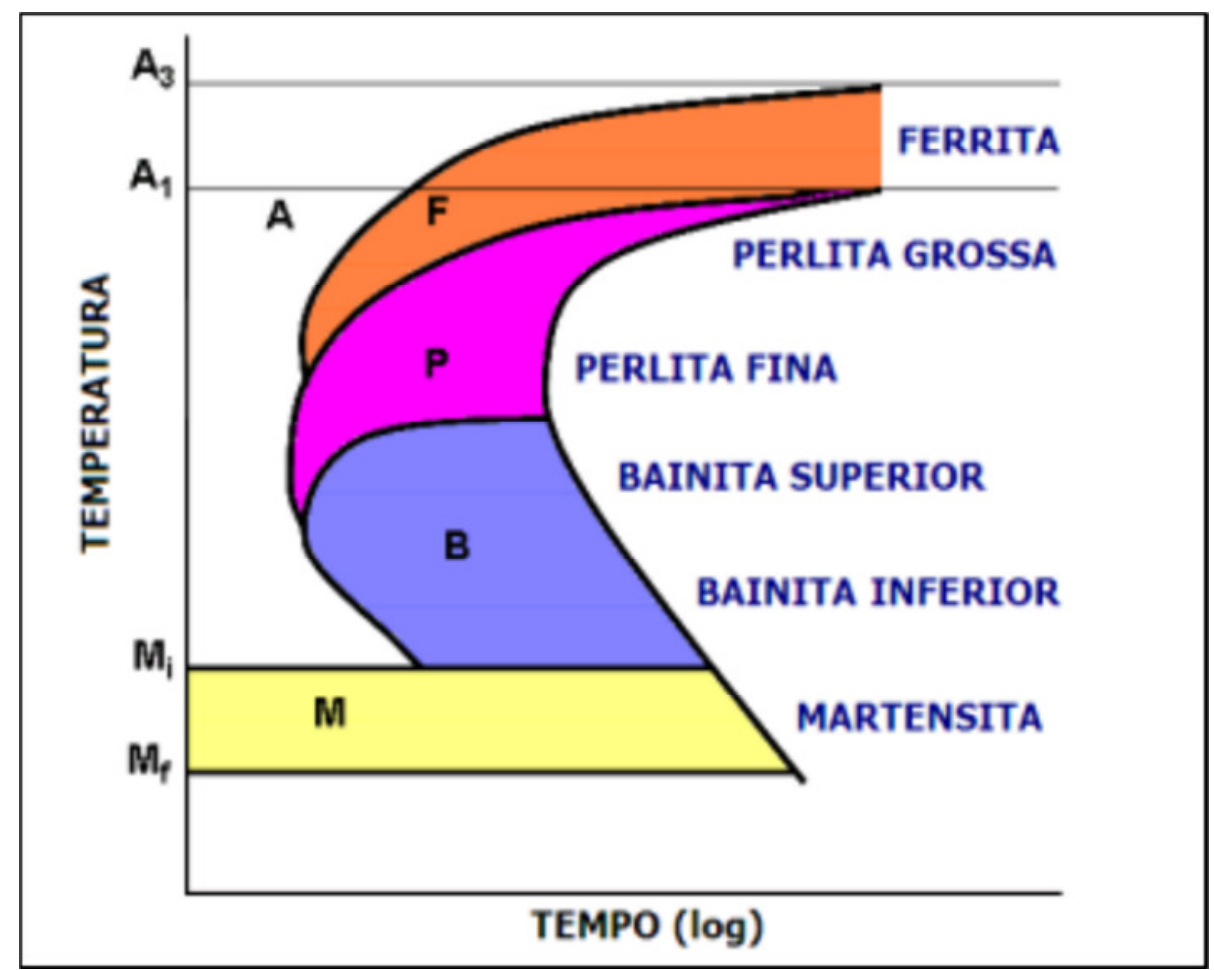

Figura 13. Diagrama esquemático CCT (termo em inglês para "Continous cooling transformation'), (CARMO, 1995).

Nas figuras 14 e 15 apresentam-se a bainita na forma de agulhas semelhantes às de martensita, resultante de tratamentos térmicos de austêmpera, ou seja, transformação isotérmica. 


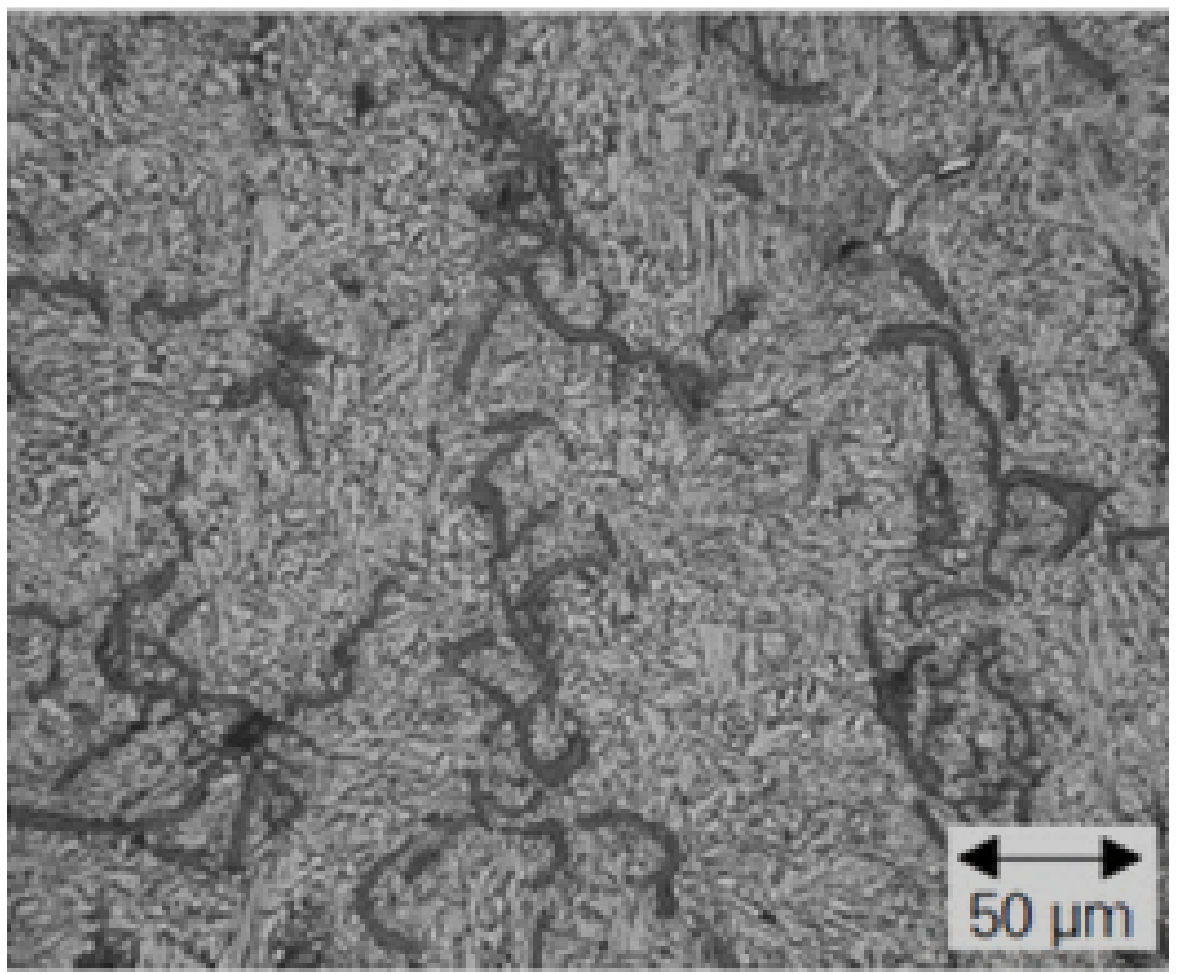

Figura 14 - Ferro Fundido Bainítico. Ataque da matriz com Nital 5 \%. Grafita tipo A e B com tamanhos de 5 a 8 distribuídas em uma matriz bainítica com perlita fina.

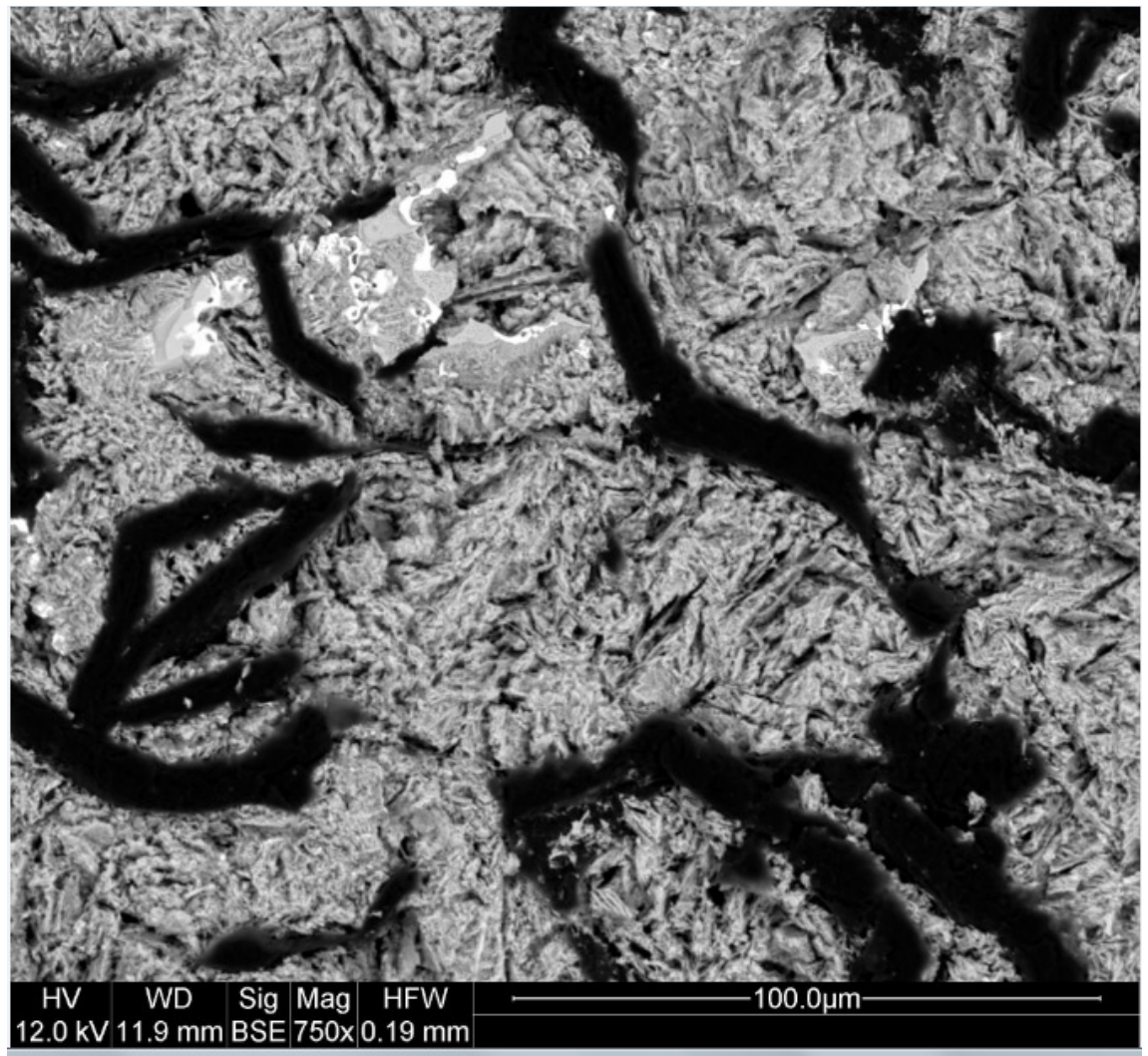

Figura 15 - Ferro Fundido Bainítico. Ataque da matriz com Nital $5 \%$. Grafita tipo A e B com tamanhos de 5 a 8 distribuídas em uma matriz bainítica com perlita fina. 


\subsection{Mecanismo de corrosão para o ferro fundido}

O processo de corrosão consiste na ocorrência simultânea de pelo menos uma reação anódica e uma reação catódica. A carga elétrica produzida na reação anódica é totalmente absorvida pela reação catódica. Se a solução é uma boa condutora, o metal que sofre corrosão assume um potencial de eletrodo, que é chamado potencial de corrosão (WOLYNEC, 2003).

Quando se trata de ferro de alta pureza, com superfície extremamente uniforme, a presença de uma quantidade suficiente de oxigênio, origina óxido de ferro hidratado que é a forma menos solúvel de óxido de ferro. Se no ponto de ataque, ocorrer forte aderência de ferrugem, por ausência de movimento, é possível que o ataque não seja finalizado. No entanto, normalmente há muitas áreas no material sob corrosão onde o comportamento é diferente. Essa diferença de comportamento pode ocorrer também no meio circunvizinho. Como este é em geral, condutor de eletricidade, cria-se uma diferença de potencial entre as várias regiões de comportamento diferente que resultam em células galvânicas, entre anodos locais e catodos na superfície do metal, provocando a continuidade da corrosão (RAMANATHAN, 1990).

O termo corrosão é geralmente usado para descrever a deterioração dos metais, não se aplicando a materiais não metálicos. No entanto, de acordo com a conceituação mais moderna, entende-se por corrosão a deterioração dos materiais em geral, pela ação do meio. Quando a corrosão ocorre, o metal perde suas qualidades essenciais, tais como resistência mecânica, elasticidade, ductilidade e o produto de corrosão formado geralmente é extremamente pobre, em termos destas propriedades.

Quando se trata do tipo de corrosão apresentado pelas ligas de ferro fundido, estas apresentam as mesmas formas gerais de corrosão como outros metais e ligas. Alguns exemplos das formas de corrosão observadas nos ferros fundidos incluem a corrosão galvânica, a corrosão seletiva ou grafitização, ataque uniforme ou generalizado, corrosão intergranular, corrosão - erosão, corrosão sob tensão e corrosão associada a fadiga.

A corrosão seletiva em ferros fundidos cinzentos ou grafitização é o tipo de corrosão mais comum nestes materiais. $\mathrm{Na}$ grafitização ocorre o ataque seletivo da matriz de um ferro fundido e a grafite permanece intacta. Este tipo de corrosão é também conhecido como corrosão grafítica. A corrosão grafítica é a 
corrosão que ocorre no ferro fundido cinzento e no ferro fundido nodular, à temperatura ambiente. Nesta, devido à heterogeneidade do material, o mecanismo eletroquímico da grafitização causa o ataque localizado e destrutivo da matriz de ferrita ( $\alpha-\mathrm{Fe})$, que funciona como anodo. A reação de oxidação que ocorre no anodo causa a dissolução do ferro de acordo com a reação 1.

$$
\mathrm{Fe} \rightarrow \mathrm{Fe}^{2+}+2 \mathrm{e}^{-}
$$

Nas áreas catódicas, regiões onde se encontram a grafita ocorrem a redução do oxigênio dissolvido com formação de íon hidroxila e, eventualmente, a liberação de hidrogênio gasoso, segundo as reações indicadas em (2) e (3):

$$
\begin{aligned}
& 2 \mathrm{H}^{+}+2 \mathrm{e}^{-} \rightarrow \mathrm{H}_{2} \\
& \mathrm{O}_{2}+2 \mathrm{H}_{2} \mathrm{O}+4 \mathrm{e}^{-} \rightarrow 4 \mathrm{OH}^{-}
\end{aligned}
$$

O ataque localizado causa no material um aspecto poroso e muito frágil, mecanismo este que é representado na Figura 16 (MAINIER et al. 2007).

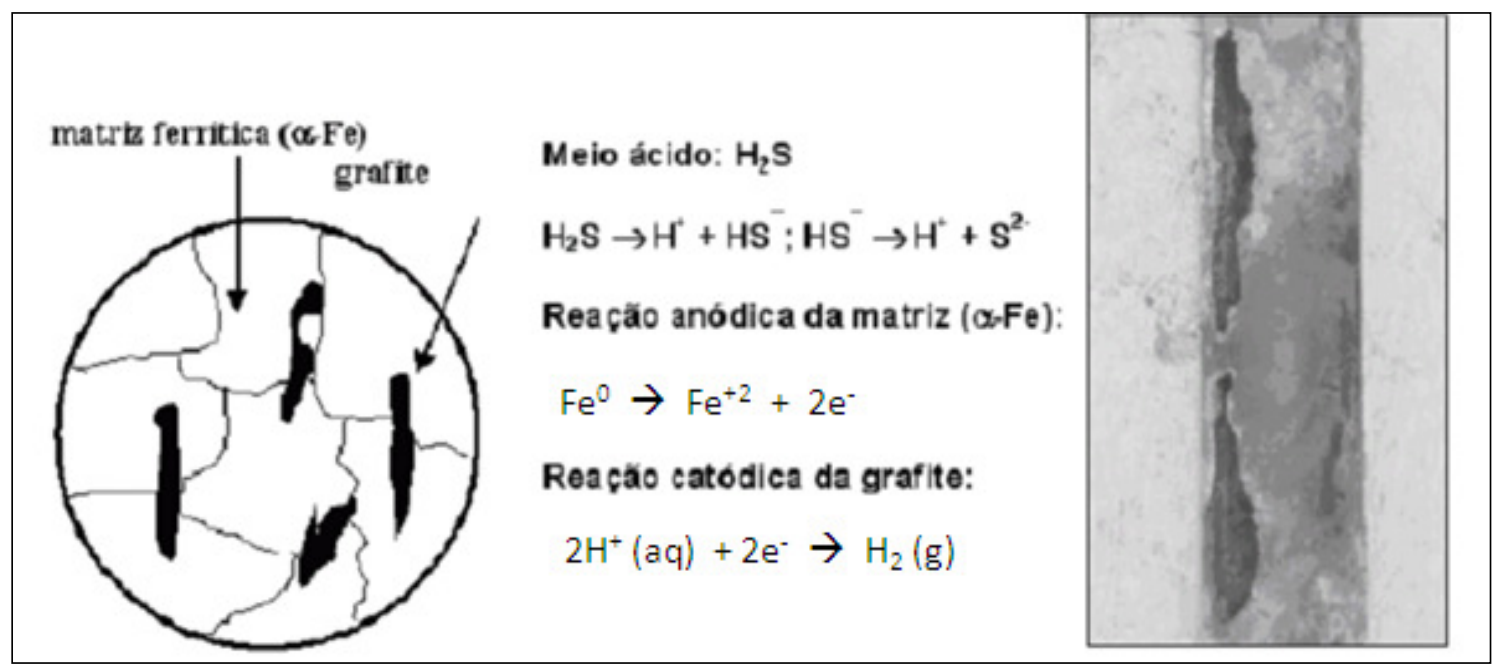

Figura 16 - Mecanismo de grafitização em ferro fundido na presença de $\mathrm{H}_{2} \mathrm{~S}$ (MAINIER et al., 2007).

Outro mecanismo de corrosão muito comum nas ligas de ferro fundido é a corrosão galvânica. Este tipo de corrosão ocorre quando um metal ou liga está conectado eletricamente em outro metal em um mesmo eletrólito. A intensidade deste tipo de corrosão será proporcional à diferença de potencial eletroquímico dos materiais envolvidos no processo. Neste tipo de corrosão, tem influência a 
proporção entre as áreas anódica e catódica. Tal proporção deverá ser a menor possível em vista de se obter a mínima corrosão na área anódica aliada a sua uniformidade.

\subsubsection{Corrosão do ferro fundido em diferentes meios}

As ligas de ferros fundidos oferecem uma alternativa econômica para equipamentos de construções e transporte de líquidos, onde se é necessário uma resistência à corrosão relativamente adequada aos meios utilizados (ASM HANDBOOK, 1996).

Durante muitos anos os ferros fundidos vêm sendo utilizados como um dos principais materiais na produção de tubulações para drenagem de resíduos e aplicações de encanamentos para ventilação e distribuição de água. Em consequência, diversos estudos foram realizados visando entender o mecanismo de corrosão destas ligas em diversos meios e com tempos controlados para os ensaios de imersão.

Algumas aplicações dos ferros fundidos incluem o transporte de água, de ácidos, soluções alcalinas, soluções salinas, compostos orgânicos, compostos de enxofre e metais líquidos. Este transporte é realizado com o auxilio de tubos que podem ficar expostos ao ambiente ou em contato com o solo. A resistência à corrosão no ambiente, como o solo, faz com que o ferro fundido cinzento seja vastamente utilizado para aplicações de encanamento (MEHRA e SONI, 2002).

Outras aplicações onde se utilizam ligas de ferro fundido são os tubos coletores de gases do sistema de escapamento. Os coletores são produzidos em ligas de ferro fundido por apresentarem vantagens fabricação em diferentes moldes. No entanto, avaliações realizadas por EKSTRÖM, (2013), relatam que a estes tubos em contado com gases condensados do sistema de exaustão de veículos estão promovendo a corrosão neste componente.

Segundo a literatura consultada, a perda de massa de amostras de ferros fundidos imersos em diferentes soluções salinas, apresentam um aumento progressivo em diferentes tempos de imersão e, principalmente, em meios onde exista a presença de íons cloreto e sulfato (MEHRA e SONI (2001), MOHEBBI e LI (2011), UKOBA et al. (2012).

MEHRA e SONI (2001) estudaram a deteriorização do ferro fundido em meio de diferentes soluções aquosas de sais presentes na água potável avaliando 
o comportamento relativo destes sais em relação à corrosão, por meio de ensaios de perda de massa, taxa de corrosão, curvas potenciodinâmicas, potencial de circuito aberto, densidade de corrente de corrosão e coeficiente de tafel. Foi relatado que o ferro fundido em soluções de sais de halogênios apresentou taxa de corrosão alta em comparação a sais de carbonatos. O aumento relativo da taxa de corrosão também foi observado em sais de sulfato e nitrato.

MOHEBBI e LI (2011) avaliaram em seu estudo a corrosão do ferro fundido utilizado em tubo de transporte de líquidos, com a verificação do comportamento de corrosão em tempos maiores do que horas, no caso, dias e semanas. Relatam que a microestrutura do ferro fundido é um fator chave que afeta o comportamento de corrosão nos tubos.

UKOBA et al. (2012). Estudou a taxa de corrosão do ferro dúctil em diferentes tempos de imersão ao longo de seis meses, em meio de solução de cloreto de sódio, simulando o ambiente marítimo, bem como em meio alcalino. Observou que houve um aumento na taxa de corrosão nos primeiros meses de imersão que foi diminuindo com o tempo. O meio em que os materiais tiveram uma maior taxa de corrosão foi o de cloreto de sódio.

Em aplicações onde é necessário o armazenamento ou transporte de ácido sulfúrico, diluído ou concentrado, o ferro fundido austenítico, ferro fundido com alto teor de níquel (Ni-resist) e os ferros fundidos com alto teor de silício, são os mais utilizados. No entanto, os ferros fundidos baixa liga também podem ser empregados, limitando-se apenas a aplicações com baixa velocidade de transporte, baixa temperatura da solução e baixas concentrações, menor que 70 \% de ácido sulfúrico.

Em soluções concentradas, o ferro puro de matriz ferrítica é mais utilizado do que os ferros fundidos cinzentos de matriz perlítica. Esta escolha se aplica devido ao mecanismo de grafitização, que pode ocorrer nos ferros fundidos cinzentos, sendo acelerado pela presença do ácido causando aquecimento. $O$ ferro puro também sofre corrosão, no entanto, em taxas mais baixas.

Os ferros fundidos com alto teor de silício são uma boa escolha para aplicações em meios com ácido sulfúrico, porém quando utilizados com ácido sulfúrico concentrado (100\%) e em meios onde contenha trióxido de enxofre $\left(\mathrm{SO}_{3}\right)$, pode ocorrer o ataque rápido da matriz. Estes materiais não apresentam facilidade na formação de filmes passivos; sendo assim, nas primeiras $24 \mathrm{~h}$ de 
serviço, a taxa de corrosão é relativamente alta, diminuindo após $48 \mathrm{~h}$ de trabalho (ASM HANDBOOK, 1996).

A corrosão em componentes motores presentes na câmara de combustão, ou no sistema de exaustão, está normalmente relacionada à formação de ácidos, como sulfúrico e nítrico, neste ambiente. Estes ácidos são gerados pela condensação dos gases de combustão que acontece geralmente nos sistemas de exaustão dos veículos.

O estudo do mecanismo de corrosão em presença de condensados sintéticos de exaustão de veículos foi relatado por alguns autores, DI CUNTO (2005), SANTOS (2006), PRATES (2009), MENEZES (2010). Aços inoxidáveis utilizados no sistema de escapamento de veículos e camisas de cilindros automotivos em liga de alumínio foram os principais materiais estudados.

DI CUNTO (2005) caracterizou em seu estudo a resistência à corrosão dos aços inoxidáveis ferríticos usados na parte fria do sistema de exaustão de veículos em meio de condensado sintético proveniente de motores à gasolina, utilizando ensaios eletroquímicos para avaliação da taxa de corrosão e ensaios de imersão.

SANTOS (2006) realizou uma caracterização das ligas de Al-Si hipereutéticas produzidas por conformação por "spray" e utilizadas na fabricação de camisas de cilindros automotivos, quanto a textura, dureza, microestrutura e resistência a corrosão. O meio utilizado foi um condensado sintético automotivo proveniente de motores à gasolina.

PRATES (2009) estudou o comportamento frente à corrosão de aços inoxidáveis ferríticos utilizados na fabricação de parte do sistema de exaustão de veículos em meio a uma solução sintética de condensado de álcool combustível. Esta solução foi formulada com base em análises químicas de amostras da solução natural coletadas diretamente do veículo movido a álcool.

MENEZES (2010), bem como PRATES (2009), estudou a corrosão em diferentes aços inoxidáveis, como materiais alternativos para fabricação do sistema de escapamento de veículos automotivos, em meio de condensado sintético de condensado de álcool etílico com teor de cloreto de $24 \mathrm{mg} / \mathrm{l}$, com o intuito de acelerar o processo corrosivo nas amostras.

Nesta dissertação, foi realizado o estudo da corrosão em ligas de ferro fundido usadas em camisas de cilindros automotivos em meio de um condensado 
automotivo natural, coletado com o auxílio de um equipamento que realiza medições de emissões em motores que circulam com diesel como combustível. De forma comparativa, um condensado sintético também foi utilizado, baseado em uma norma automotiva de origem Alemã, VDA 230-214.

A associação alemã da indústria automobilística (VDA), termo em alemão para "Verband der Automobilindustrie", estabeleceu muito recentemente um novo procedimento padrão para ensaios de corrosão de materiais metálicos expostos aos condensados de escape utilizando uma solução sintética, especificada a partir da composição dos gases de exaustão de veículos movidos a diesel, (HARTMANN, 2012).

A VDA promove o interesse das indústrias automotivas em âmbito nacional e internacional. Ela consiste de aproximadamente 600 membros, como fabricantes de automóveis, fornecedores, fabricantes de componentes automotivos, entre outros. Os interesses dos membros da VDA são na política econômica de transportes, legislação técnica e garantia da qualidade. Além disto, a proteção do meio ambiente é sua prioridade. O resultado do ensaio proposto na Norma VDA 230-214 deve dar informações sobre a tendência à corrosão dos materiais quando expostos aos gases de exaustão condensados. A composição do condensado sintético que deve ser utilizado no ensaio proposto nesta Norma, depende do tipo de aplicação.

Os condensados sintéticos propostos na Norma VDA 230-214 para aplicações em meios considerados agressivos estão inseridos nos grupos K1.1 e K1.2 e são provenientes de combustíveis com alto teor de enxofre. Os condensados para aplicações consideradas moderadas, estão no grupo K2.1 e correspondem a combustíveis com baixo teor de enxofre. A composição química de ambos os grupos é apresentada na tabela 3.

A composição destes condensados sintéticos, conforme descrito na tabela 3, contendo ácidos minerais, como ácido sulfúrico e acido nítrico, e ácidos orgânicos, como ácido fórmico e ácido acético. $\mathrm{O}$ valor de $\mathrm{pH}$ destes condensados é encontrado entre 1 e 4. Para a simulação das condições práticas, o ensaio proposto na Norma VDA 230-214 é intermitentes utilizando um dos condensados e normalmente combinando ciclos alternados de imersão no condensado com períodos de secagem em temperaturas elevadas e controladas e ciclos de condensação. No entanto, este ensaio não foi explorado neste trabalho pelo fato 
de se necessitar equipamento que promove a condensação da solução para realização do mesmo.

HARTMANN (2012) baseou-se na Norma VDA 230-214 para a realização dos seus estudos, em que utilizou ligas de aços inoxidáveis soldadas e de uso em partes do sistema de escape dos veículos. Estes materiais são amplamente utilizados na fabricação de sistema de escape na União Européia, Estados Unidos e Japão. Estes países realizaram alterações nos materiais do sistema de exaustão em partes da América do Sul e Ásia, locais para onde alguns veículos são exportados e/ou produzidos. Devido à baixa qualidade de combustíveis nestes países, particularmente teor de enxofre elevado, o estudo da corrosão nestes materiais foi essencial.

TABELA 3. Composição do condensado sintético da norma VDA adotado neste estudo

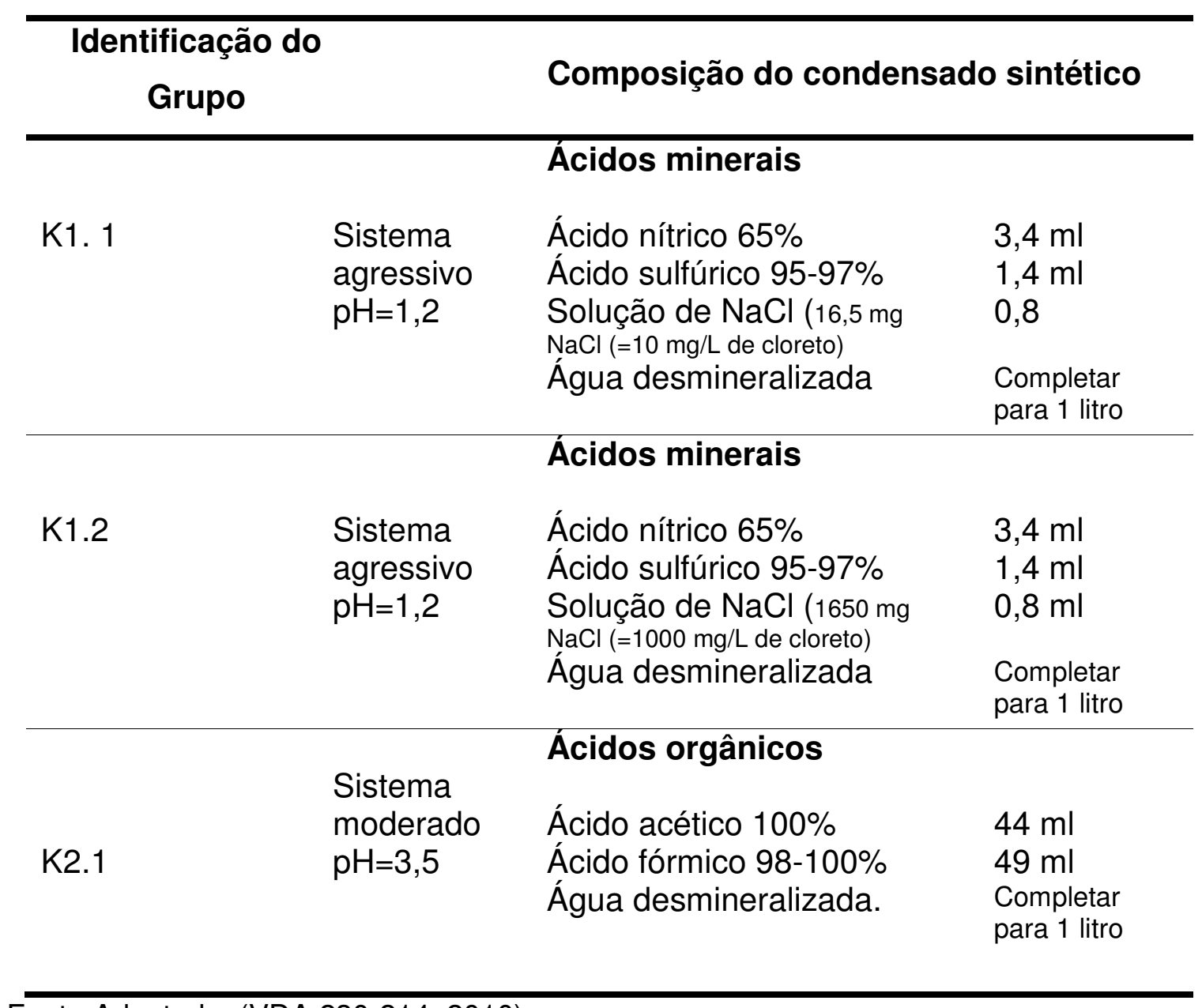

Fonte Adaptada: (VDA 230-214, 2010). 


\subsubsection{Comportamento de corrosão do ferro fundido e características dos produtos de corrosão.}

Os autores MISAWA et al. (1971) e SARIN et al. (2000), realizaram suas invertigações expondo as amostras em meios neutros, como a água e meios com alta salinidade, como cloreto de sódio simulando o ambiente marinho.

A estrutura cristalográfica das camadas de produtos de corrosão formadas sobre o ferro fundido, aço carbono e o ferro puro, expostos às mesmas condições são similares. Sobre ambos os metais os principais compostos presentes são: $\alpha-\mathrm{FeOOH}$ (goethita), $\beta-\mathrm{FeOOH}$ (akaganeita), $\quad \gamma$ - $\mathrm{FeOOH}$ (lepidocrocita), $\delta$ - $\mathrm{FeOOH}$ (amorfo) e $\mathrm{Fe}_{3} \mathrm{O}_{4}$. A diferença que existe entre as duas camadas é a compactação e o nível de porosidade resultante do arranjo dos compostos presentes. SARIN et al. (2000) investigaram a influência dos produtos de corrosão de um ferro fundido e de um ferro puro na contaminação da água potável. Realizaram avaliações para identificação dos principais produtos de corrosão em ambos os materiais após a secagem do produto. Observaram que os produtos apresentavam $\alpha-\mathrm{FeOOH}$ (goethita), $\mathrm{FeO} . \mathrm{Fe}_{2} \mathrm{O}_{3}$, magnetita e $\gamma-\mathrm{FeOOH}$ (lepidocrocita).

Segundo MISAWA et al. (1971), no caso do aço carbono e do ferro fundido a ferrugem é constituída por uma camada desordenada da $\delta-\mathrm{FeOOH}$ amorfo com ilhas espaças de $\alpha-\mathrm{FeOOH}, \beta-\mathrm{FeOOH}$ e/ou $y-\mathrm{FeOOH}$ e $\mathrm{Fe}_{3} \mathrm{O}_{4}$.

$A$ formação da ferrugem, que é o óxido de (III) mono-hidratado $\left(\mathrm{Fe}_{2} \mathrm{O}_{3} \cdot \mathrm{H}_{2} \mathrm{O}\right)$, um composto que possui coloração castanho-avermelhada. $A$ ferrugem se forma quando o ferro se oxida na presença de ar e água. Ocorrendo a oxidação do ferro metálico a cátion ferro, conforme ilustrado na reação 4.

$$
\mathrm{Fe}_{(\mathrm{s})} \rightarrow \mathrm{Fe}^{2+}+2 \mathrm{e}^{-}
$$

Simultaneamente, há a seguinte reação para redução da água, ilustrado na reação 5 .

$$
2 \mathrm{H}_{2} \mathrm{O}+2 \mathrm{e}^{-} \rightarrow \mathrm{H}_{2}+2 \mathrm{OH}^{-}
$$

Ocorrendo a formação do hidróxido ferroso $\left(\mathrm{Fe}(\mathrm{OH})_{2}\right)$, que na presença de oxigênio é oxidado a hidróxido de ferro (III) $\left(\mathrm{Fe}(\mathrm{OH})_{3}\right)$. Posteriormente, ele 
perde água e se transforma no óxido de ferro (III) mono-hidratado $\left(\mathrm{Fe}_{2} \mathrm{O}_{3} \cdot \mathrm{H}_{2} \mathrm{O}\right)$, denominado ferrugem.

O diagrama de Pourbaix (1976) para sistema ferro-água, apresentamse as condições de estabilidade temodinâmica do ferro e dos seus derivados que podem existir na presença de água ou soluções aquosas. A corrosão eletroquímica será mais intensa, quanto maior for à acidez, ou seja, um teor elevado de $\mathrm{H}^{+}$, e o teor de oxigênio no eletrólito (GENTIL, 2003). Na figura 17 é mostrado o diagrama de Pourbaix para o sistema Ferro-Água.

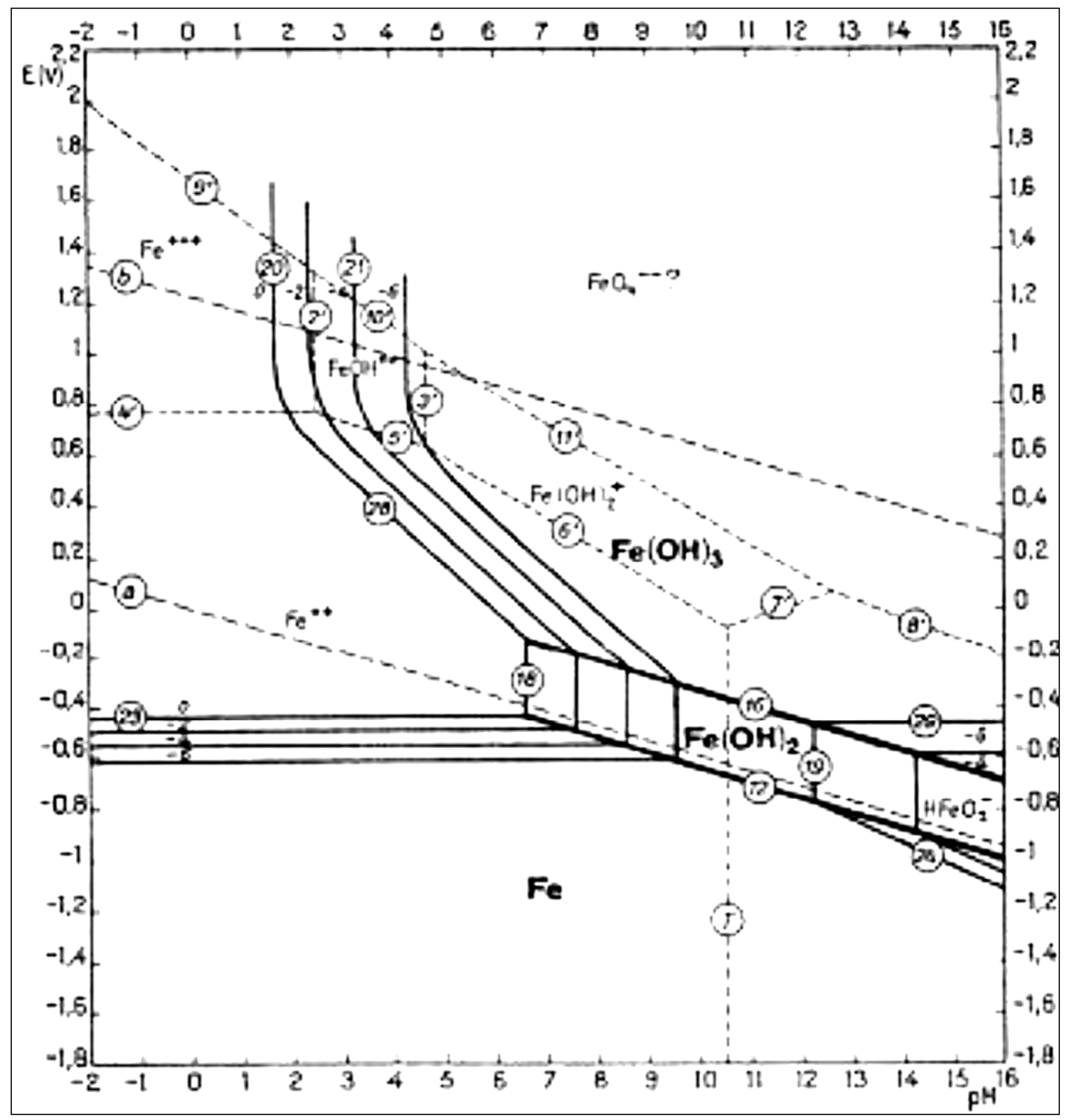

Figura 17 - Diagrama de Equilibrio versus $\mathrm{pH}$, para o sistema Ferro-Água, a $25^{\circ} \mathrm{C}$. (POURBAIX, 1976) 
Na figura 18 apresenta-se um esquema de equilíbrio termodinâmico dos diferentes estados em que o ferro pode encontrar-se em meio aquoso. O diagrama de Pourbaix mostra que em baixos potenciais o ferro apresenta imunidade, não reagindo com o meio. Ainda assim, diversas reações podem estar ocorrendo na superfície. Nesta região não existe a possibilidade de ocorrer a degradação do material. Em outra situação, com potenciais mais altos e na faixa de pH ácido, o ferro pode se apresentar ativo e com dissolução constante. Neste caso, o ferro forma uma película de óxido que poderá protegê-lo, tornando-o passivo, a depender também do $\mathrm{pH}$. Como se observa no diagrama o estado de passivação também ocorre em pH alcalino.

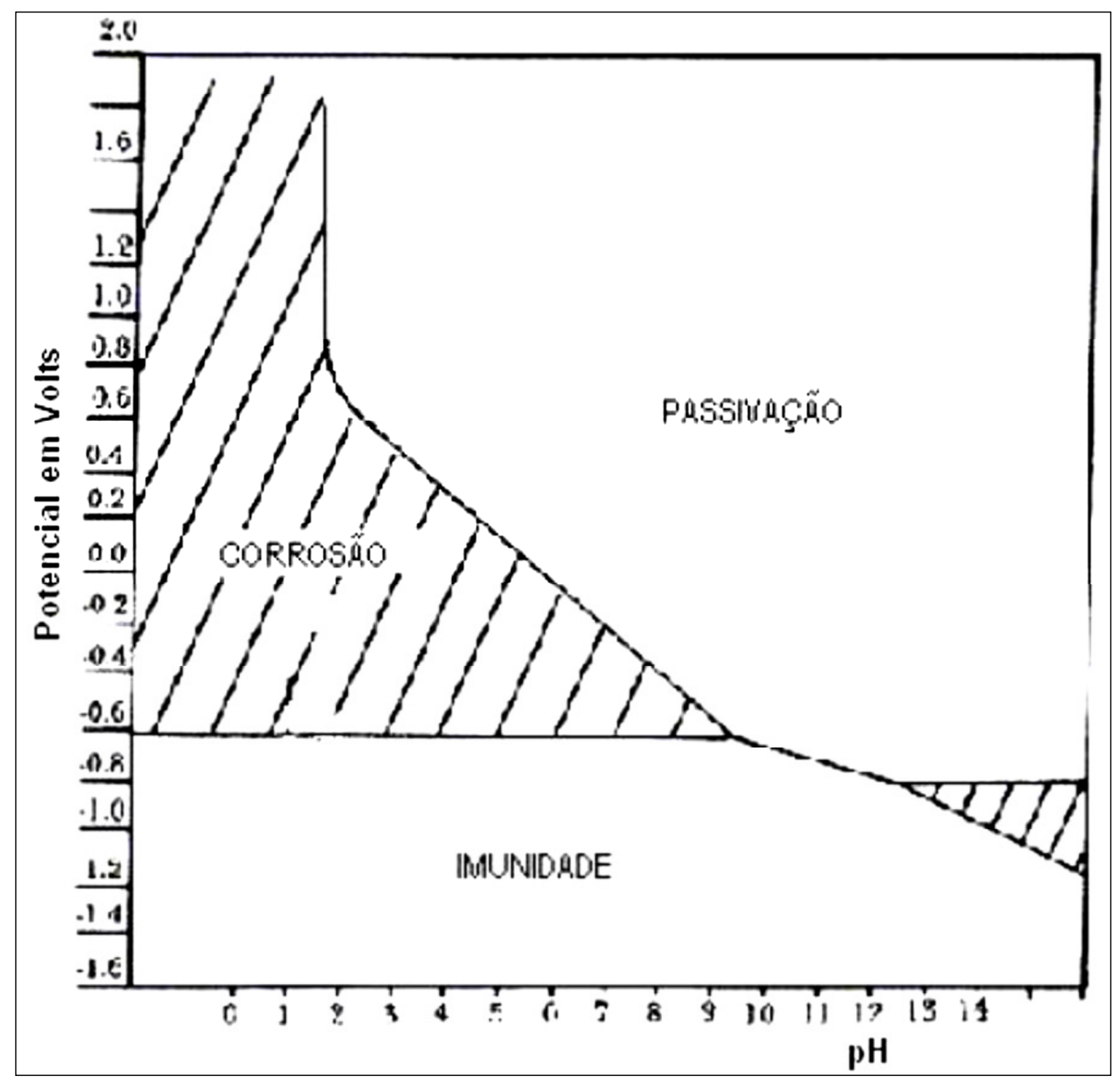

Figura 18 - Diagrama de Equilibrio dinamico de Pourbaix. Sistema Ferro-Água, com os limites de corrosão, passivação e imunidade. (POURBAIX, 1976). 


\subsubsection{Efeito da microestrutura na corrosão do ferro fundido}

Um fator importante no estudo da corrosão das ligas de ferro fundido é o da microestrutura destes materiais, o que permite compreender o mecanismo de corrosão dos mesmos. O processo corrosivo nestes materiais se inicia nas regiões próximas à grafita, e esta, por não sofrer ataque corrosivo permanece intacta na microestrutura. Comparando-se o aço carbono convencional com um ferro fundido cinzento, o primeiro apresenta o ataque mais acentuado e homogêneo devido à ausência de grafite livre, promovendo um produto de corrosão de baixa aderência à superficie do material. O produto de corrosão, sendo removido facilmente, permite a exposição da superficie ao meio corrosivo, favorecendo o ataque da mesma. Este mecanismo dificilmente ocorre com o ferro fundido cinzento, devido ao tipo de estrutura formada na camada de produtos de corrosão, fator determinante na cinética do processo corrosivo.

Alguns estudos relatam sobre e influência da microestrutura do ferro fundido no comportamento de corrosão destes materiais.

MIYATA et. al. (2013) apresentam em seu estudo a avaliação da taxa de corrosão para um ferro fundido nodular com diferentes áreas com microestrutura perlítica em sua matriz em comparação ao ferro puro. O meio utilizado foi uma solução de ácido sulfúrico a temperatura ambiente. As avaliações da inclinação anódica das curvas de Tafel indicou que a taxa de corrosão não é influenciada pela quantidade de perlita na matriz. A dissolução anódica do ferro fundido nodular apresentou densidade de corrrente anodica mais elevada do que o ferro puro.

PRASANNA et. al (2009) SIDDARAJU et al. (2013) relatam em seus estudos sobre influência da microestrutura na resistência à corrosão de ligas de ferro fundido dúctil. Estes materiais quando submetidos a tratamentos térmicos apresentam a formação da microestrutura bainítica. Os ensaios de corrosão realizados nestes materiais mostraram que o material com microestrutura bainítica apresenta uma resistência à corrosão elevada em comparação com o ferro fundido dúctil sem tratamento térmico.

AJELL e HASONI (2008) relatam em seu estudo que o teor e a forma da grafita presente nas ligas de ferro fundido afeta diretamente a resistência à corrosão destes materiais. O teor de grafite livre induz a formação de um produto de corrosão em conjunto com o ferro e outros elementos de liga. A aderência 
deste produto sob a superfície metálica promove o aumento da resistência à corrosão. A camada formada atua como uma barreira, impedindo o avanço do ataque.

MOHEBBI (2011) apresentou em seu estudo o mecanismo de corrosão em um ferro fundido de microestrutura perlítica, com a presença da fase ferrítica e da fase eutética fosforosa (steadita). A fase ferrítica é a primeira a sofrer a corrosão, principalmente por estar sempre localizada próxima à grafita. Este fato permite a formação de um par galvânico. Embora a fase ferrítica apresente facilidade em formar filmes passivos, o fato de estar próximo a um material mais nobre, terá sua resistência diminuída. As demais fases sofrem corrosão conforme a ordem de reatividade, a fase eutética fosforosa sendo a última a sofrer corrosão.

Tratando-se do produto de corrosão formado pelo do ataque da matriz das ligas de ferro fundido, FÓFANO (2000) e EKSTRÖM (2013) relatam que a formação de filmes porosos induz normalmente a continuidade ou aumento dos danos por mecanismos de corrosão localizados, formação de pites e alvéolos. Entretanto, a formação de filmes contínuos e aderentes, reduz a velocidade do processo de difusão e, consequentemente, a dissolução do metal.

MEHRA e SONI (2001) descrevem a formação de filmes passivos em algumas ligas de ferro fundido e que são penetrados por sais de halogênios, especificamente cloretos, que permitem o início do ataque corrosivo. Os ânions que apresentam uma influência significativa na corrosão de ferros fundidos são os íons cloreto e sulfato. 


\section{MATERIAIS E MÉTODOS}

No presente trabalho foram estudados os materiais de dois tipos de camisas em ferro fundido cinzento, uma com microestrutura perlítica e outra com microestrutura bainítica.

As amostras utilizadas para realização dos ensaios propostos neste estudo foram extraídas de camisas de cilindros automotivos, que estavam em estoque na Mahle Metal Leve S/A (MML), preparadas para fornecimento aos clientes.

As camisas estavam em conformidade com as especificações das Normas MML, D2623 para material perlítico e F4027 para material bainítico.

As amostras estudadas foram analisadas quanto a composição química no estado sólido utilizando-se um Espectrômetro de Emissão Ótica, Modelo SPECTROLAB. Os elementos carbono e enxofre foram analisados utilizando um Analisador C/S, marca LECO, Modelo CS200. A composição química nominal das ligas escolhidas para estudo neste trabalho é mostrada na tabela 4.

Tabela 4. Composição química nominal (\% em massa) dos elementos nos ferros fundidos cinzento estudados neste trabalho.

\begin{tabular}{ccc} 
Elemento & Ferro Fundido Perlítico & Ferro Fundido Bainítico \\
\hline Carbono & $3,20-3,50$ & $2,60-3,20$ \\
Enxofre & 0,06 máx. & 0,08 máx. \\
Silicio & $1,60-2,10$ & $1,40-2,20$ \\
Manganês & $0,60-0,80$ & 0,80 máx. \\
Fosforo & $0,35-0,50$ & 0,08 máx. \\
Cromo & $0,20-0,40$ & 0,50 máx. \\
Niquel & -- & $0,80-1,50$ \\
Molibdênio & $0,30-0,50$ & $0,80-1,50$ \\
Cobre & -- & --
\end{tabular}

Fonte: Adaptado (MAHLE D2623 E F4027). 
As microestruturas dos materiais estudados são mostradas nas figuras 19 e 20 para o material perlítico e o bainítico, respectivamente, com e sem ataque químico com Nital $3 \%$.

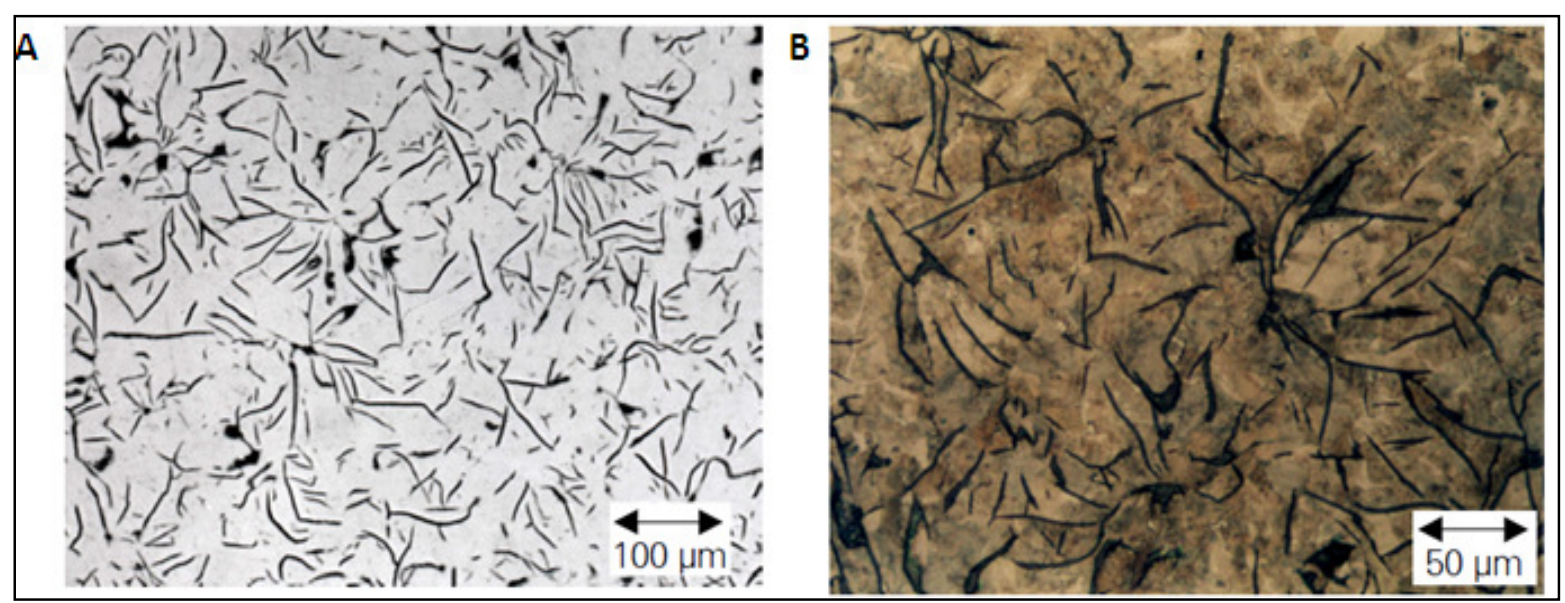

Figura 19 - Microestrutura do ferro fundido perlítico. Grafita: Forma I; distribuição B; tamanho 4 - 5 - (A) sem ataque e (B) após ataque com Nital $3 \%$.

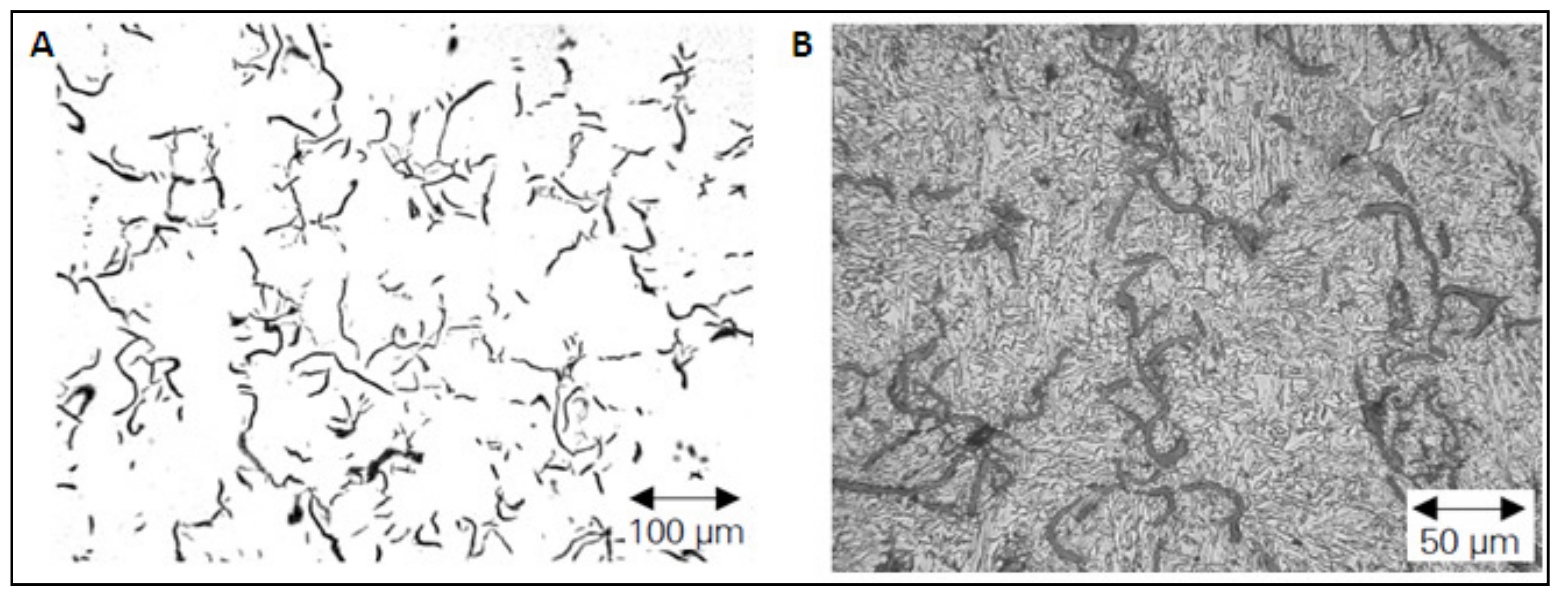

Figura 20 - Microestrutura do ferro fundido bainítico $(A)$ sem ataque e $(B)$ após ataque com Nital $3 \%$.

A figura 21 mostra um fluxograma das etapas envolvidas na metodologia adotada neste trabalho, desde a preparação dos materiais e meios para ensaios até os ensaios realizados. 


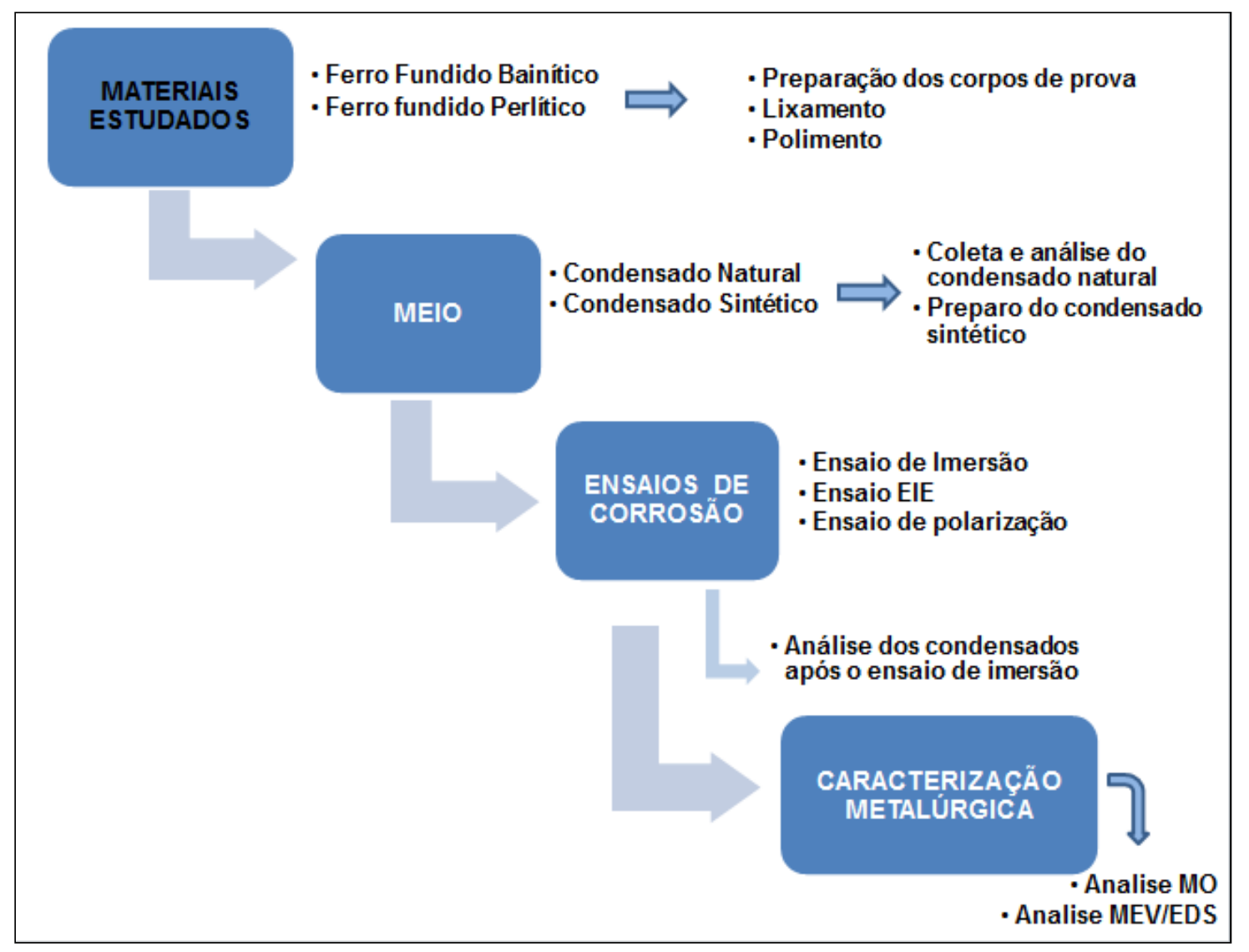

Figura 21 - Fluxograma das etapas da metodologia adotada neste estudo, desde a preparação dos materiais e meios, até os ensaios realizados.

\subsection{Meios utilizados nos ensaios de corrosão}

O estudo de corrosão foi realizado por ensaios de imersão e eletroquímicos em tempos determinados, com a finalidade de avaliar 0 desempenho dos materiais que hoje são utilizados na confecção de camisas de cilindros. Os meios utilizados foram um condensado automotivo natural e um condensado sintético automotivo.

O condensado natural foi coletado com o auxílio de um equipamento que realiza medições de emissões em motores que circulam com diesel como combustível. No equipamento o gás emitido pelo motor e que sai no escapamento do veículo é coletado no equipamento mede emissões, uma parte deste gás é analisado no próprio equipamento e o restante é condensado para ser descartado. Este condensado foi coletado para realização deste trabalho.

O condensado sintético utilizado foi baseado na Norma automotiva de origem Alemã, VDA 230-214. A proposta da norma VDA 230-214 é descrever um procedimento de ensaio de corrosão de materiais metálicos e superfícies utilizando uma solução sintética especificada a partir da composição dos gases de 
exaustão de veículos. Neste trabalho foi escolhido um dos condesados propostos na Norma, não foi utilizado o teste devido a ausência do equipamento de condensação que a Norma propõe.

As soluções utilizadas para a realização dos ensaios estão descritas a seguir.

a) Condensado Sintético: Recentemente, a associação alemã da indústria automotiva (VDA) termo em alemão para Verband der Automobilindustrie, estabeleceu um novo padrão de procedimento para ensaios de corrosão em materiais metálicos expostos a condensados, com uma definição da composição dos mesmos.

A composição dos condensados sintéticos provenientes de meios considerados agressivos está inserida nos grupos K1.1 e K1.2. Estes condensados são provenientes de ensaios que utilizam combustíveis com alto teor de enxofre, acima de 500 ppm. No presente trabalho, foi utilizada apenas a composição da solução do grupo $\mathrm{K} 1.1$, sistema agressivo de $\mathrm{pH} 1,2$, que simula meios com alto teor de enxofre, cuja composição é mostrada na tabela 5.

Tabela 5. Composição do condensado sintético da norma VDA adotado neste estudo.

\begin{tabular}{|c|c|c|c|}
\hline $\begin{array}{c}\text { Identificação do } \\
\text { Grupo }\end{array}$ & \multicolumn{3}{|c|}{ Composição do condensado sintético } \\
\hline & & Ácidos minerais & \\
\hline $\mathrm{K} 1.1$ & $\begin{array}{l}\text { Sistema } \\
\text { agressivo } \\
\mathrm{pH}=1,2\end{array}$ & $\begin{array}{l}\text { Ácido nítrico } 65 \% \\
\text { Ácido sulfúrico } 95-97 \% \\
\text { Solução de } \mathrm{NaCl}(16,5 \mathrm{mg} \mathrm{NaCl} \\
(=10 \mathrm{mg} / \mathrm{L} \text { de cloreto) } \\
\text { Água desmineralizada }\end{array}$ & $\begin{array}{l}3,4 \mathrm{ml} \\
1,4 \mathrm{ml} \\
0,8 \\
\text { Completar } \\
\text { para } 1 \text { litro }\end{array}$ \\
\hline
\end{tabular}

Fonte Adaptada: (VDA 230-214, 2010).

b) Condensado Natural: O condensado natural utilizado como meio corrosivo nos ensaios foi coletado por meio da utilização de um equipamento que realiza medições de emissões de gases poluentes de motores e que esta disponível na Mahle Metal Leve (MML). Na figura 22 é apresentado o equipamento usado para coleta do condensado natural instalado na MML, em um banco de teste de motores. Estes equipamentos são desenvolvidos especialmente para medições e controle de emissões durante a validação de motores de combustão interna. 
Para a coleta e análise dos gases, um duto foi conectado ao tubo de saída do sistema de exaustão do motor e acoplado ao equipamento de medição de emissões de motores. Dessa forma, foi possível determinar com precisão os teores de $\mathrm{CO}, \mathrm{CO}_{2}, \mathrm{CH}_{4}, \mathrm{NO}, \mathrm{NO}_{x}, \mathrm{O}_{2}$ e a taxa de EGR na forma gasosa durante o ensaio de medição de emissões. O excesso de gás não analisado foi desviado para uma serpentina onde o mesmo foi condensado. O líquido proveniente da condensação dos gases foi coletado em recipientes apropriados instalados na máquina. Este condensado natural, proveniente das reações de combustão do combustível, foi analisado, quanto à concentração dos diversos elementos presentes. Além disso, foram medidos o $\mathrm{pH}$ e a condutividade do meio.

Para caracterização do condensado natural foi utilizado um cromatógrafo líquido iônico (IC), LC20 Dionex. Para as medições de pH e de condutividade foi utilizado um equipamento Digimed modelo DM 31 com célula para medição do $\mathrm{pH}$ modelo $12 \mathrm{~K} 11131 \mathrm{e}$, para a de condutividade, um equipamento DMC 101M.

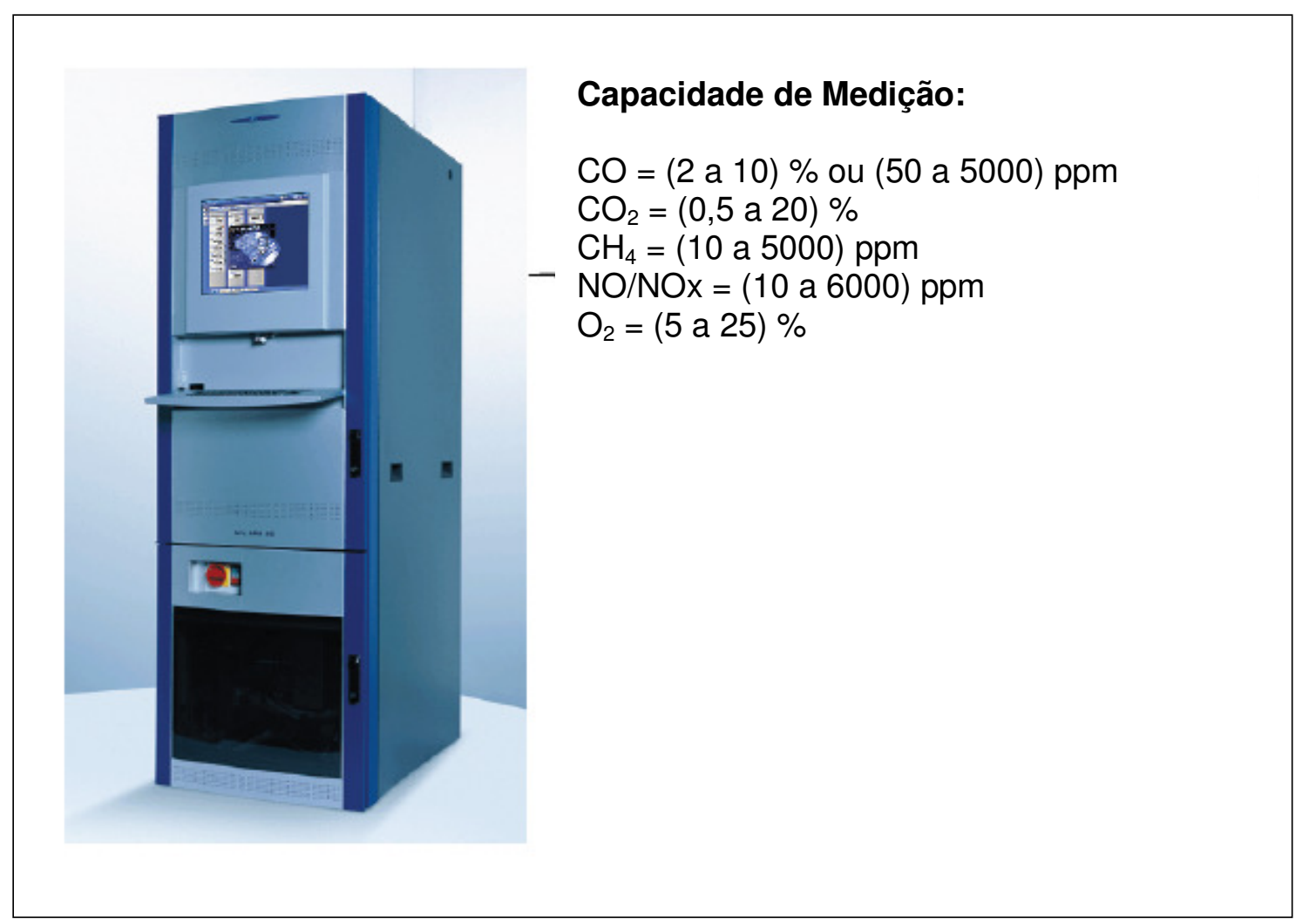

Figura 22 - Bancada de medição e controle de emissões da empresa Mahle Metal Leve.

Segundo PRATTES (2009), o recolhimento do condensado natural também pode ser realizado utilizando veículos, carros ou caminhões, conectando 
dutos ao sistema de exaustão, especificamente no tudo de saída do veículo. O gás coletado circula por alguns condensadores de vidro e o líquido proveniente da condensação dos gases são coletados em balões volumétricos e armazenados para realização das análises de caracterização.

\subsection{Confecção e preparo superficial dos corpos-de-prova (CP)}

Os corpos-de-prova (CP) dos materiais estudados neste trabalho, ferro fundido cinzento perlítico e bainítico, foram retirados, segundo o tipo, de um mesmo cilindro. $O$ objetivo era eliminar possíveis diferenças relativas às condições de fabricação, microestrutura e composição química.

Cada corpo-de-prova retirado destes cilindros foi preparado com as dimensões de $3,0 \mathrm{~cm}$ de comprimento $(\mathrm{x}), 2,0 \mathrm{~cm}$ de largura $(\mathrm{y})$ e espessura de $0,5 \mathrm{~cm}(\mathrm{z})$, como ilustrado na figura 23.

Os corpos-de-prova foram limpos com acetona, durante $10 \mathrm{~min}$. em ultrassom, para remoção de sujidades, tais como óleos provenientes da usinagem. Também foi realizado um tratamento superficial para remoção de óxidos e outras impurezas utilizando-se uma lixadeira Phoenix Beta (BUEHLER) e lixas para utilização com água com granulometrias de 120, 320, 400 e 600 Mesh. As amostras foram em seguida polidas utilizando-se uma politriz Phoenix Beta (BUEHLER) automática. O polimento foi realizado utilizando diferentes granulometrias até acabamento de $1 \mu \mathrm{m}$. O tempo e a pressão de polimento foram mantidos constantes em 3 min. e 3 psi de pressão. Para remoção de resíduos da pasta de polimento as amostras foram limpas com detergente, água destilada e desengraxadas em ultrassom com acetona por $10 \mathrm{~min}$.

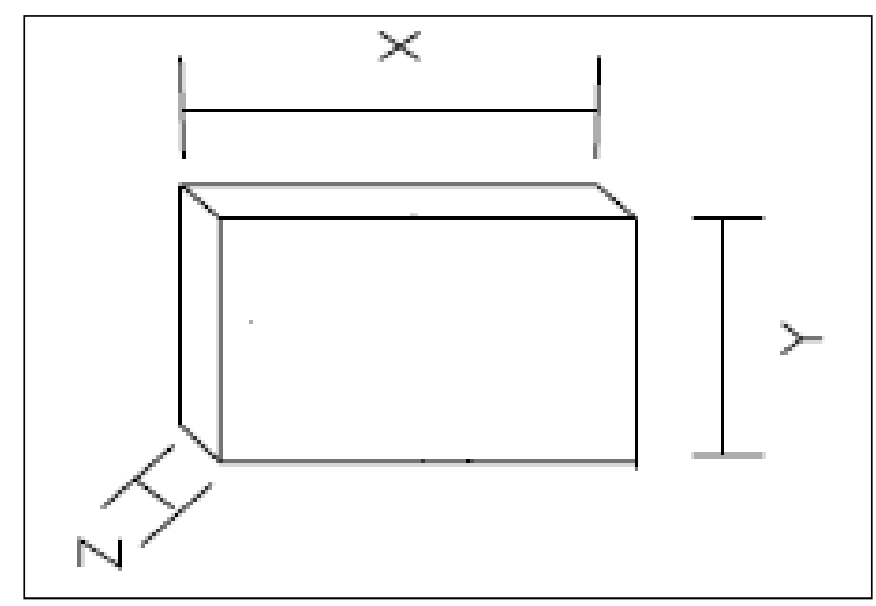

Figura 23 - Esquema do corpo-de-prova para os ensaios de corrosão. 


\subsection{Ensaio de imersão em presença de condensado natural e sintético.}

Para realização dos ensaios de imersão foram utilizados os condensados natural e sintético. O objetivo foi determinar o mecanismo de corrosão e o desempenho dos ferros fundidos perlítico e bainítico em ambas as soluções.

A temperatura de condução do ensaio foi de $25^{\circ} \mathrm{C}$. As amostras foram acondicionadas em diferentes béqueres com volumes fixos de $150 \mathrm{ml}$. Os tempos de imersão utilizados nos ensaios foram de $(2,6,8,16,48,96$ e 120) h. Os corpos-de-prova eram retirados dos béqueres nos tempos estabelecidos, em seguida lavados com água deionizada para remoção dos produtos de corrosão soltos na superfície e, finalmente, secados com ar quente. Os corpos-de-prova foram acondicionados em um dessecador para posterior caracterização metalúrgica. O condensado pós-teste de imersão foi acondicionado em frascos de plástico e lacrados para evitar evaporação da solução, para posteriormente serem analisados.

A análise química dos metais dissolvidos, presentes nos condensados sintético e natural, foi realizada utilizando-se um Espectrômetro de Emissão de Plasma (ICP), modelo Optima 200DV.

O comportamento eletroquímico foi avaliado por meio de ensaios de espectroscopia de impedância eletroquímica (EIE), em diferentes tempos de imersão a partir de $2 \mathrm{~h}$. Foram feitas 10 leituras por década de frequência com perturbação aplicada de $5 \mathrm{mV}$ em torno do potencial de corrosão. Para realização dos ensaios foi utilizado um Potenciostato / Galvanostato Modelo 273A da EG\&G Instruments - Princeton Applied Research conectado a um computador e controlado pelo programa "Corrosion Measurement \& Analysis Software" (352/252) em conjunto com um impedancimetro Solortron, apresentado na figura 24. Este potenciostado foi conectado a uma célula eletroquímica com eletrodo de calomelano saturado como eletrodo de referência de $\mathrm{Ag} / \mathrm{AgCl}$ e um contra eletrodo de platina, sistema apresentado na figura 25. A área da amostra exposta ao eletrólito foi de $1 \mathrm{~cm}^{2}$, volume do eletrólito $150 \mathrm{ml}$. 


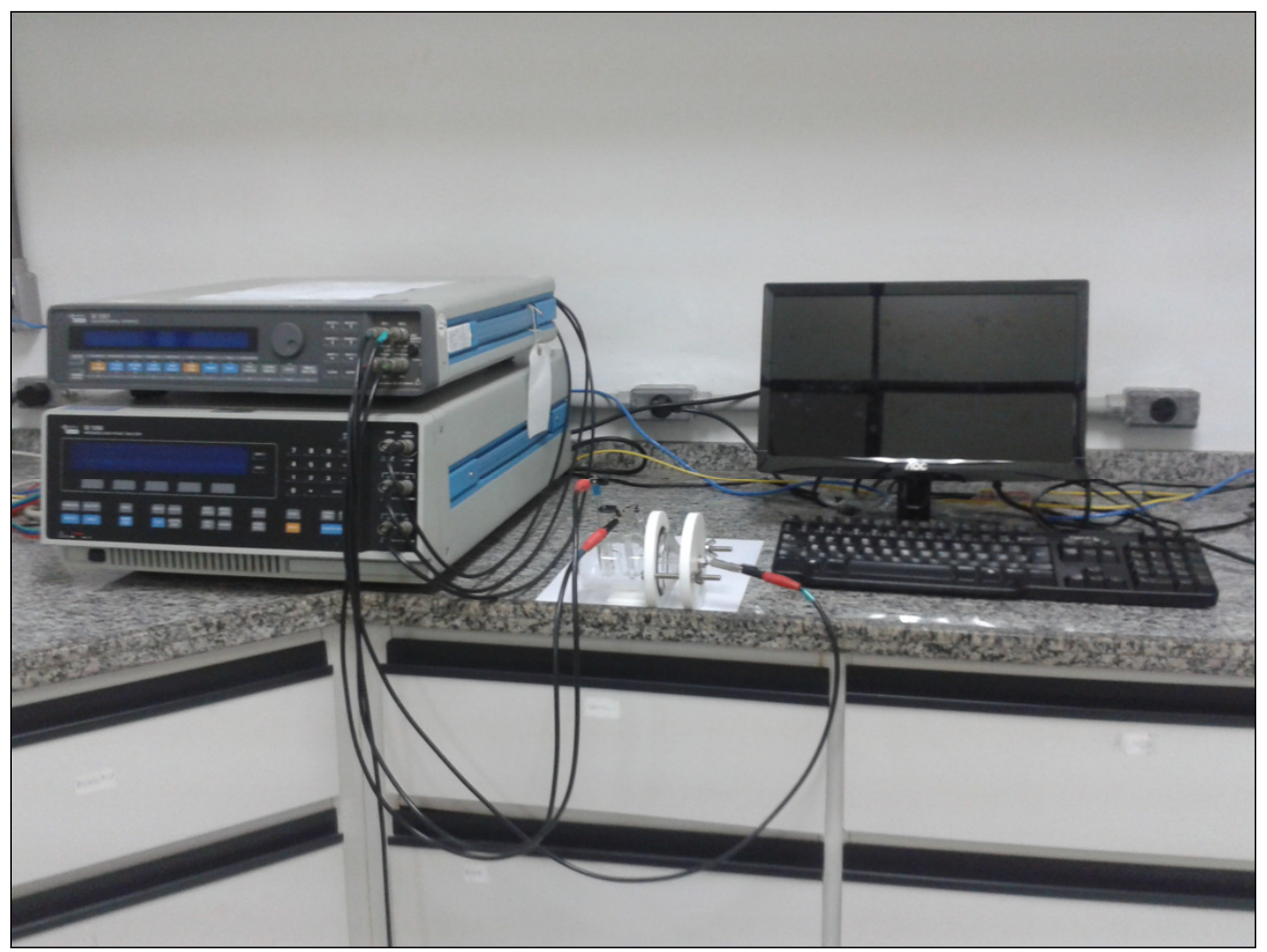

Figura 24 - Potenciostato / Galvanostato Modelo 273A da EG\&G Instruments - Princeton Applied Research conectado a um computador e controlado pelo programa Corrosion Measurement \& Analysis Software (352/252).

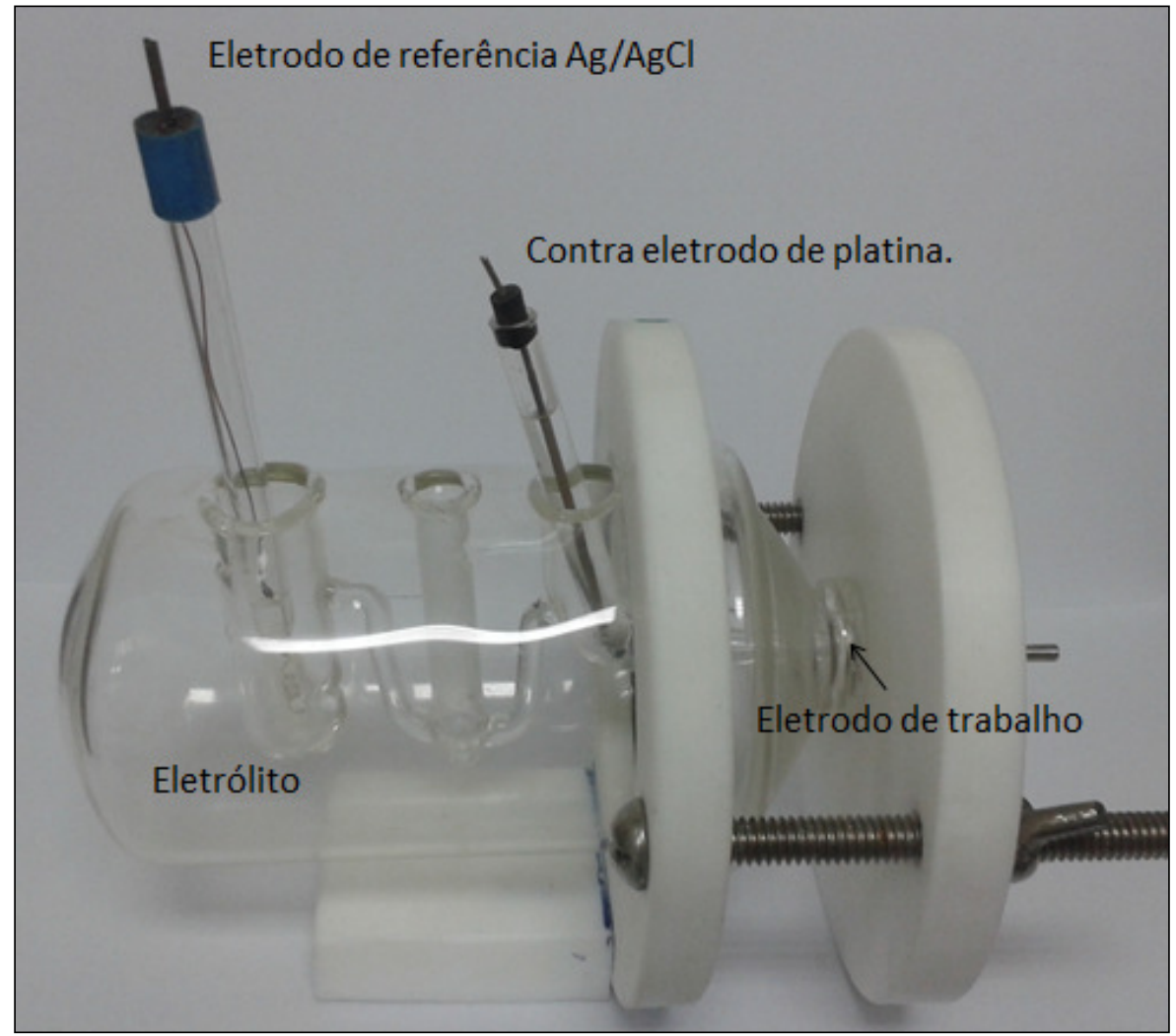

Figura 25 - Célula eletroquímica com eletrodo de calomelano saturado como eletrodo de referencia de $\mathrm{Ag} / \mathrm{AgCl}$ e um contra eletrodo de platina. 


\subsection{Técnicas para caracterização dos produtos de corrosão e morfologia das} superfícies.

As amostras utilizadas nos ensaios de imersão foram avaliadas utilizando-se as técnicas de microscopia óptica (MO) e microscopia eletrônica de varredura (MEV). Os equipamentos utilizados foram um microscópio óptico Olympus para registro de imagem e um microscópio eletrônico de varredura da marca Quanta modelo FEI 600, com analisadores por espectroscopia de energia dispersiva EDS e “Wave Disperseve X-Ray" (WDX), apresentado na figura 26. As micrografias eletrônicas de varredura apresentadas foram obtidas por imagens de elétrons retroespalhados (BSE). Um gerenciador e analisador de imagem, conhecido como AQUINTO, foi utilizado para realização de medições de espessura do produto de corrosão formado na superfície.

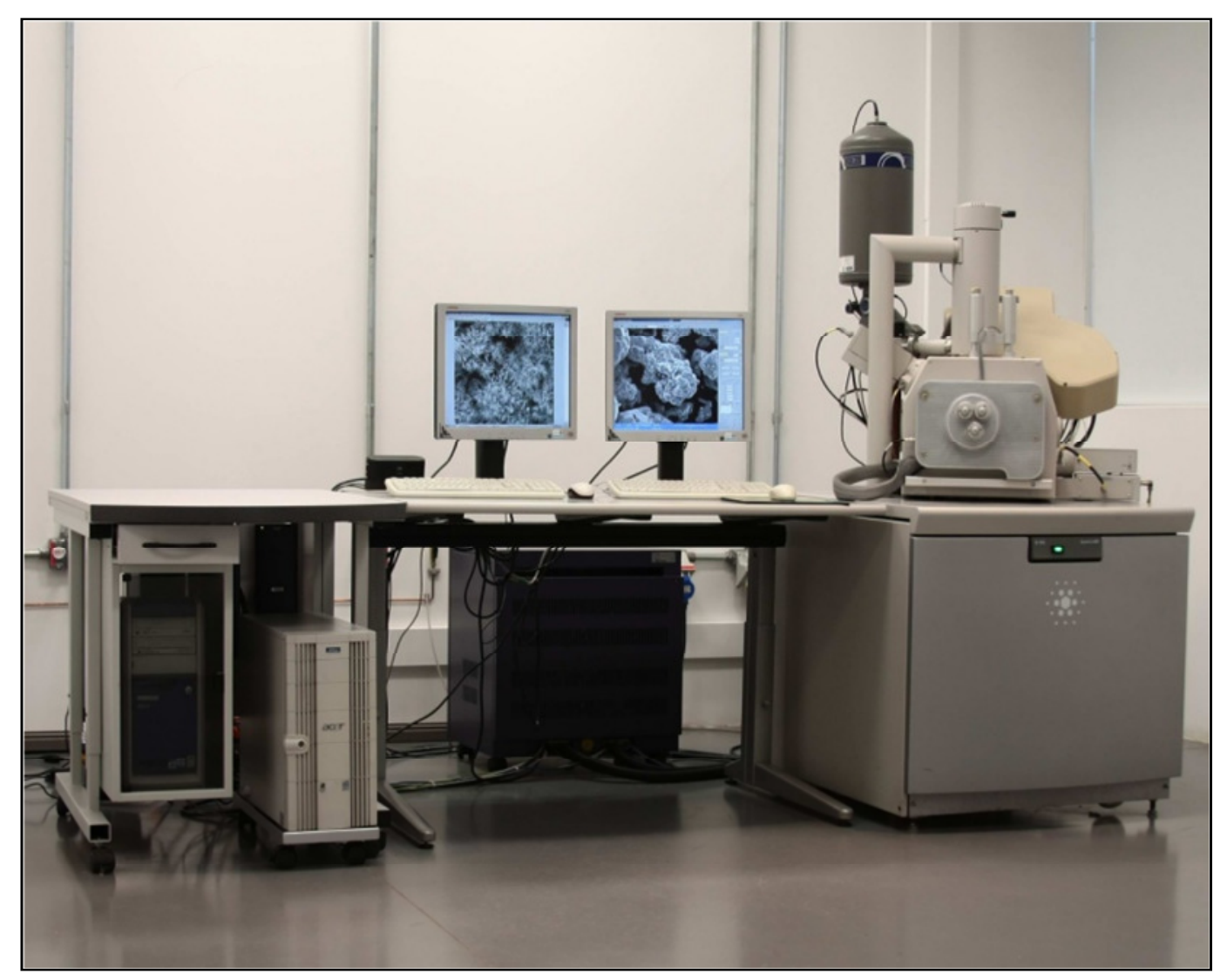

Figura 26 - Microscópio eletrônico de varredura Quanta 600FEI. 


\section{RESULTADOS E DISCUSSÕES}

Neste capítulo são apresentados e discutidos os resultados tanto de caracterização microestrutural como dos ensaios de imersão e eletroquímicos conduzidos em meio de condensado natural, condensado sintético e, no caso dos ensaios eletroquímicos, em solução de cloreto de sódio $0,1 \mathrm{~mol} \mathrm{~L}^{-1}$.

\subsection{Análise química das amostras de ligas de ferro fundido}

Amostras das ligas de ferro fundido com microestrutura perlítica e bainítica foram analisadas quimicamente, com o objetivo de se verificar se ambas estavam de acordo com as especificações, conforme apresentado na tabela 6 . Nota-se uma diferença significativa no teor de fósforo entre os dois materiais, onde o material perlítico apresenta maior teor deste elemento em comparação ao material bainítico. Os teores de fósforo entre $(0,35$ e 0,50$) \%$ em massa, proporcionam melhores propriedades mecânicas ao material perlítico, devido à formação da fase dura "steadita", (CHIAVERINI, 1988).

Tabela 6 - Análise química (\% em massa dos elementos) dos ferros fundidos cinzento estudados neste trabalho.

\section{Elemento Ferro Fundido Perlítico Ferro Fundido Bainítico}

$\begin{array}{ccc}\text { Carbono } & 3,30 & 3,10 \\ \text { Enxôfre } & 0,03 & 0,045 \\ \text { Silício } & 2,05 & 2,20 \\ \text { Manganês } & 0,75 & 0,50 \\ \text { Fósforo } & 0,45 & 0,06 \\ \text { Cromo } & 0,30 & 0,20 \\ \text { Níquel } & -- & 1,30 \\ \text { Molibdênio } & 0,35 & 1,25 \\ \text { Cobre } & -- & --\end{array}$


Outros dois elementos que apresentam uma diferença significativa entre os materiais são o níquel e molibdênio, onde ambos mostram-se maiores no material bainítico em comparação ao perlítico. O níquel e o molibdênio são por vezes utilizados para aumentar a resistência à corrosão das ligas de ferro fundido. O níquel é elemento de importância fundamental na resistência à corrosão destas ligas, devido à formação de um filme de óxido na superfície do material. O molibdênio é um elemento que aumenta a resistência à corrosão em ambientes com presença de ácido clorídrico. Em teores acima de $1 \%$ e combinado com altos teores de silício, aumenta significamente à resistência a corrosão dos ferros fundidos (ASM HANDBOOK, 1996).

\subsection{Análise química do condensado natural.}

O condensado natural, coletado conforme descrito no item 3.1, foi analisado quimicamente e a composição deste está apresentada tabela 7 .

Tabela 7 - Composição química do condensado natural coletado na bancada de teste de emissões ( $\mathrm{pH}=3,5$ e condutividade $26 \mu \mathrm{S} / \mathrm{cm}$ )

\begin{tabular}{cc}
\hline Componentes & Concentração \\
\hline Fluoreto & $0,5 \mathrm{ppm}$ \\
Cloreto & $0,7 \mathrm{ppm}$ \\
Nitrato & $12 \mathrm{ppm}$ \\
Fosfato & $11 \mathrm{ppm}$ \\
Sulfato & $26 \mathrm{Pm}$ \\
\hline
\end{tabular}

O íon encontrado em maior concentração no condensado natural foi o sulfato, com concentração da ordem de $26 \mathrm{ppm}$. Este teor foi considerado relativamente alto comparado com os outros íons, tais como cloreto $(0,7 \mathrm{ppm})$ e nitrato (12 ppm), presentes no condensado, e baixo quando se compara com um condensado sintético no qual a concentração pode ser cerca de 100 vezes maior.

Outras características analisadas foram $\mathrm{pH}$ e condutividade. Embora o $\mathrm{pH}$ da solução seja baixo ( $\mathrm{pH}=3,5)$, a condutividade encontrada também foi baixa $(\mathrm{k}=26 \mu \mathrm{S} / \mathrm{cm})$. Este efeito devido à baixa concentração dos íons no meio, conforme mostra a tabela 5 . Outro efeito da baixa condutividade do condensado é 
o fato da presença de ácidos orgânicos como relatado por HIRAI, (2009) em suas avaliações dos produtos de combustão provenientes do diesel.

Apesar da baixa condutividade apresentada pela solução foram realizadas tentativas de uso desta solução (condensado natural) nos ensaios eletroquimicos de corrosão, especificamente de espectroscopia de impedância eletroquímica (EIE). A alta impedância do meio dificultou a obtenção de resultados confiáveis sobre o comportamento eletroquímico da interface ferro fundido-meio.

\subsection{Caracterização da microestrutura das amostras de ferro fundido}

As análises da microestrutura dos materiais estudados por microscopia de varredura eletrônica (MEV) foi realizada com o objetivo de investigar as fases presentes nas ligas, bem como suas características estruturais. As figuras 27 e 28 apresentam as imagens de composição e relevo, realizadas por MEV, das amostras de ferro fundido estudadas neste trabalho, com microestrutura perlítica e bainítica, após o ataque químico em solução de nital $3 \%$. Segundo as normas Mahle D2623 e DIN-EN-ISO-945 que estabelecem a característica de composição e microestrutura do ferro fundido perlítico. A microestrutura deve ser composta por uma matriz perlítica, uma fase eutética fosforosa conhecida como "steadita", precipitados de sulfeto de manganês e grafitas do tipo A (grafitas distribuídas de forma uniforme com orientação irregular e lamelas finas) e B (grafitas com agrupação em rosetas com orientação irregular, centro formado por grafita fina e as bordas com grafitas grossas), ambas distribuídas em toda matriz, conforme apresentado na figura 29.

A norma Mahle F4027 e a norma similar DIN-EN-ISO-945, estabelecem as características de composição e microestrutura do ferro fundido bainítico, no qual a microestrutura deve ser composta por uma matriz de perlita fina conhecida como bainita, precipitados de carboneto, sulfeto e grafitas do tipo A (grafitas distribuídas de forma uniforme com orientação irregular e lamelas finas), D (grafitas com segregação interdendrítica e com orientação irregular), e E (grafitas com segregação interdendrítica orientada e veios finos), conforme ilustrado na figura 30 . 

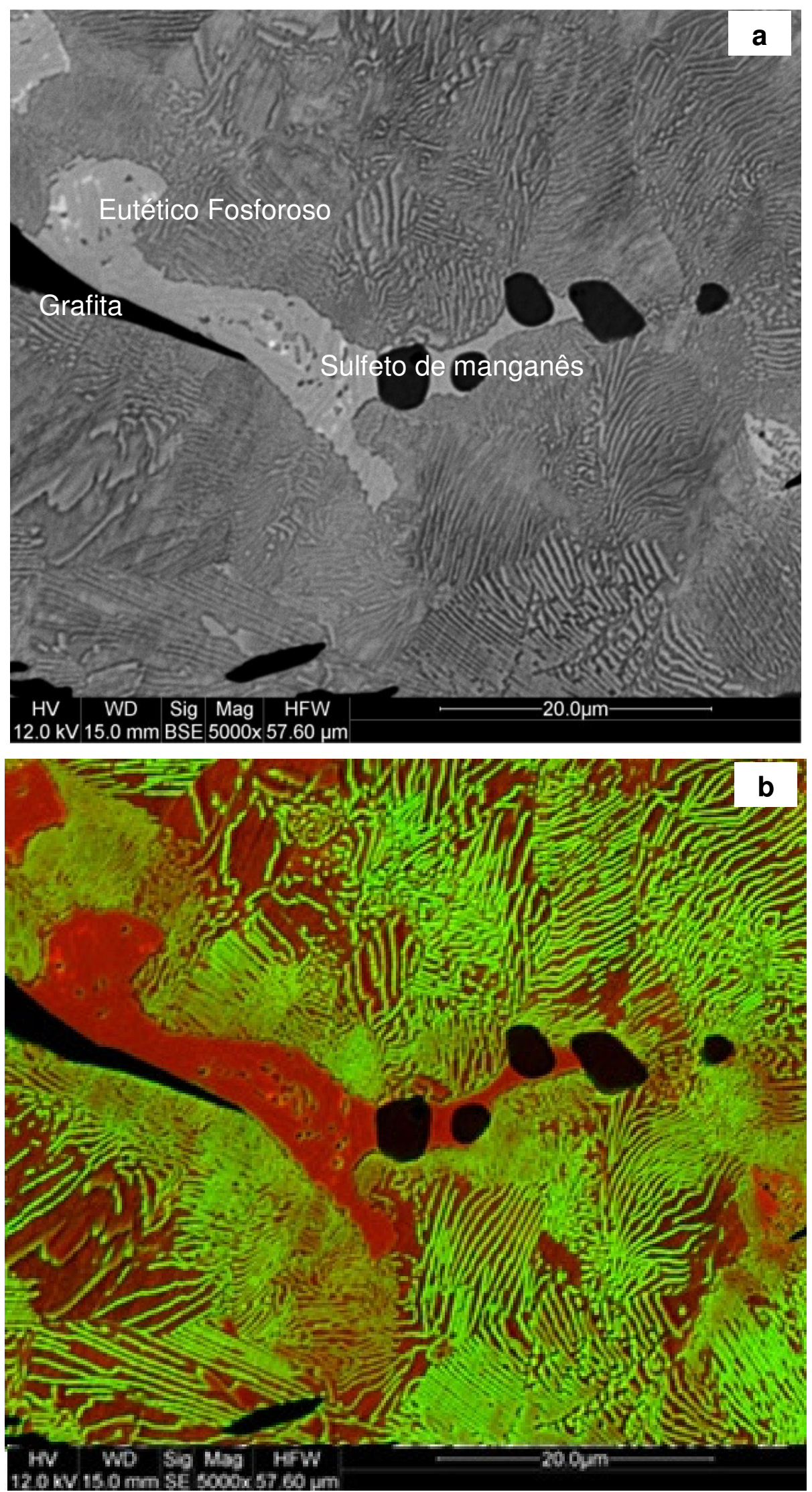

Figura 27 - Micrografias por MEV do ferro fundido cinzento perlítico após ataque com nital $3 \%$. (a) Imagem de elétrons retro espalhados (BSE) e (b) de elétrons secundários (SE), mostrando o relevo da superfície da amostra. 

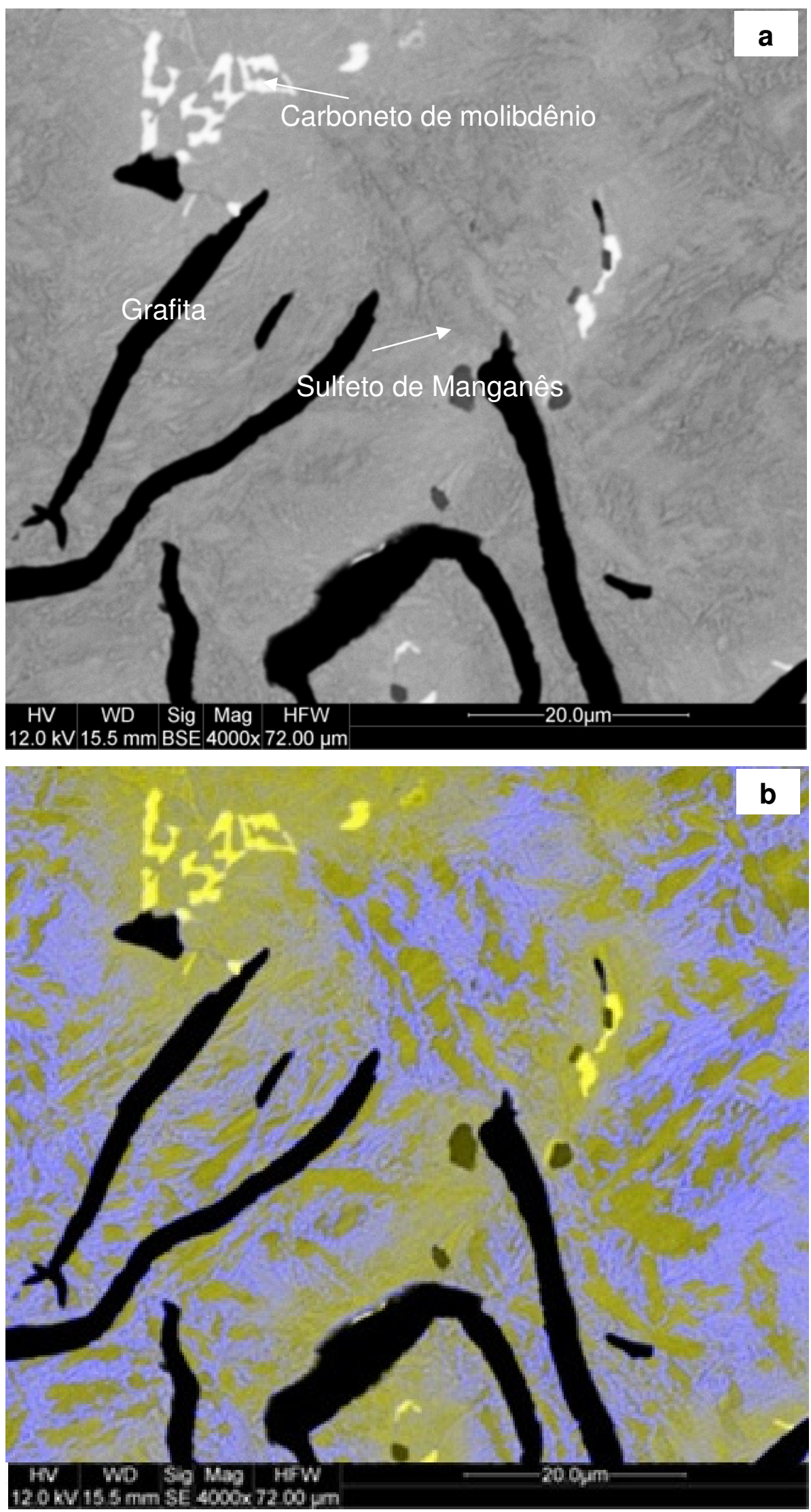

Figura 28 - Micrografias por MEV do ferro fundido cinzento bainítico após ataque com nital $3 \%$. (a) Imagem de elétrons retro espalhados (BSE) e (b) de elétrons secundários (SE), mostrando o relevo da superfície da amostra. 


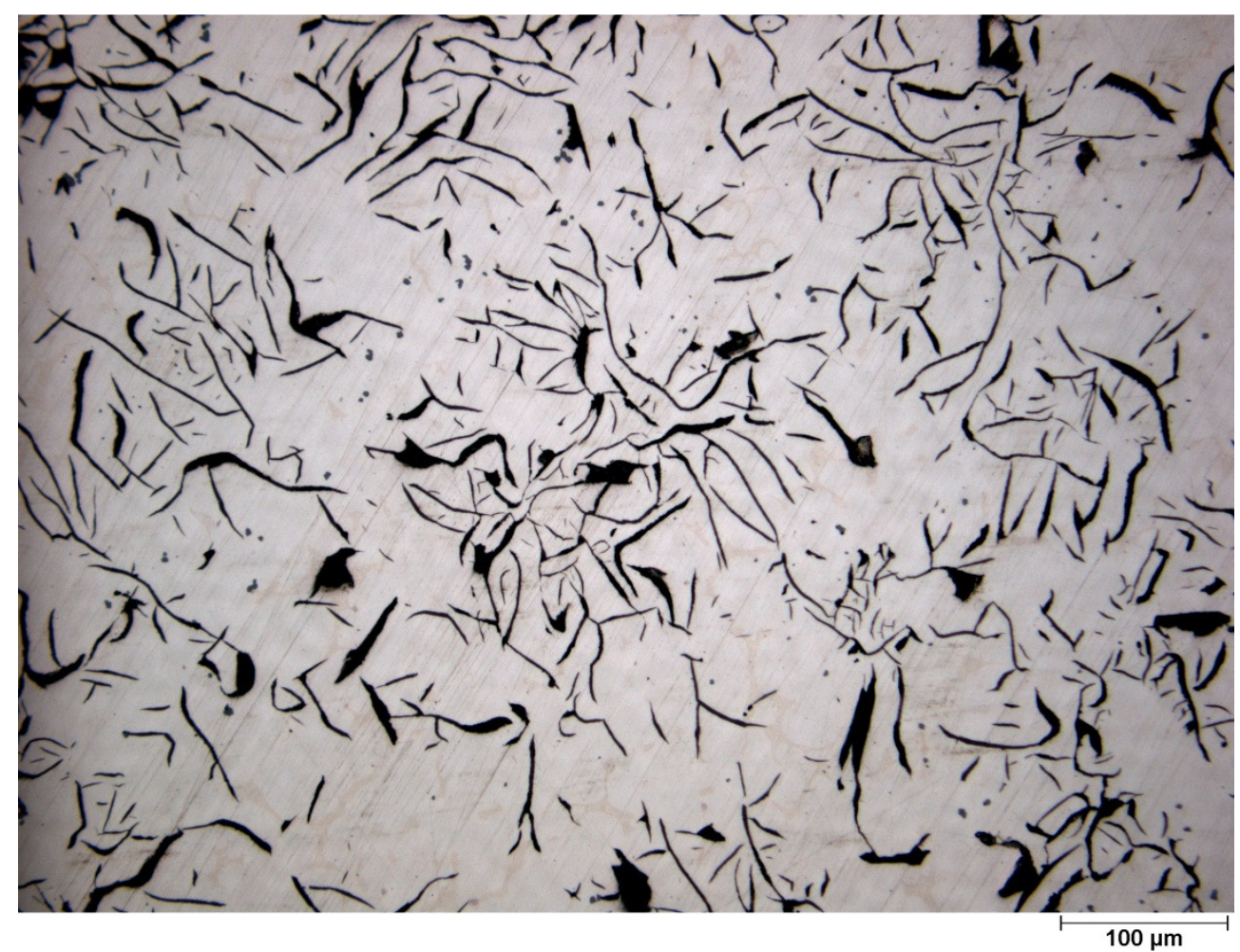

Figura 29 - Grafitas no material perlítico do tipo A distribuídas de forma uniforme com orientação irregular e lamelas finas e tipo B com agrupação em rosetas com orientação irregular, centro formado por grafita fina e as bordas com grafitas grossas, ambas distribuídas em toda matriz.

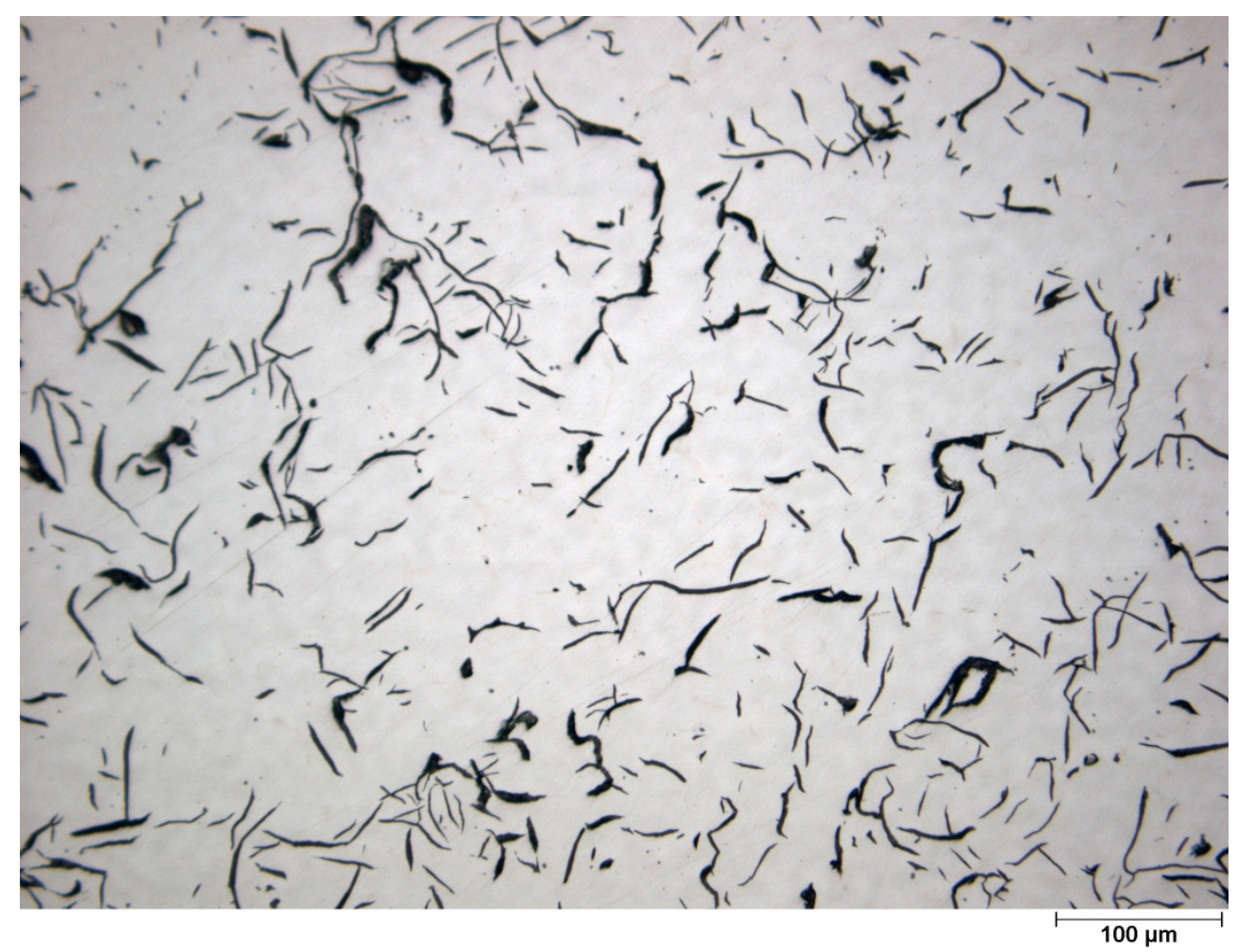

Figura 30 - Grafitas no material bainítico do tipo A distribuídas de forma uniforme com orientação irregular e lamelas finas, tipo D com segregação interdendrítica e com orientação irregular e E com segregação interdendrítica orientada e veios finos. 
As análises semi-quantitativas por espectroscopia de energia dispersiva (EDS) das fases presentes nos materiais perlítico e bainítico são apresentadas nos espectros mostrados nas figuras 31 e 32 , respectivamente.
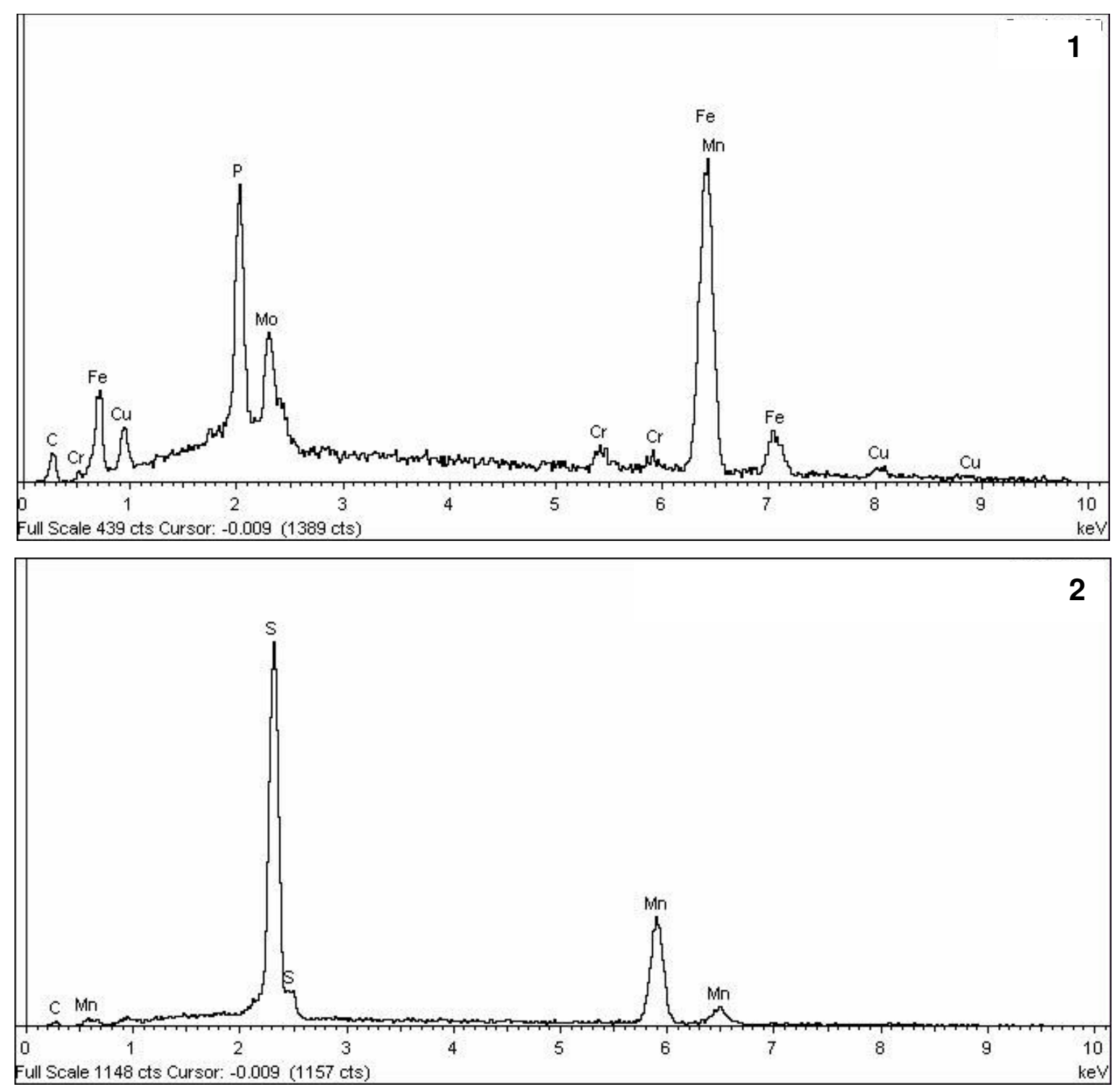

Figura 31 - Análise semi-quantitativa por espectroscopia de energia dispersiva (EDS) de fases no material perlítico. Espectro 1 - Eutético fosforoso "Steadita"; Espectro 2 Sulfeto de Manganês. 

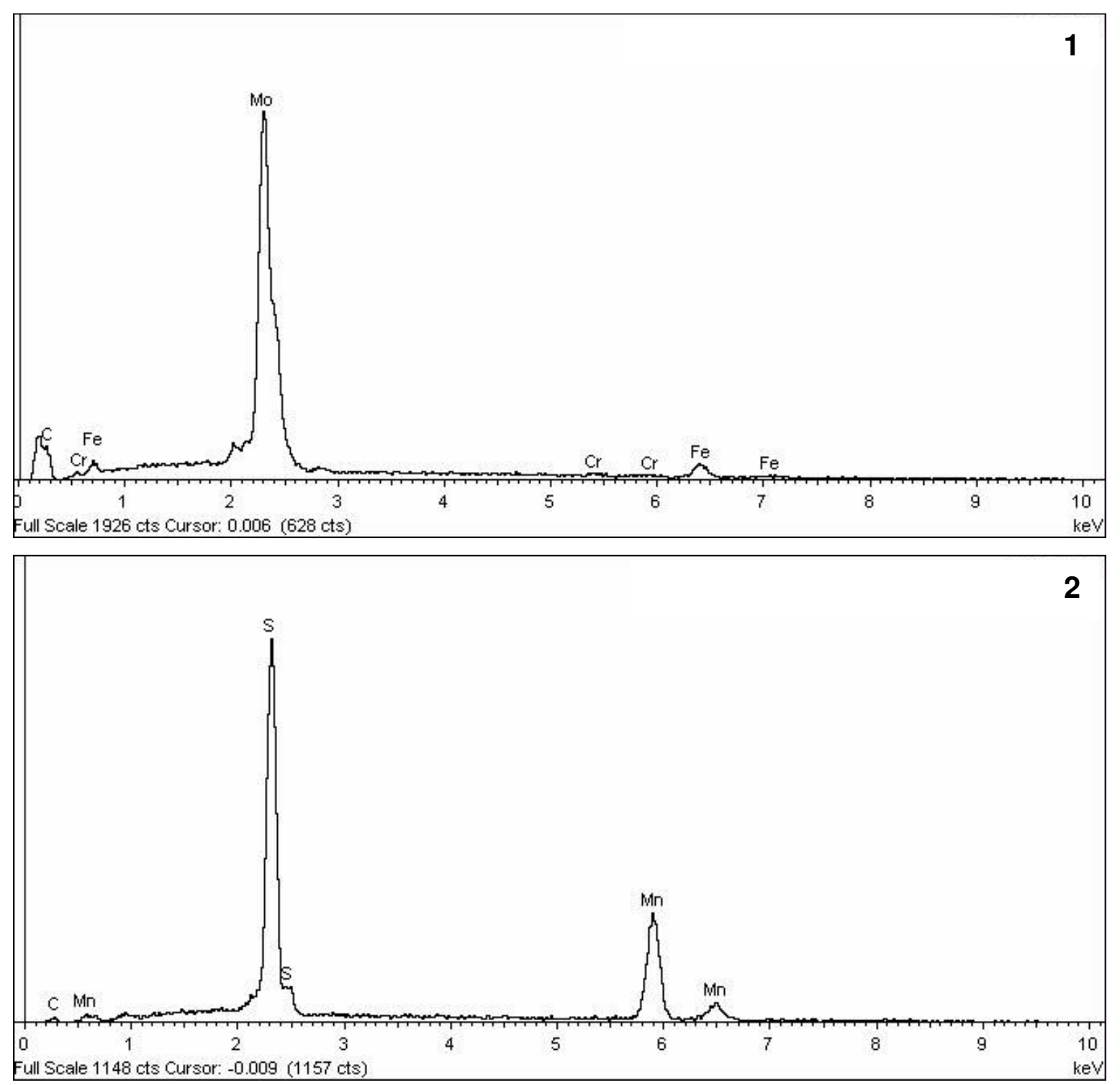

Figura 32 - Análise semi-quantitativa por espectroscopia de energia dispersiva (EDS) de fases no material bainítico. Espectro 1 - Carboneto de molibdênio; Espectro 2 - Sulfeto de Manganês.

\subsection{Ensaios de imersão e caracterização da superfície pós ensaios por MEV}

Os ferros fundidos estudados de microestrutura perlítica e bainítica, foram imersos em meio de condensado sintético K1.1, especificado na norma VDA 230-214 por até $60 \mathrm{~h}$ de imersão. Durante este período foram realizadas três retiradas das amostras para análise. A evolução do ataque corrosivo foi observada em uma mesma região, conforme ilustrado nas figuras 33 e 34 . As análises de imagens de elétrons retro espalhados (BSE) mostraram as fases que permaneceram pouco afetadas pelo menos durante todo o ensaio. Em ambos os materiais ensaiados, o ataque corrosivo mais acentuado ocorre na matriz, e a grafita permanece intacta nos dois tipos de microestrutura, indicando que 0 
mecanismo de corrosão foi a grafitização. Este mecanismo é determinado pelo ataque seletivo da matriz, área anódica, enquanto a grafita, inerte e excelente condutora de elétrons, atua como área catódica, favorecendo a formação de pilhas galvânicas eficientes (CHIAVERINI, 1988).
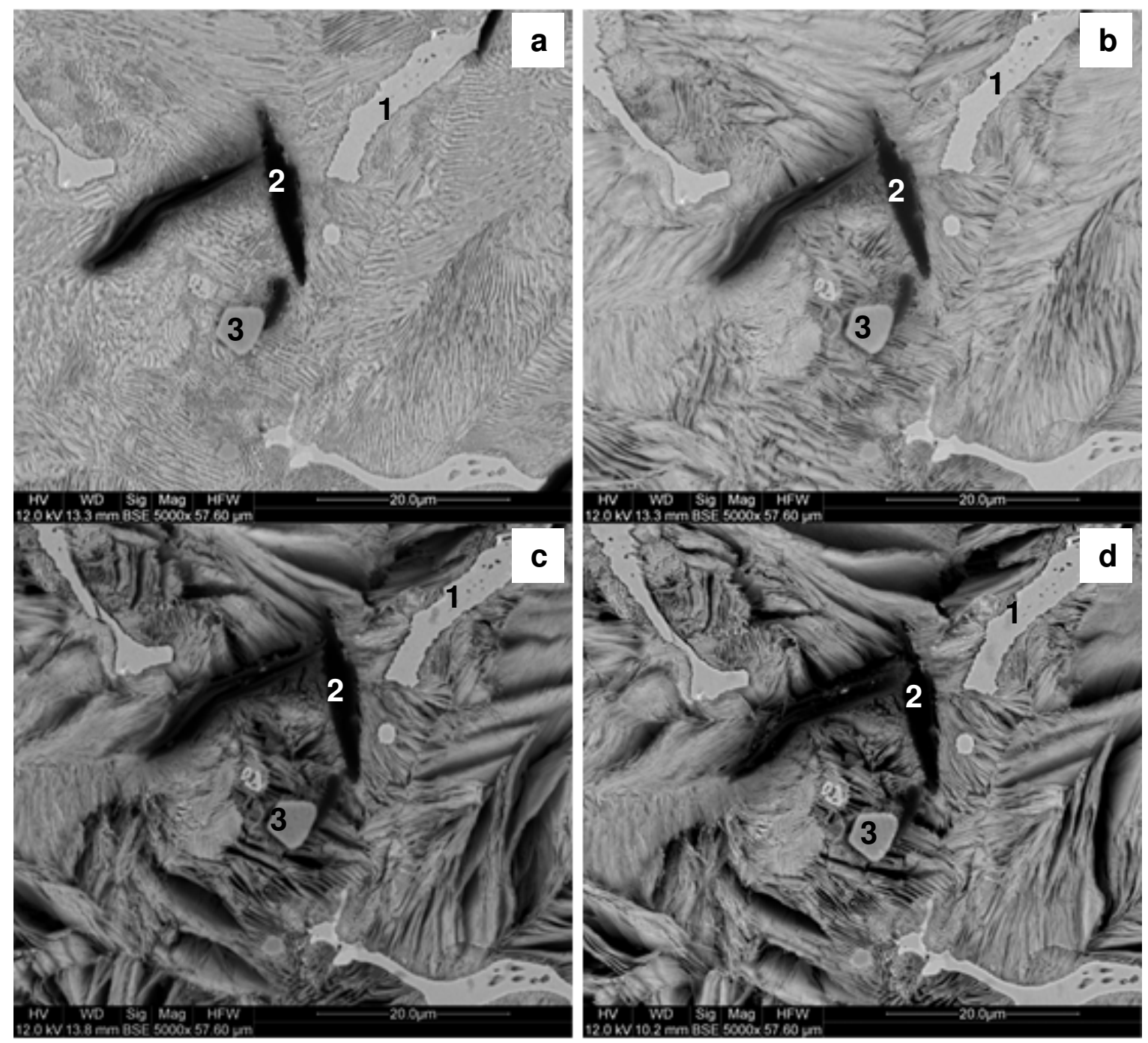

Figura 33 - Micrografias por MEV do ferro fundido perlítico após ataque corrosivo em condensado sintético. Imagens de elétrons retro espalhados (BSE) (a) antes da imersão; (b) após 2 h; (c) após 20 h; (d) após 60 h de imersão. 

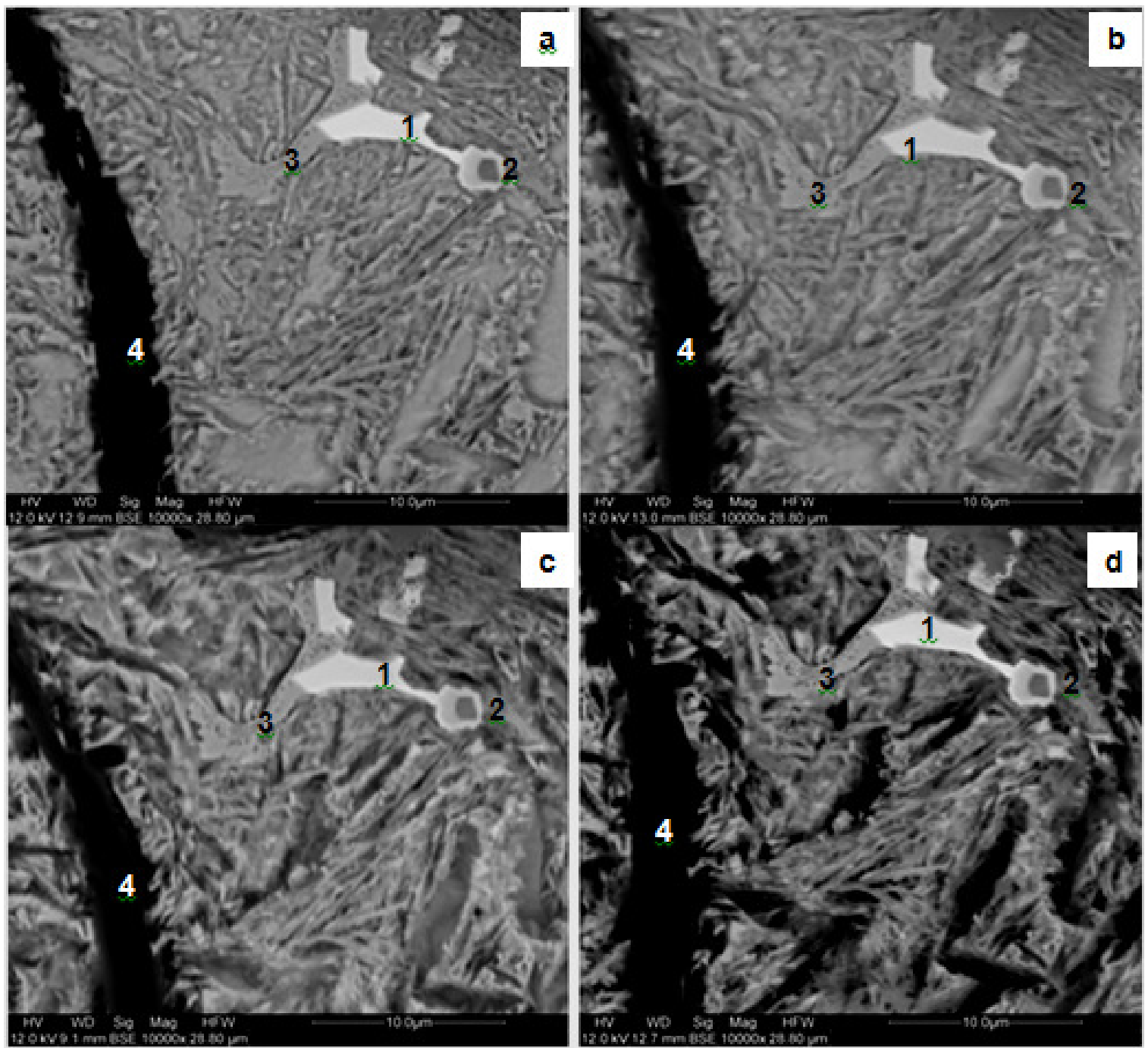

Figura 34 - Micrografias por MEV do ferro fundido cinzento bainítico antes e após imersão em condensado sinttico. Imagens de elétrons retro espalhados (BSE). (a) Antes da imersão; e após (b) 2 h; (c) 20 h; (d) 60 h de imersão.

Os espectros de energia dispersiva (EDS) mostrados nas figuras 35 e 36 identificaram a composição semi-quantitativa das fases que resistiram ao ataque corrosivo após $60 \mathrm{~h}$ de imersão. 

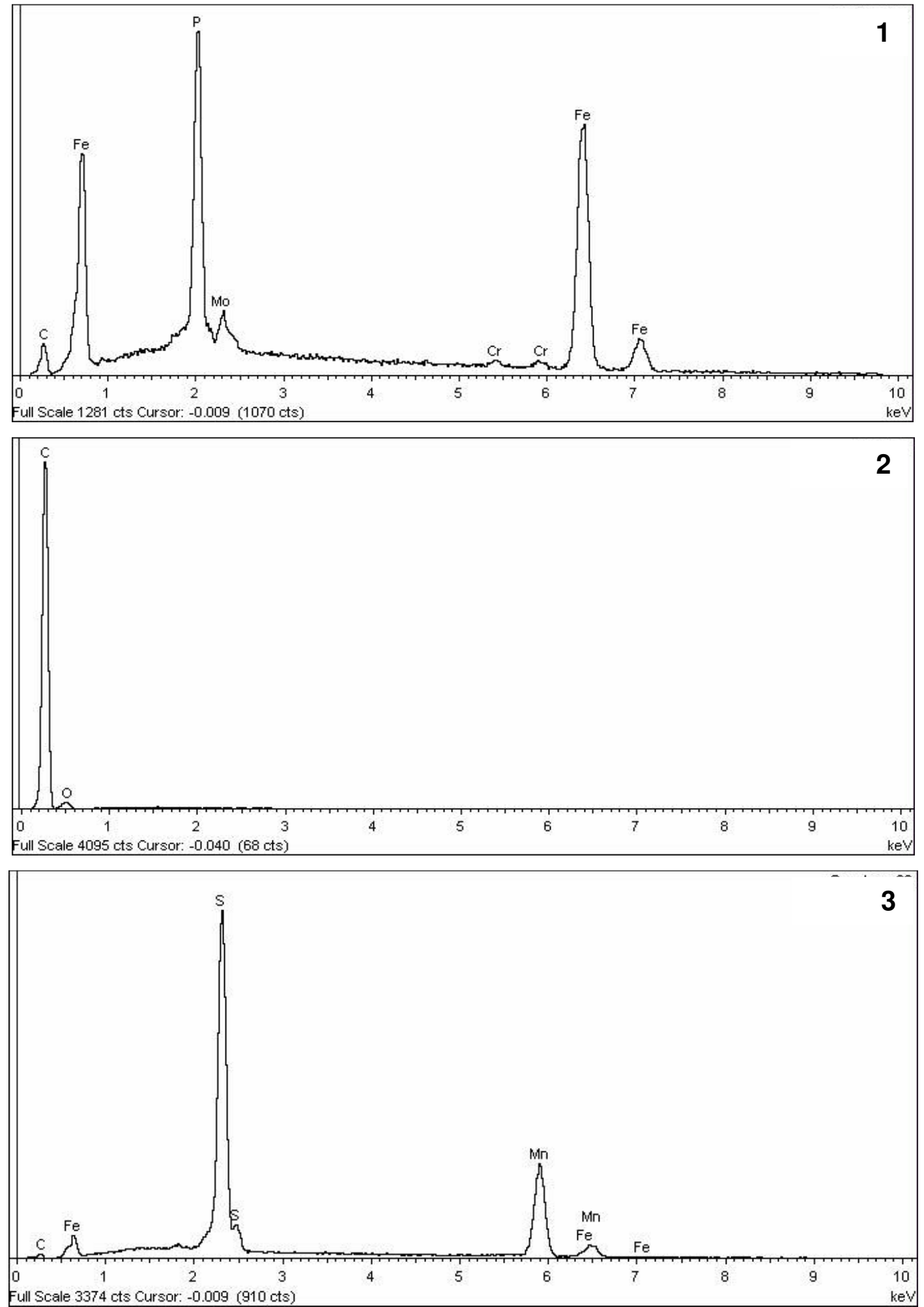

Figura 35 - Análise semi-quantitativa por espectroscopia de energia dispersiva (EDS) das várias fases no ferro fundido perlítico indicadas por números na Figura 29. Espectro 1 "Steadita"; espectro 2 - Grafita; espectro 3 - Sulfeto de Manganês. 

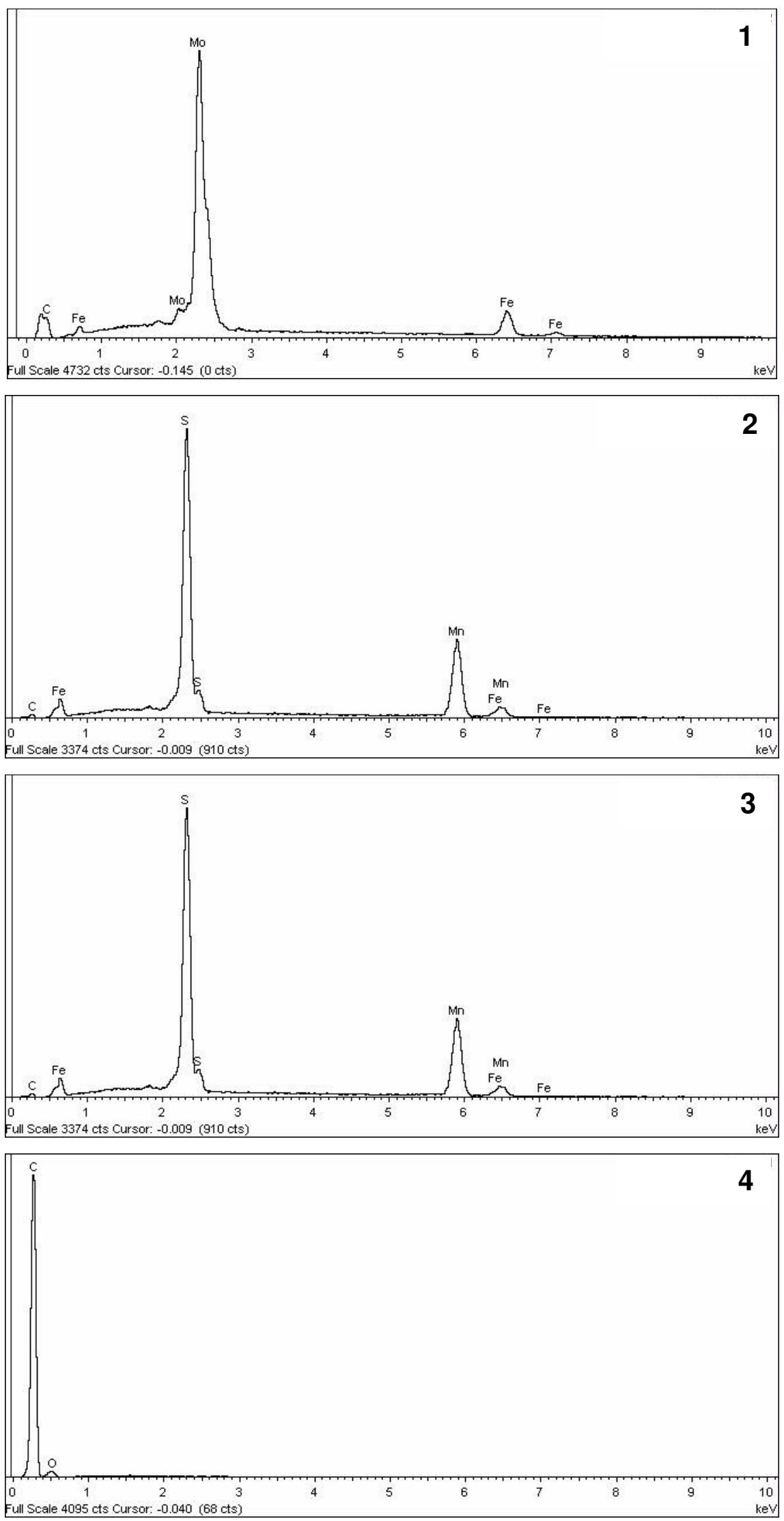

Figura 36 - Análise semi-quantitativa por espectroscopia de energia dispersiva (EDS) de várias fases no ferro fundido bainítico, indicadas por números na Figura 31. Espectro 1 Carboneto de Molibdênio; espectro 2 - Sulfeto de Manganês; espectro 3 - "Steadita"; espectro 4 - Grafita. 
O mecanismo eletroquímico de grafitização causa o ataque localizado e destrutivo da matriz de ferrita ( $\alpha-\mathrm{Fe})$, com o ferro se oxidando e indo para a solução, de acordo com a reação 1 (GENTIL, 1994).

$$
\mathrm{Fe} \rightarrow \mathrm{Fe}^{2+}+2 \mathrm{e}^{-}
$$

Nas áreas catódicas, regiões onde se localiza a grafita, ocorre a redução de agentes oxidantes do meio corrosivo. As duas principais reações catódicas são as de evolução de hidrogênio e de redução do oxigênio, em meios ácidos e neutros aerados, respectivamente, as quais são indicadas nas reações 2 e 3, respectivamente (GENTIL, 1994):

$$
\begin{gathered}
2 \mathrm{H}^{+}+2 \mathrm{e}^{-} \rightarrow \mathrm{H}_{2} \\
\mathrm{O}_{2}+2 \mathrm{H}_{2} \mathrm{O}+4 \mathrm{e}^{-} \rightarrow 4 \mathrm{OH}^{-}
\end{gathered}
$$

No material perlítico, nota-se que a steadita, fase eutética fosforosa, e 0 sulfeto de manganês, apresentam elevada resistência à corrosão, mantendo-se intactos após $60 \mathrm{~h}$ de imersão. No caso do material bainítico, além da steadita e do sulfeto de manganês, o carboneto de molibdênio manteve-se intacto durante todo o tempo em que ficou imerso na solução. O mecanismo de corrosão em um ferro fundido de microestrutura perlítica, com a presença da fase ferrítica e da fase eutética fosforosa ("steadita"), apresenta o início da corrosão, sempre nas regiões da interface entre a grafita e as outras fases, sendo este o menor caminho para condução eletrônica. A literatura relata que as demais fases presentes sofrem corrosão conforme a ordem de reatividade, com a fase eutética fosforosa sendo a última a sofrer corrosão (MOHEBBI, 2011).

Nas figuras 37 e 38 mostram imagens de elétrons secundários (SE) para os materiais perlítico e bainítico, onde pode ser notado que a grafita permanece intacta na superfície da matriz de ambos os materiais. Em algumas regiões não é possível identificar facilmente a presença da matriz, devido ao seu intenso ataque, principalmente próximo às grafitas. 

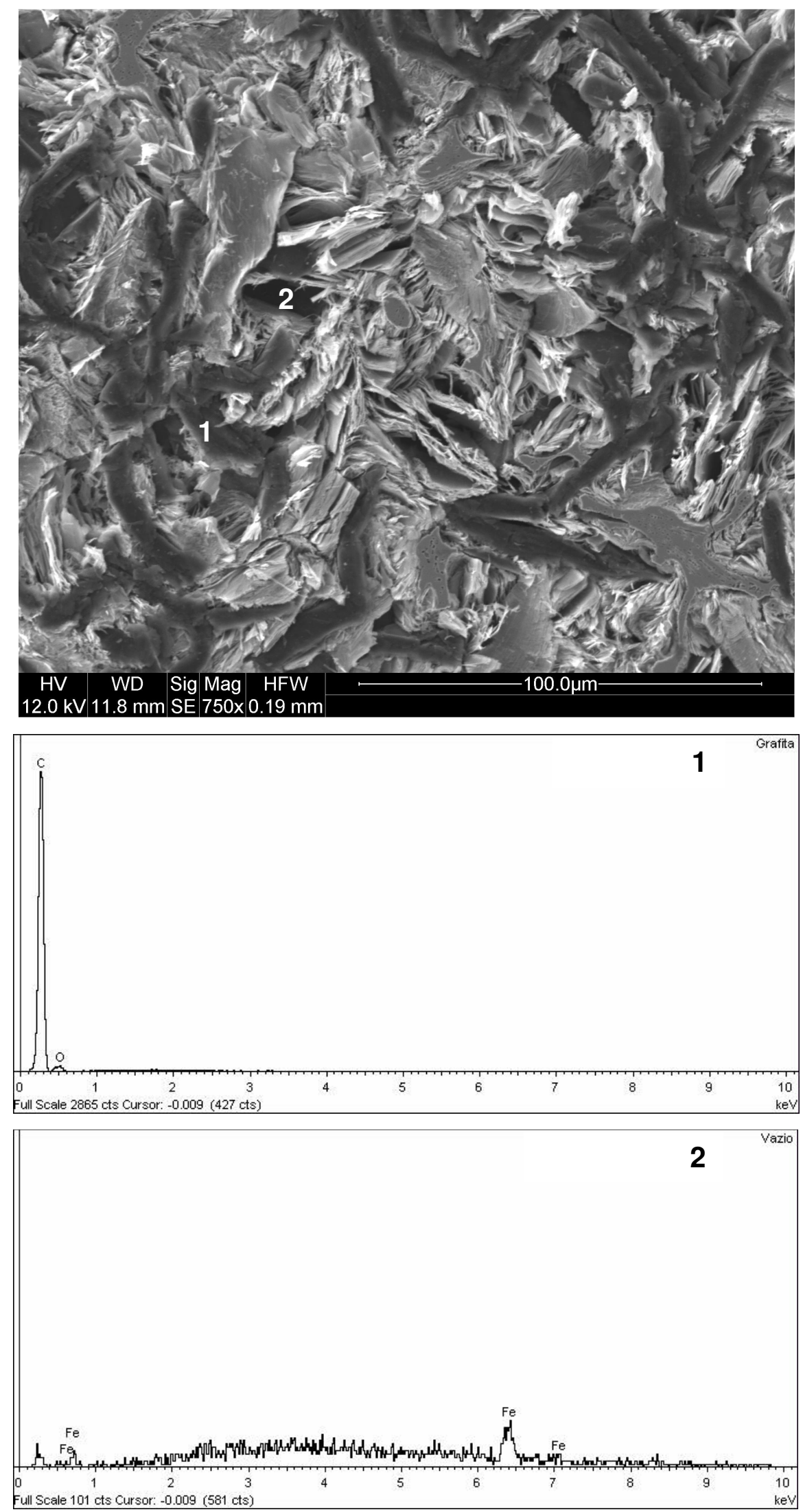

Figura 37 - Micrografia por MEV mostrando imagem de elétrons secundários (SE) da superfície do ferro fundido perlítico após $120 \mathrm{~h}$ de imersão e espectros EDS das áreas marcadas na micrografia como (1) correspondendo à grafita remanescente e (2) região da matriz com ataque corrosivo. 

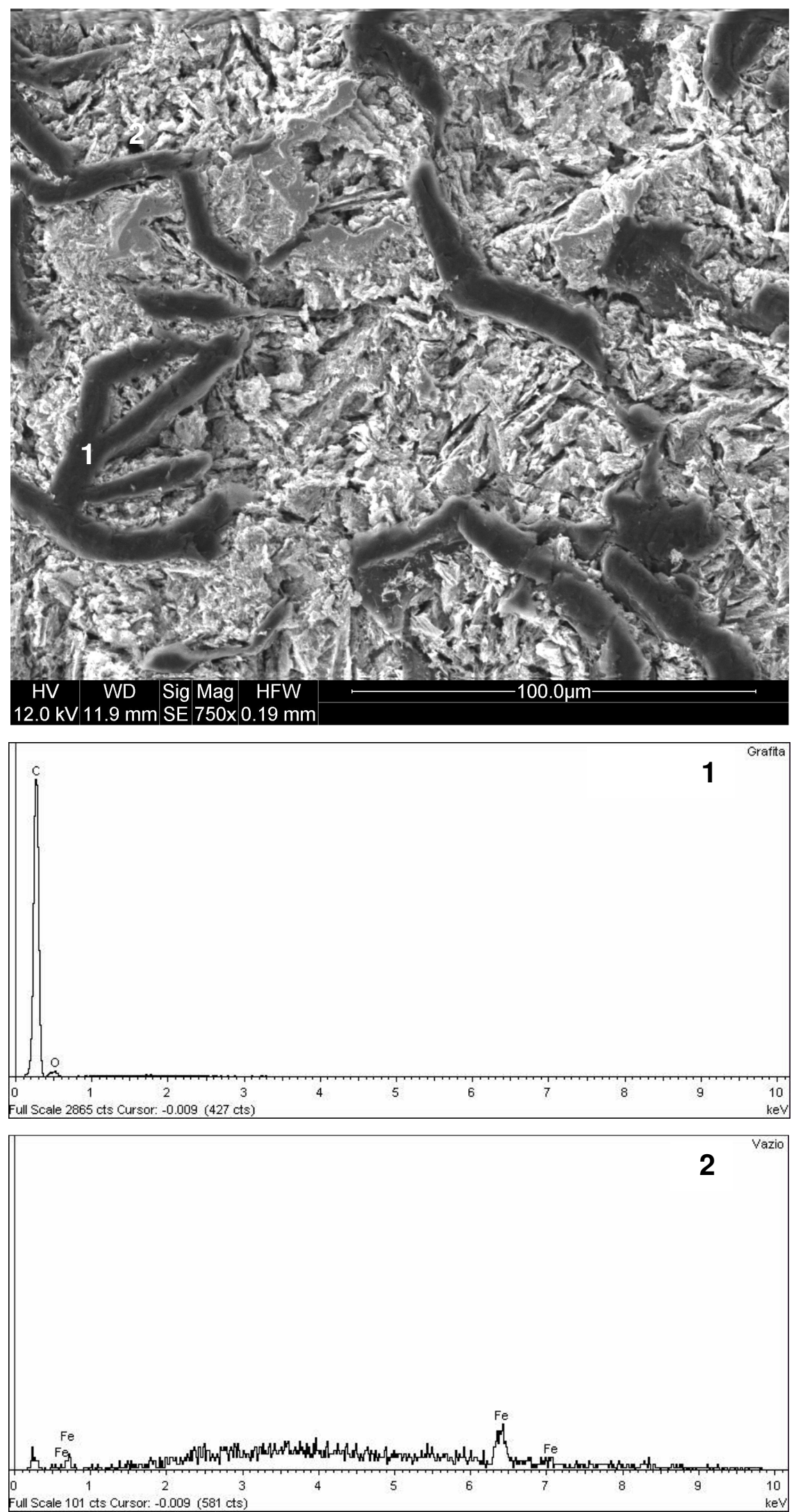

Figura 38 - Micrografia por MEV mostrando imagem de elétrons secundários (SE) da superfície do ferro fundido bainítico após $120 \mathrm{~h}$ de imersão. O espectro EDS 1 corresponde à grafita remanescente e o espectro 2 a região da matriz com ataque corrosivo. 
A quantidade e a forma da grafita nas ligas de ferro fundido tem influência direta na resistência à corrosão destes materiais. A grafita livre induz a formação de produtos de corrosão do ferro e outros elementos de liga. Em caso de aderência destes produtos à superfície metálica há um aumento na resistência à corrosão do material, diminuindo a taxa de propagação do processo corrosivo, uma vez que a camada formada atua como barreira, impedindo o avanço do ataque (AJEEL, 2008).

\subsection{Ensaio de imersão e caracterização pós ensaio por microscopia ótica}

A figura 39 apresenta micrografias por microscopia ótica do material com microestrutura perlítica após os ensaios de imersão em condensado natural. Observou-se durante o ensaio em meio de condensado natural a formação dos produtos de corrosão nas primeiras horas de imersão, indicando a forte atuação corrosiva do meio.
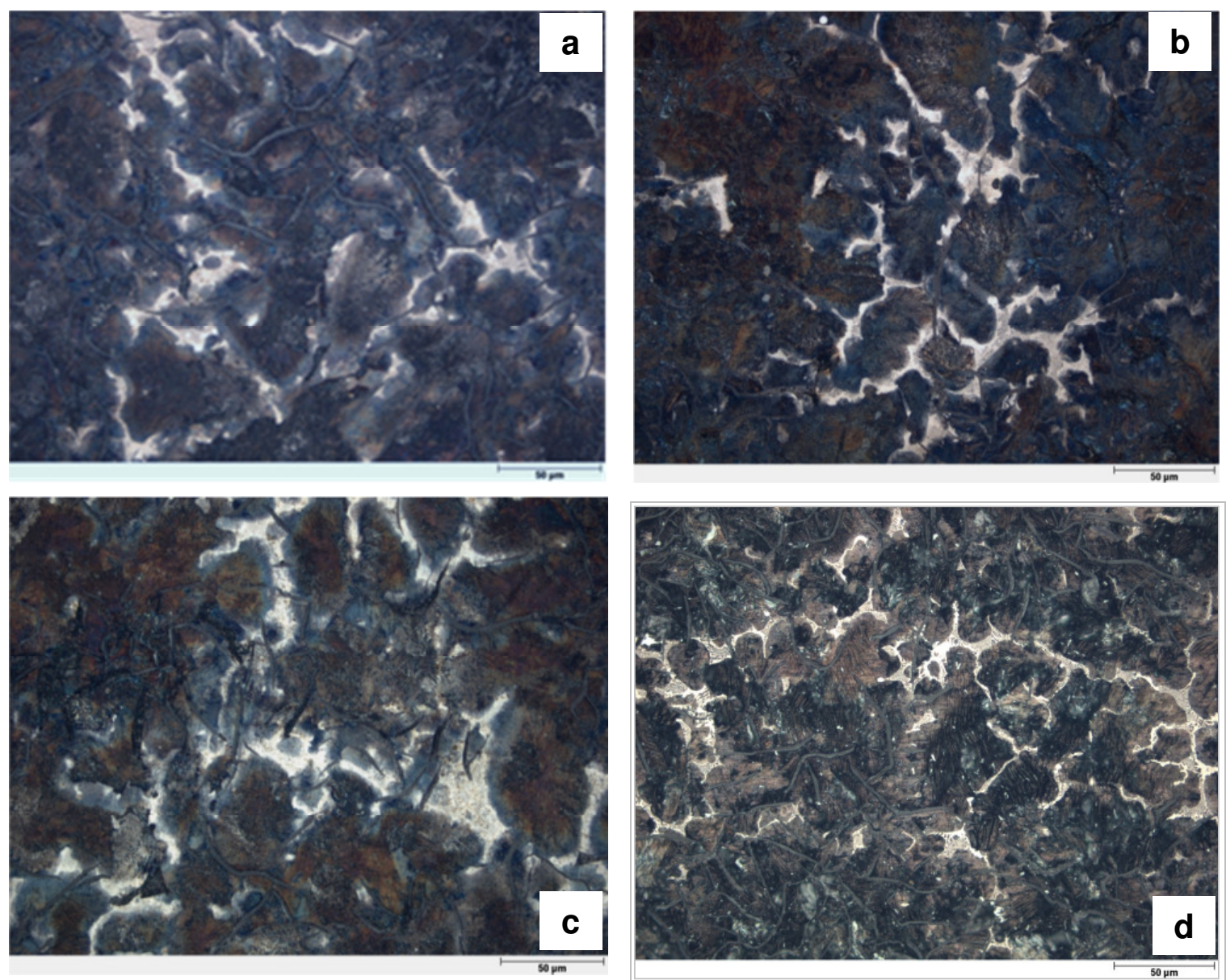

Figura 39 - Imagem por Microscopia Ótica da superfície das amostras do ferro fundido perlítico pós-ensaio de imersão no condensado natural. (a) 2 h, (b) 5 h (c) 16 h e (d) 120 h de imersão. 
O fato da solução de condensando natural apresentar o pH na ordem de 3,5 faixa esta considerada altamente ácida, favoreceu a dissolução do ferro da matriz. Conforme apresentado no diagrama de POURBAIX (1976), no capitulo 3. O composto de colocaração castanho-avermelhada observado na superfície das amostras ensaiadas é caracteristico da formação da ferrugem. A aderência deste composto não foi observada nas amostras.

$\mathrm{Na}$ figura 40 apresentam-se imagens de superfície obtidas por microscopia ótica, das amostras do material com microestrutura perlítica após ensaio de imersão em condensado sintético.
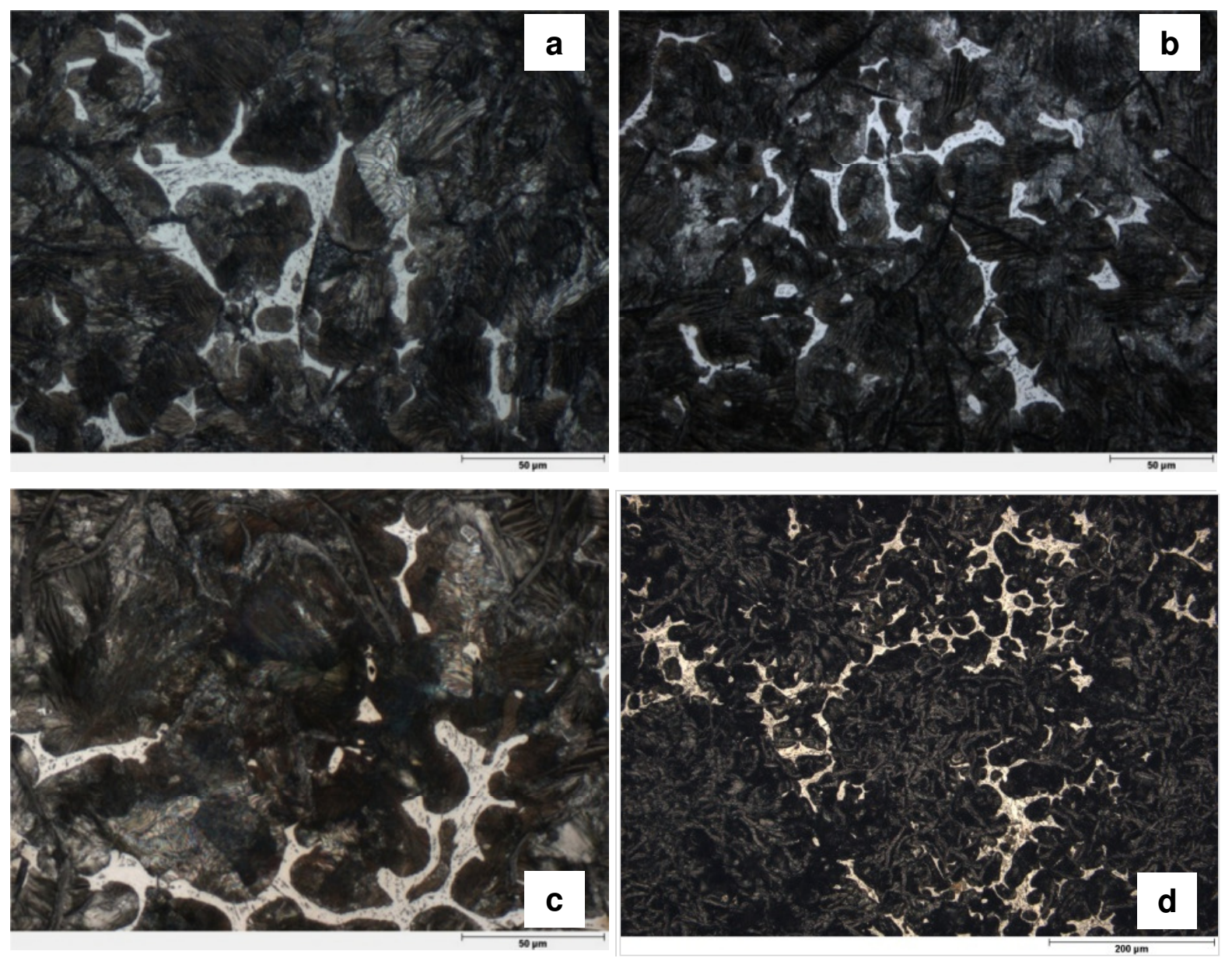

Figura 40 - Imagem por Microscopia Ótica da superfície das amostras do ferro fundido perlítico após ensaio de imersão no condensado sintético. (a) 2 h, (b) 5 h (c) 16 h e (d) $120 \mathrm{~h}$ de imersão.

As amostras de ferro fundido perlítico em meio de condensado sintético, apresentaram um comportamento de corrosão similar ao apresentado pelas amostras ensaiadas com o condensado natural. A diferença observada foi com relação à quantidade de produtos de corrosão formados na superfície das 
amostras, mais intenso nas amostras ensaiados com o condensado sintético. Um forte contraste entre a grafita e a matriz foi notado nas imagens, deixando em evidência a steadita.

$\mathrm{Na}$ figura 41 apresentam-se as imagens de superfície obtidas por microscopia ótica, das amostras do material com microestrutura bainítica após os ensaios de imersão em condensado natural.

Nota-se que o ferro fundido bainítico em meio de condensado natural, apresentou um ataque menos acentuado da matriz em comparação ao ferro fundido perlítico.
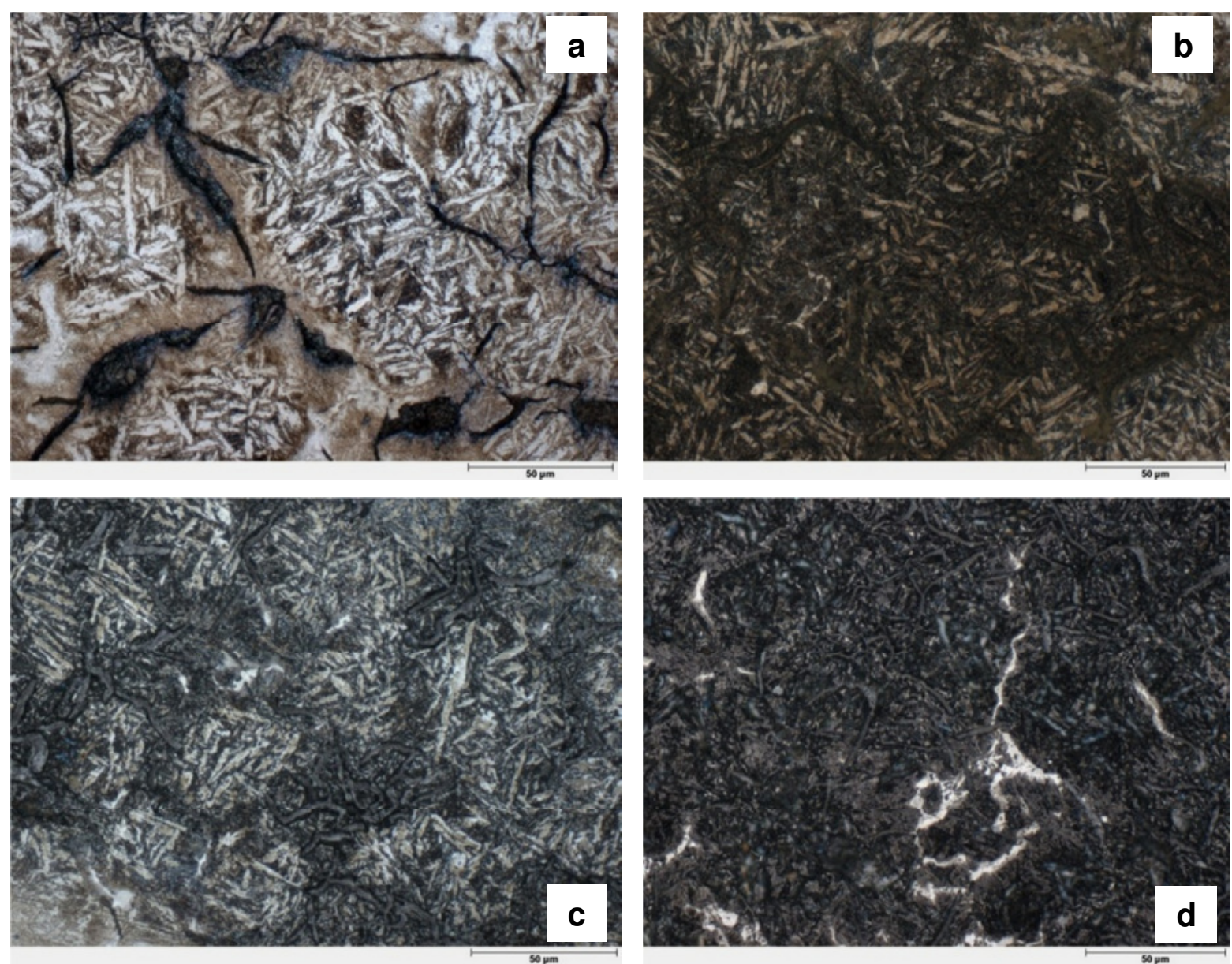

Figura 41 - Imagens por Microscopia Ótica da superfície das amostras do ferro fundido bainítico após ensaio de imersão no condensado natural. (a) 2 h, (b) 5 h, (c) 16 h e (d) $120 \mathrm{~h}$ de imersão.

Observou-se, regiões preservadas na matriz, formando pequenas colmeias, imagens com 5 e $16 \mathrm{~h}$ de imersão. Sugere que nas regiões centrais destas colmeias, a matriz foi preservada do ataque nestes tempos de imersão. Este fato pode ter acontecido devido às reações anodicas e catódicas terem se 
concentrado inicialmente nas regiões próximas as grafitas. No entanto, com $120 \mathrm{~h}$ de imersão não foi observado à formação das colmeias, sendo a amostra completamente coberta com o produto de corrosão de coloração castanhoavermelhada.

$\mathrm{Na}$ figura 42 apresentam-se as imagens de superfície obtidas por microscopia ótica, das amostras do material com microestrutura bainítica após os ensaios de imersão em condensado sintético.
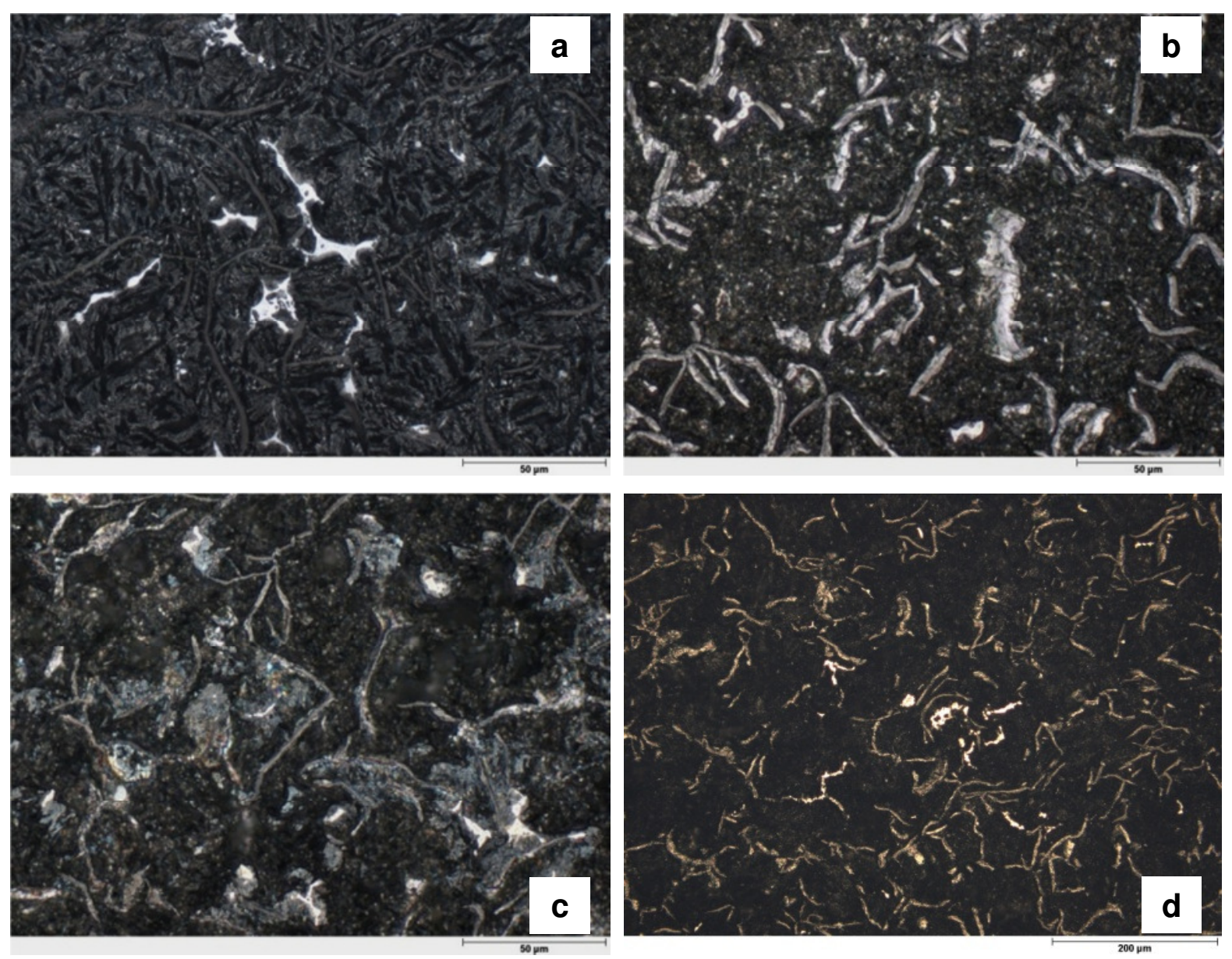

Figura 42 - Imagens por Microscopia Ótica da superfície das amostras do ferro fundido bainítico após ensaio de imersão no condensado sintético. (a) $2 \mathrm{~h}$ e (b) $5 \mathrm{~h}$ de imersão, (c) $16 \mathrm{~h}$ e (d) $120 \mathrm{~h}$ de imersão.

As amostras de ferro fundido bainítico em meio de condensado sintético apresentaram um ataque intenso da matriz com grande formação de produtos de corrosão na superfície. O contraste entre a matriz e as grafitas, revelou os carbonetos preservados na matriz. Nota-se nas imagens apresentadas que ambos os materiais apresentam intensa corrosão da matriz nas duas soluções em que os ensaios de imersão foram conduzidos, ocorrendo à preservação da grafita e 
indicando o mecanismo de grafitização em todos os meios testados. No entanto, a fase "steadita", no material perlítico, e os carbonetos, no material bainítico apresentam-se mais resistentes à corrosão em comparação à matriz nos diversos tempos de imersão. Outro ponto observado foi que o ataque da matriz em ambos os materiais foi mais acentuado na solução de condensado sintético em comparação ao condensado natural, conforme esperado.

Na figura 43 apresentam-se imagens por microscopia ótica das secções transversais do material com microestrutura perlítica após diferentes períodos de imersão em condensado natural.
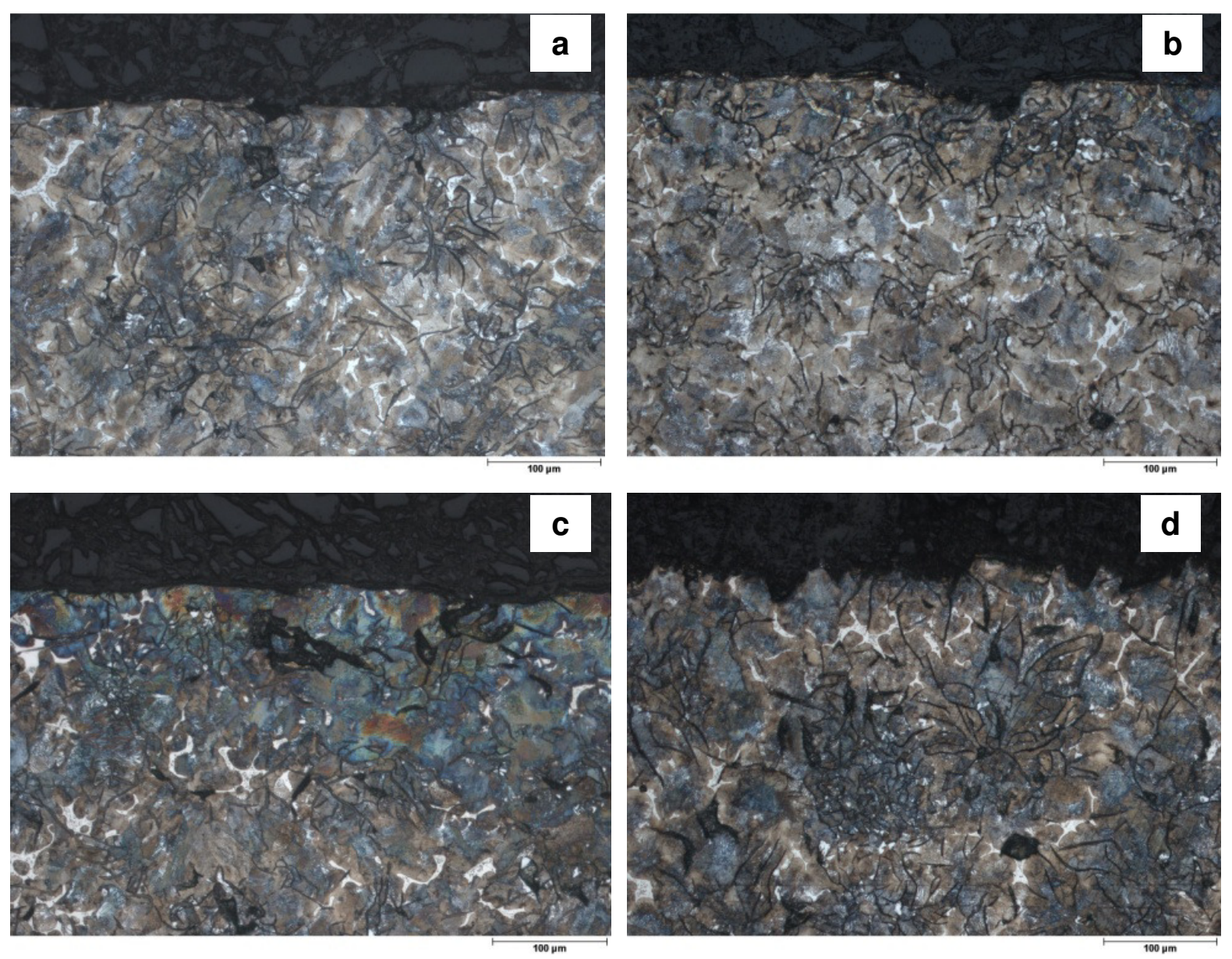

Figura 43 - Imagens por microscopia ótica das secções transversais das amostras do ferro fundido perlítico após ensaio de imersão no condensado natural. (a) 2 horas, (b) 5 horas (c) 16 horas e (d) 120 horas de imersão.

Foi possível notar que a formação dos produtos de corrosão aumentou com o tempo de imersão no condensado natural. O ataque na superfície das amostras foi irregular, indicando que a matriz não foi corroída uniformemente, apenas em regiões onde houve uma forte atuação catódica promovida pela grafita. 
Na figura 44 apresentam-se imagens por microscopia ótica das secções transversais do material com microestrutura perlítica após diferentes períodos de imersão em condensado sintético. Nota-se a forte atuação do meio no processo corrosivo do material, onde a formação de produtos de corrosão foi promovida em maior quantidade em comparação ao condensado natural. Em tempos de imersão como $16 \mathrm{~h}$ e $120 \mathrm{~h}$ observou-se que nos produtos de corrosão a fase eutética fosforosa steadita estava preservada e ancorando os produtos.
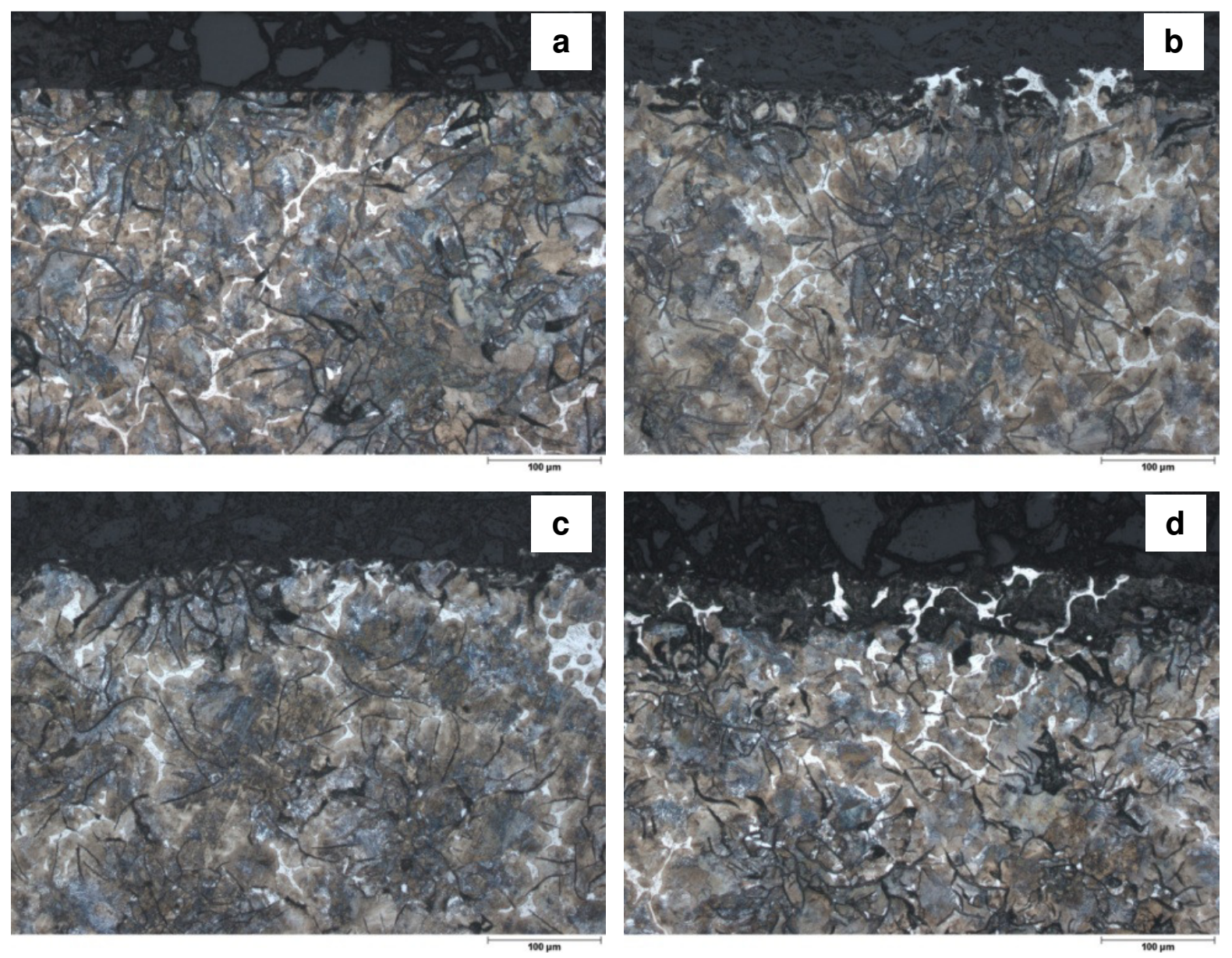

Figura 44 - Imagens por microscopia ótica das secções transversais das amostras do ferro fundido perlítico após ensaio de imersão no condensado sintético. (a) $2 \mathrm{~h}$, (b) $5 \mathrm{~h}$, (c) $16 \mathrm{~h}$ e (d) $120 \mathrm{~h}$ de imersão.

$\mathrm{Na}$ figura 45 apresentam-se as imagens das secções transversais obtidas por microscopia ótica, das amostras do material com microestrutura bainítica após ensaio de imersão em condensado natural.

O material de microestrutura bainítica, apresentou pouca formação de produtos de corrosão nas amostras ensaiadas em meio de condensado natural. Em comparação ao material de microestrutura perlítica, o material bainítico 
apresentou um ataque mais homegênio da matriz, observado nas secções metalograficas.
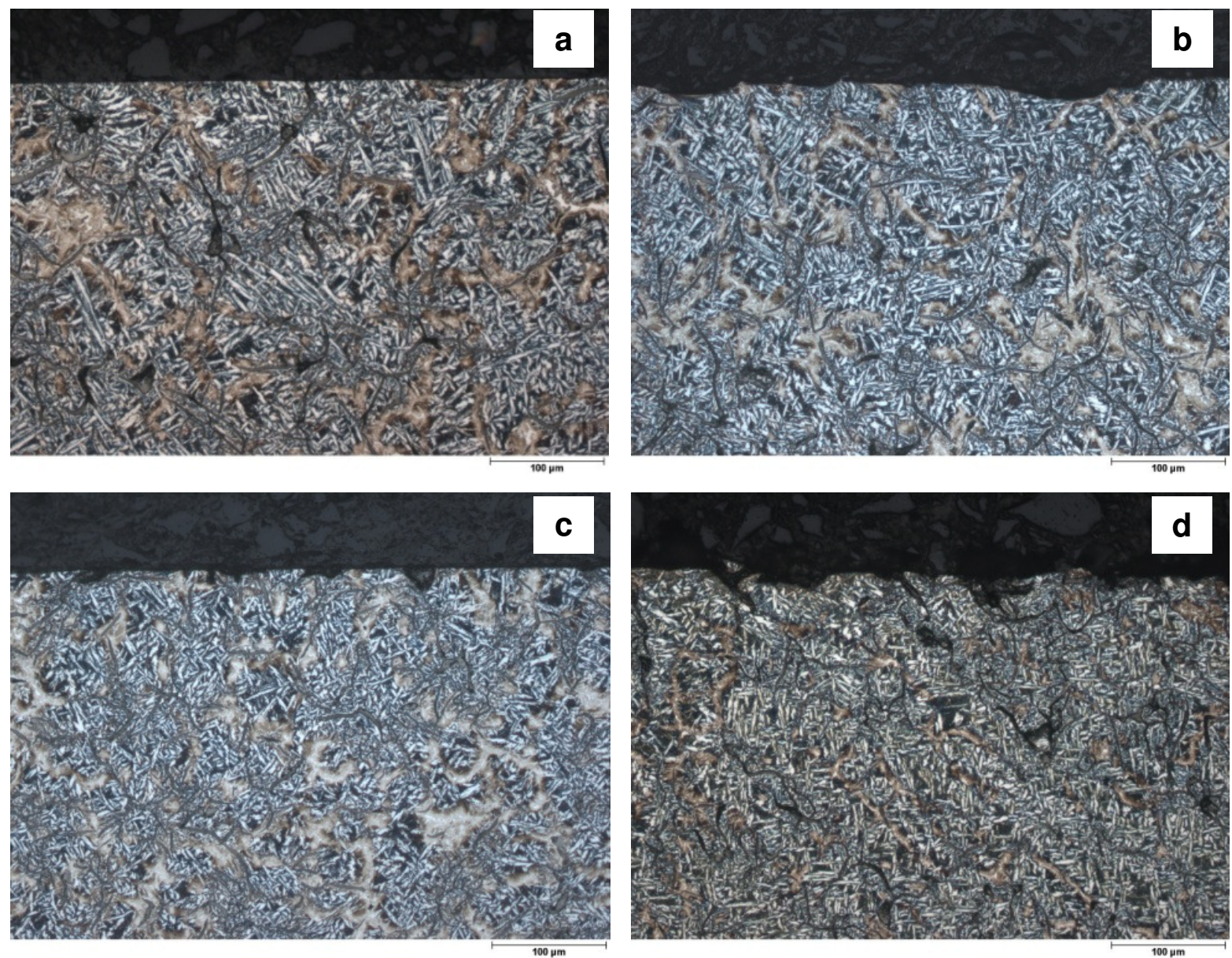

Figura 45 - Imagens por microscopia ótica das secções transversais das amostras do ferro fundido bainítico após ensaio de imersão no condensado natural. (a) $2 \mathrm{~h}$, (b) $5 \mathrm{~h}$, (c) $16 \mathrm{~h} \mathrm{e} \mathrm{(d)} 120 \mathrm{~h}$ de imersão.

Na figura 46 apresentam-se imagens das secções transversais obtidas por microscopia ótica, das amostras do material com microestrutura bainítica após os ensaios de imersão em condensado sintético. 

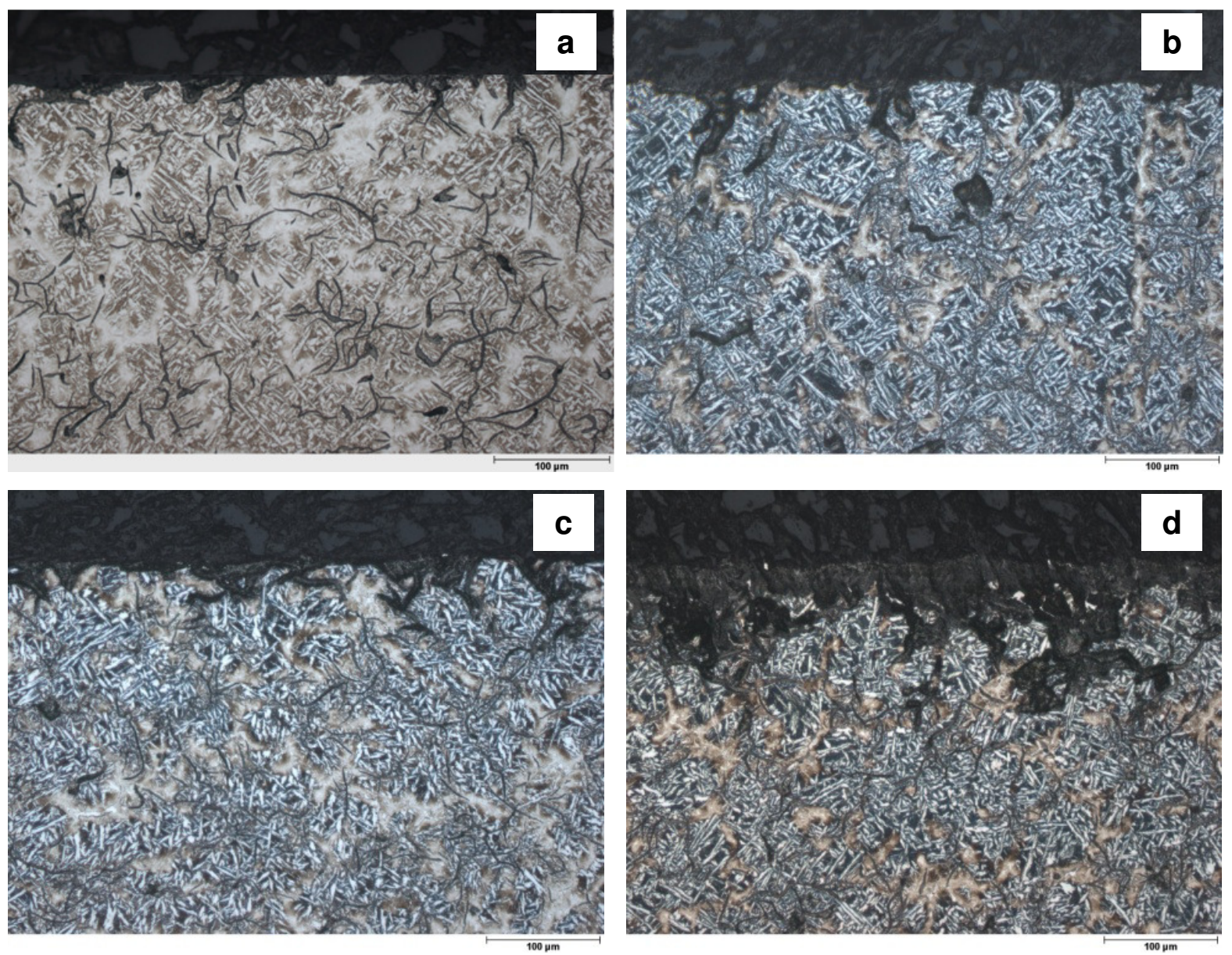

Figura 46 - Imagens por microscopia ótica das secções transversais das amostras do ferro fundido bainítico após ensaio de imersão no condensado sintético. (a) $2 \mathrm{~h}$, (b) $5 \mathrm{~h}$, (c) $16 \mathrm{~h}$ e (d) $120 \mathrm{~h}$ de imersão.

Nota-se que a profundidade da corrosão nas amostras submetidas ao ensaio em meio de condensado sintético é maior em comparação ao condensado natural em ambos os materiais.

$\mathrm{Na}$ figura 47 compararou-se as secções transversais das duas amostras ensaiadas, ferro fundido bainítico e ferro fundido perlítico na solução de condensado sintético, após 120 h de imersão. Nota-se uma profundidade de penetração do ataque corrosivo maior no caso do material bainítico particulamente em algumas regiões comparando-se com o material perlítico. Sugere-se que a fase "steadita", praticamente inerte no meio usado, "ancora" os produtos de corrosão resultantes do ataque da matriz. Este efeito de ancoragem resulta na formação de uma camada com o efeito de barreira a qual dificulta o acesso do meio corrosivo ao material metálico sob esta camada. Esta seria a provável causa para a comparativamente menor profundidade de penetração da corrosão neste tipo de material. 
No caso do ferro fundido bainítico, a corrosão grafítica vai abrindo canais devido ao ataque anódico da matriz, o que favorece a criação de condições de fresta no material. Estas condições são muito severas / agressivas à matriz, promovendo a penetração do processo corrosivo.

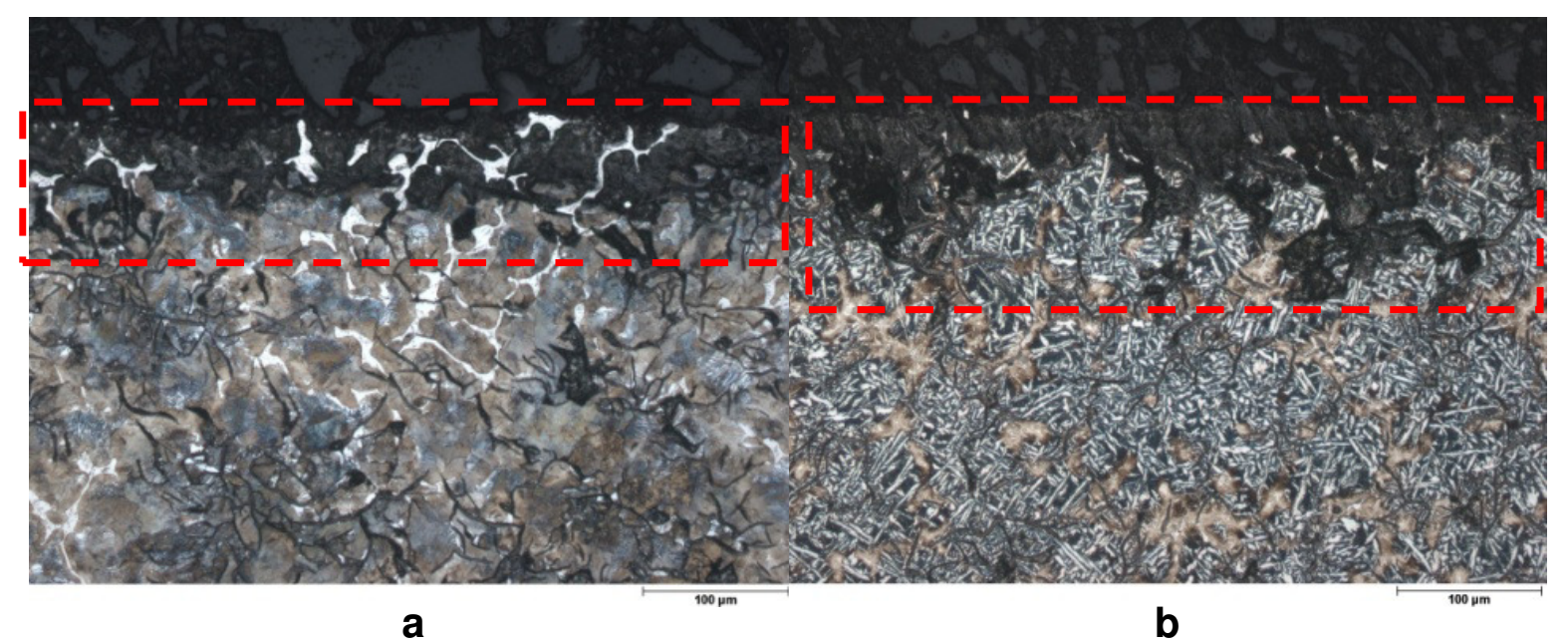

Figura 47 - Imagens por microscopia ótica - Comparação da penetração do ataque corrosivo por observação da secção transversal do ferro fundido perlítico (a) e do ferro fundido bainítico (b), em solução de condensado sintético, após $120 \mathrm{~h}$ de ensaio de imersão.

\subsection{Caracterizações dos produtos solúveis após ensaio de imersão presentes nos condensados.}

Elementos da liga dos ferros fundidos os quais foram solubilizados no meios de ensaio, especificamente dos condensados sintético e natural, em consequência do processo de corrosão dos ferros fundidos estudados, foram analisados quimicamente, conforme descrito no Capitulo 4. Os resultados das concentrações dos elementos $\mathrm{Fe}$ e $\mathrm{Si}$, para vários tempos de imersão, estão apresentados nas tabelas 8 a 11. Estes elementos foram escolhidos por se encontrarem como elementos solúveis na matriz. A concentração destes metais nos dois meios para os dois ferros fundidos estudados, apresentam-se em concentrações similares. Tais resultados apoiam os resultados apresentados anteriormente referentes ao ataque corrosivo da superfície dos ferros fundidos.

Os materiais estudados apresentam a grafita distribuída na matriz em diferentes tamanhos e formatos. Segundo AJELL (2008), o teor e a forma da grafita presente nas ligas de ferro fundido afeta diretamente a resistência à corrosão destes materiais. No caso do material perlítico, as grafitas são maiores que as do bainítico, o que implica áreas catódicas maiores, em comparação às do 
bainítico. Segundo RAMANATHAN (1996), a relação entre área catódica e área anódica tem efeito na taxa de corrosão do material. Isto é esperado, uma vez que a pilha de corrosão depende do funcionamento efetivo de quatro componentes, sendo dois deles, o anodo e o catodo. A corrente gerada na área anódica deve ser efetivamente consumida na catódica. Portanto, uma maior área catódica representa uma maior área para consumo da corrente gerada nas áreas anódicas.Nota-se nas figuras 48 e 49 que a cinética de dissolução dos elementos $\mathrm{Si}$ e Fe foram similares para os dois ferros fundidos, nos dois tipos de meio, condensado natural e sintético. Observa-se também que o condensado natural é um meio bem menos agressivo que o sintético, resultando em teores de elementos dissolvidos da ordem de cinco vezes menores que no condensado sintético.

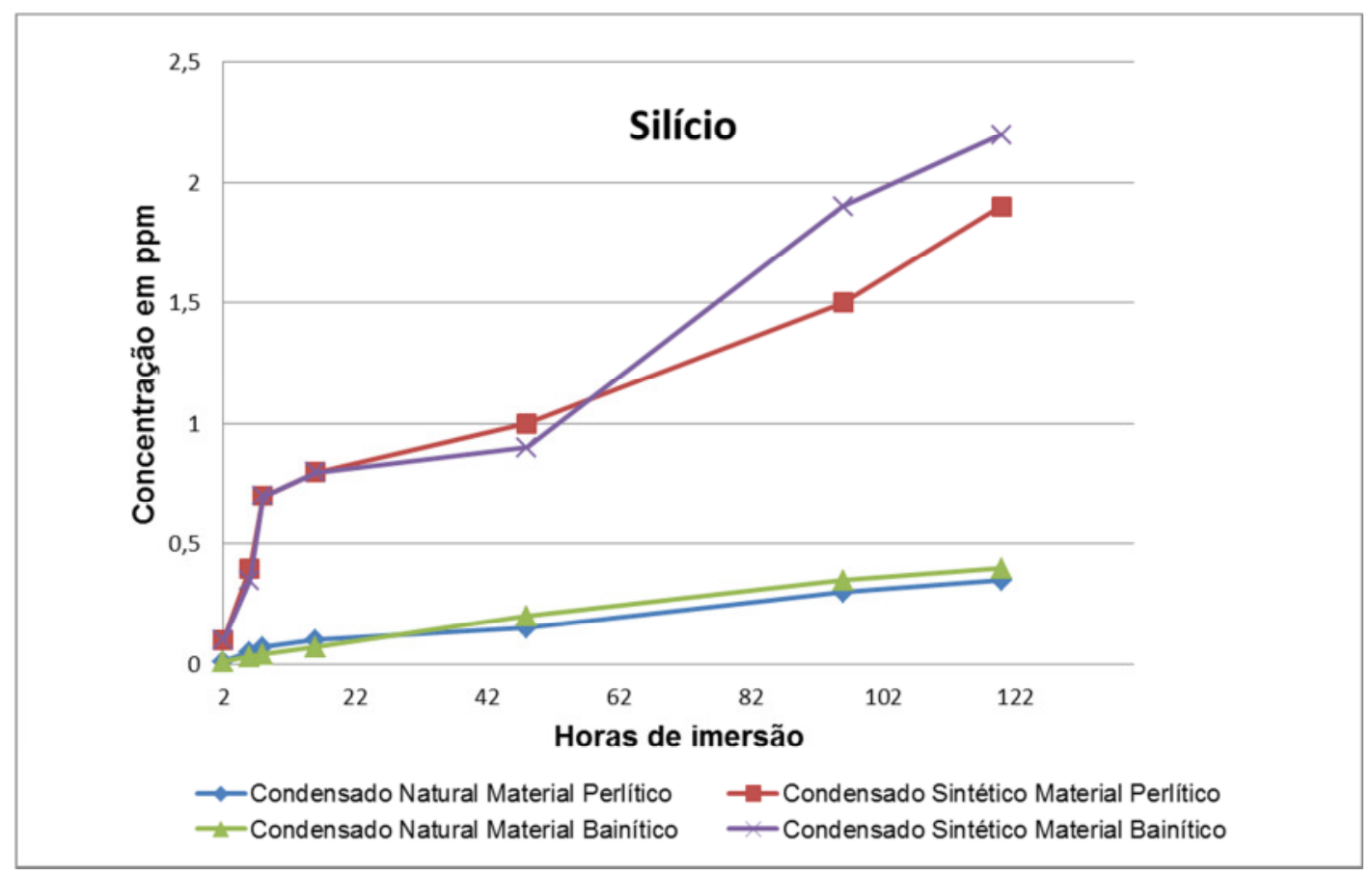

Figura 48 - Evolução da concentração do silício em solução para os materiais de microestrutura perlítica e bainítica em meio dos condensados natural e sintético.

Foram observados teores superiores de íons de ferro e de silício, dissolvidos no meio de condensado sintético, para o material de estrutura perlítica em comparação ao bainíitico. No caso do silício, até 48 horas de imersão a dissolução deste metal no meio de condensado sintético se manteve similar para os materiais perlítico e bainítico. A diferença entre estes, todavia, aumenta para temos superiores a $48 \mathrm{~h}$. Para o condensado natural, os teores dos íons de ferro e de silício no meio foram muito próximos ao longo de todo o período de ensaio. 
Esta observação indica uma similar resistência à corrosão dos dois ferros fundidos estudados, conforme já tinha sido indicado pelos resultados anteriores.

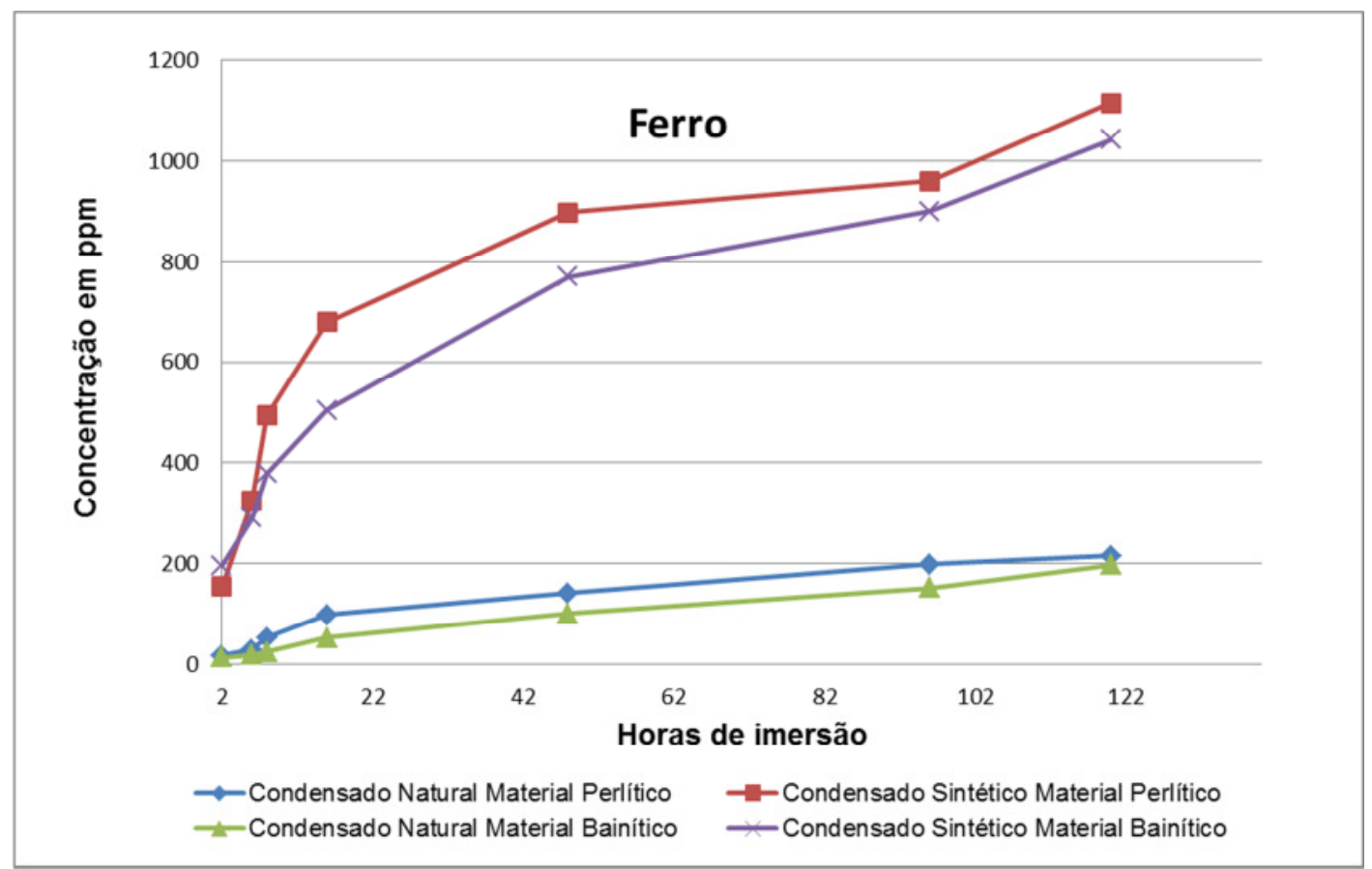

Figura 49 - Evolução da concentração do ferro em solução para os materiais de microestrutura perlítica e bainítica em meio dos condensados natural e sintético.

Tabela 8 - Concentração em ppm, obtido por ICP dos metais dissolvidos no condensado natural durante os ensaios de imersão do material perlítico.

\section{Elementos (ppm)}

\begin{tabular}{cccccccc}
\hline Horas & Cromo & Manganês & Molibdênio & Níquel & Silício & Fósforo & Ferro \\
2 & -- & 0,015 & -- & -- & 0,01 & -- & 17 \\
6 & -- & 0,03 & -- & -- & 0,05 & -- & 39 \\
8 & -- & 0,05 & -- & -- & 0,07 & -- & 53 \\
16 & -- & 0,08 & -- & -- & 0,1 & -- & 98 \\
48 & -- & 0,15 & -- & -- & 0,15 & -- & 167 \\
96 & -- & 0,35 & -- & -- & 0,3 & -- & 320 \\
120 & -- & 0,4 & -- & -- & 0,35 & -- & 401 \\
\hline
\end{tabular}


Tabela 9 - Concentração em ppm, obtido por ICP dos metais dissolvidos pelo condensado natural durante os ensaios de imersão do material bainítico.

\section{Elementos (ppm)}

\begin{tabular}{cccccccc}
\hline Horas & Cromo & Manganês & Molibdênio & Níquel & Silício & Fósforo & Ferro \\
2 & -- & 0,015 & -- & -- & 0,01 & -- & 14 \\
6 & -- & 0,03 & -- & -- & 0,05 & -- & 19 \\
8 & -- & 0,05 & -- & -- & 0,07 & -- & 25 \\
16 & -- & 0,08 & -- & 0,015 & 0,1 & -- & 53 \\
48 & -- & 0,15 & -- & 0,02 & 0,15 & -- & 101 \\
96 & -- & 0,35 & -- & 0,05 & 0,3 & -- & 152 \\
120 & -- & 0,4 & -- & 0,08 & 0,35 & -- & 198 \\
\hline
\end{tabular}

Tabela 10 - Concentração em ppm, obtido por ICP dos metais dissolvidos pelo condensado sintético durante os ensaios de imersão para o material perlítico.

Elementos (ppm)

\begin{tabular}{cccccccc}
\hline Horas & Cromo & Manganês & Molibdênio & Níquel & Silício & Fósforo & Ferro \\
2 & -- & 0,6 & 0,06 & -- & 0,1 & 0,2 & 196 \\
6 & 0,015 & 1,5 & 0,065 & -- & 0,4 & 0,3 & 291 \\
8 & 0,02 & 2 & 0,07 & -- & 0,7 & 0,5 & 379 \\
16 & 0,4 & 2,5 & 0,08 & -- & 0,8 & 0,8 & 504 \\
48 & 0,06 & 3 & 0,01 & -- & 1 & 1 & 770 \\
96 & 0,07 & 3,5 & 0,027 & -- & 1,5 & 1,5 & 901 \\
120 & 0,09 & 4 & 0,04 & -- & 1,9 & 2 & 1042 \\
\hline
\end{tabular}

Tabela 11 - Concentração em ppm, obtido por ICP dos metais dissolvidos pelo condensado sintético durante os ensaios de imersão para o material bainítico.

Elementos (ppm)

\begin{tabular}{cccccccc}
\hline Horas & Cromo & Manganês & Molibdênio & Níquel & Silício & Fósforo & Ferro \\
2 & -- & 0,2 & 0,08 & 2,5 & 0,1 & 0,07 & 155 \\
6 & -- & 0,5 & 0,1 & 4 & 0,35 & 0,09 & 325 \\
8 & 0,015 & 0,8 & 0,4 & 5,5 & 0,7 & 0,1 & 494 \\
16 & 0,02 & 1 & 0,7 & 8 & 0,8 & 0,2 & 680 \\
48 & 0,04 & 3 & 0,8 & 9 & 0,9 & 0,3 & 898 \\
96 & 0,06 & 4 & 0,9 & 1 & 1,9 & 0,4 & 960 \\
120 & 0,08 & 5 & 1,2 & 11 & 2,2 & 0,5 & 1115 \\
\hline
\end{tabular}




\subsection{Avaliações da resistência à corrosão através de ensaios eletroquímicos}

$\mathrm{Na}$ investigação da resistência à corrosão dos materiais com microestrutura perlítica e bainítica, alguns ensaios eletroquímicos foram realizados, tais como: medidas de potencial a circuito aberto versus tempo, ensaios de espectroscopia de impedância eletroquímica e curvas de polarização potenciodinâmicas. As duas ligas de ferro fundido foram inicialmente ensaiados por espectroscopia de impedância eletroquímica (EIE) em meio de condensado natural. Todavia, a baixa condutividade desta solução $(30 \mu \mathrm{S} / \mathrm{cm})$ levaram a resultados não confiáveis. A resistência ôhmica estimada, da ordem de $150 \mathrm{ohm}$ $\mathrm{cm}^{2}$, foi muito elevada e na ordem da resistência à transferência na interface metal-meio. Optou-se então pela utilização de uma solução que é usada para simular os efeitos corrosivos do condensado natural, chamada de condensado sintético. Foram realizados ensaios com esta solução, porém esta também se mostrou muito agressiva, com valores de resistência muito baixos, obtidos para esta solução. A solução de condensado sintético foi então diluída para 1/10 da concentração inicial e apresentou uma condutividade de $380 \mu \mathrm{S} / \mathrm{cm}$. Os resultados obtidos nesta solução são apresentados na figura 50, como diagramas de Nyquist para $2 \mathrm{~h}$ de imersão. Os resultados mostram que a resistência à transferência de carga em condensado sintético diluído foi inicialmente (2h de imersão) da ordem de $190 \mathrm{ohms} . \mathrm{cm}^{2}$ para o material perlítico e $160 \mathrm{ohm} . \mathrm{cm}^{2}$ para o material bainítico. Apesar de os resultados indicarem uma resistência ligeiramente menor do ferro fundido bainítico em relação ao perlítico, deve-se salientar que os valores são muito próximos e devem estar dentro do erro experimental da medida. Procurando uma melhor diferenciação na resistência à corrosão dos materiais estudados, optou-se então pela utilização de uma solução de cloreto de sódio $0,1 \mathrm{~mol} \mathrm{~L}^{-1}$ para realização dos ensaios de polarização e impedância eletroquímica. Esta solução é comumente utilizada na caracterização da resistência à corrosão de materiais metálicos por ensaios eletroquímicos. Caracteriza-se por ser uma solução aproximadamente neutra e aerada, diferentemente dos condensados usados, que apresentaram caráter ácido.

A figura 51 apresenta os resultados de EIE para os materiais de microestrutura perlítica e bainítica em meio de solução de cloreto de sódio $0,1 \mathrm{~mol}$ $\mathrm{L}^{-1}$. É possível observar uma clara diferença entre a resistência à corrosão dos dois ferros fundidos estudados neste último meio. Um arco capacitivo achatado é 
observado para os dois materiais, mas o diâmetro referente ao material bainítico é cerca de cinco vezes maior que o do perlítico. Observa-se um arco indutivo nas frequências mais baixas para os dois materiais testados, o que indica a dissolução intensa do ferro no meio corrosivo. Segundo WOLYNEC (1994), arcos capacitivos maiores sugerem maior resistência à transferência de carga na interface metal/liquido.

A indicação de maior resistência à corrosão do material bainítico é apoiada pelas curvas de polarização mostradas na figra 52. Embora as inclinações de Tafel referentes às curvas anódicas sejam similares para os dois ferros fundidos, a curva de polarização catódica do material de estrutura bainítica apresenta-se mais inclinada em relação ao de estrutura perlítica. Este resultado indica que as reações catódicas no ferro fundido bainítico são mais polarizadas, ou de mais difícil cinética, do que no perlítico. Isto pode ser explicado pela comparação da proporção de áreas de fase grafita em relação à área da matriz, nos dois materiais estudados, cujos resultados serão apresentados na sequencia deste trabalho.

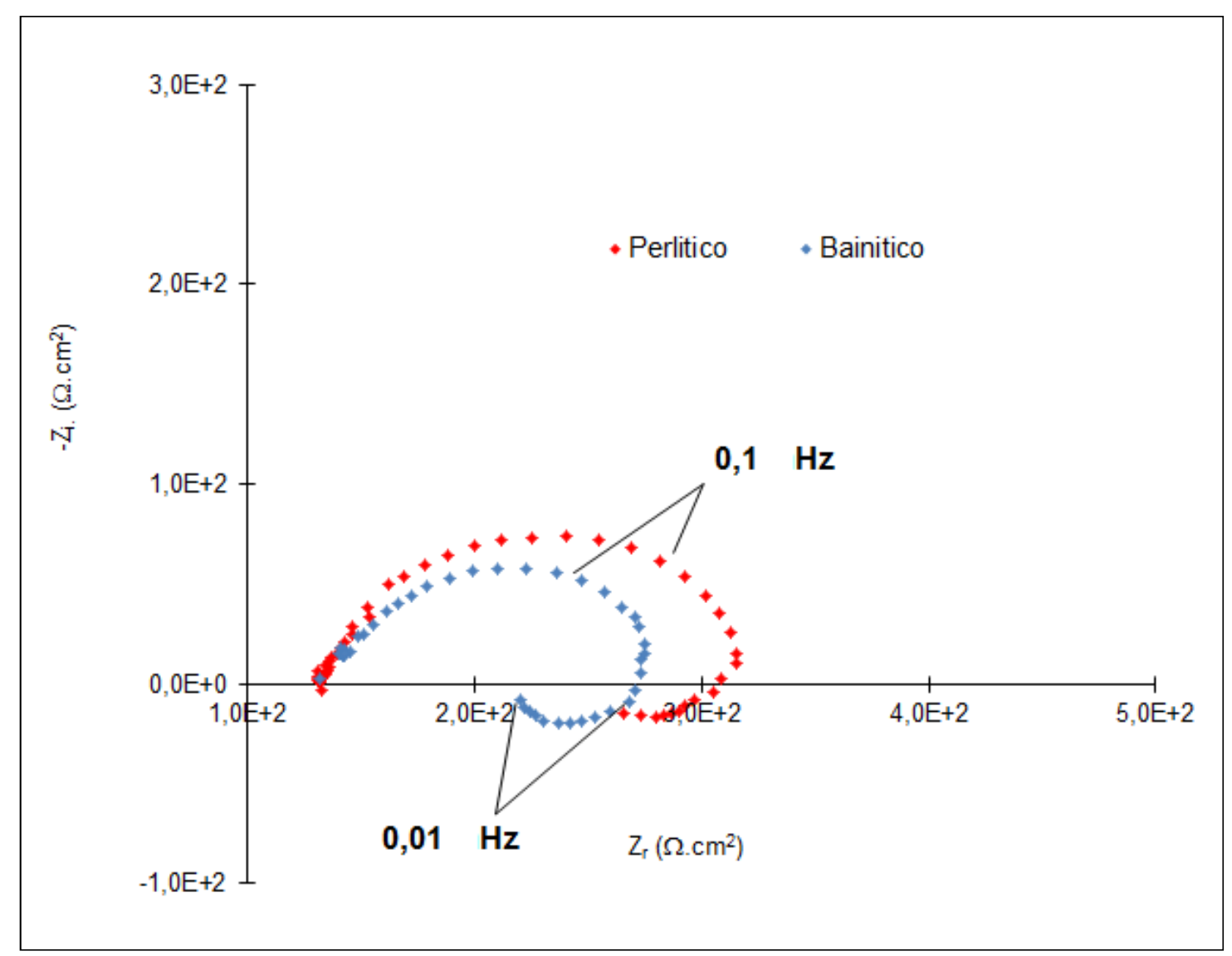

Figura 50 - Diagramas de Nyquist para os ferros fundidos perlítico e bainítico, após $2 \mathrm{~h}$ de imersão, em meio de condensado sintético diluído. 


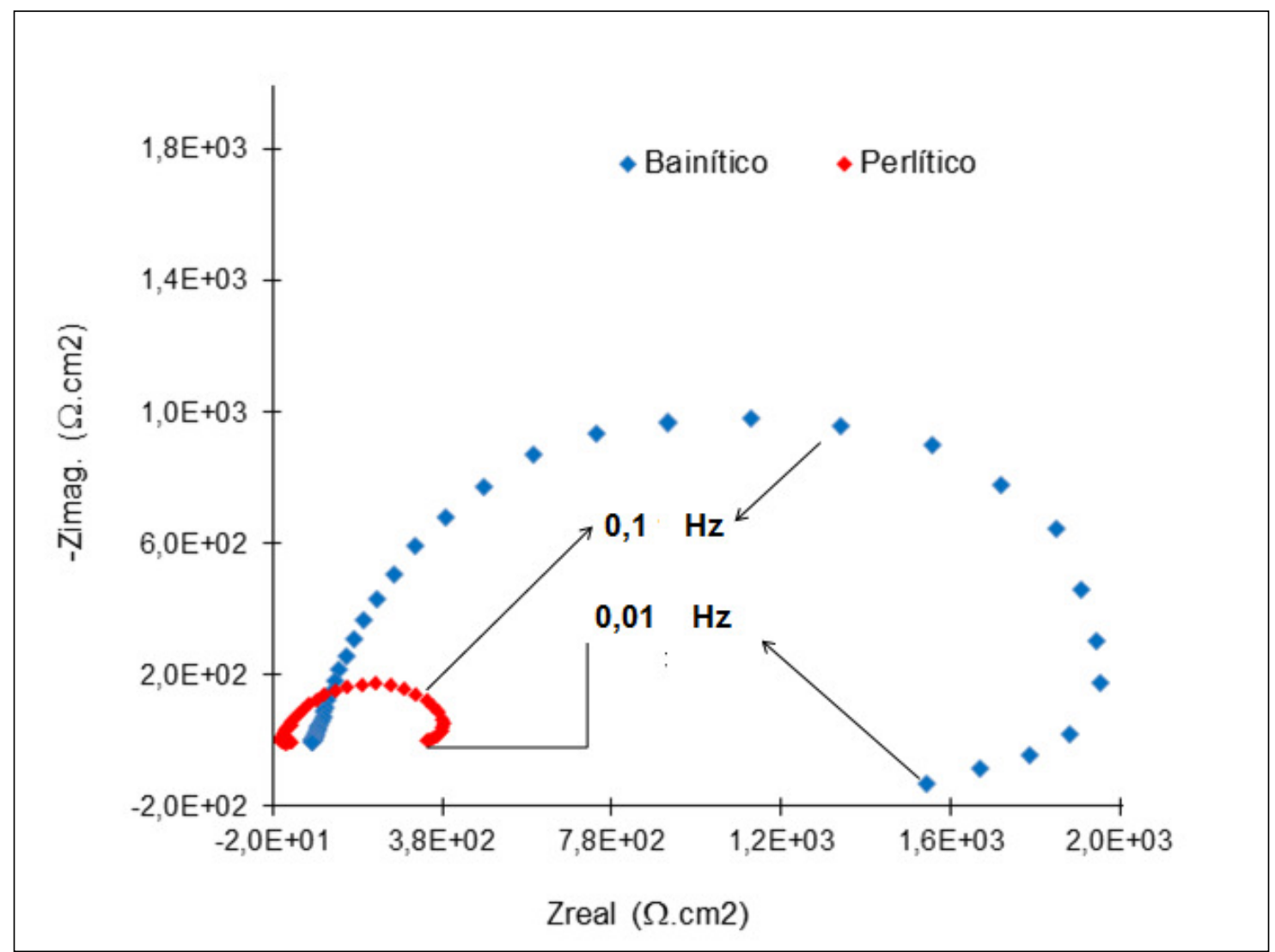

Figura 51 - Diagramas de Nyquist para os ferros fundidos de microestrutura perlítica e bainítica, após 2 h de imersão, em meio de solução de cloreto de sódio 0,1 molar.

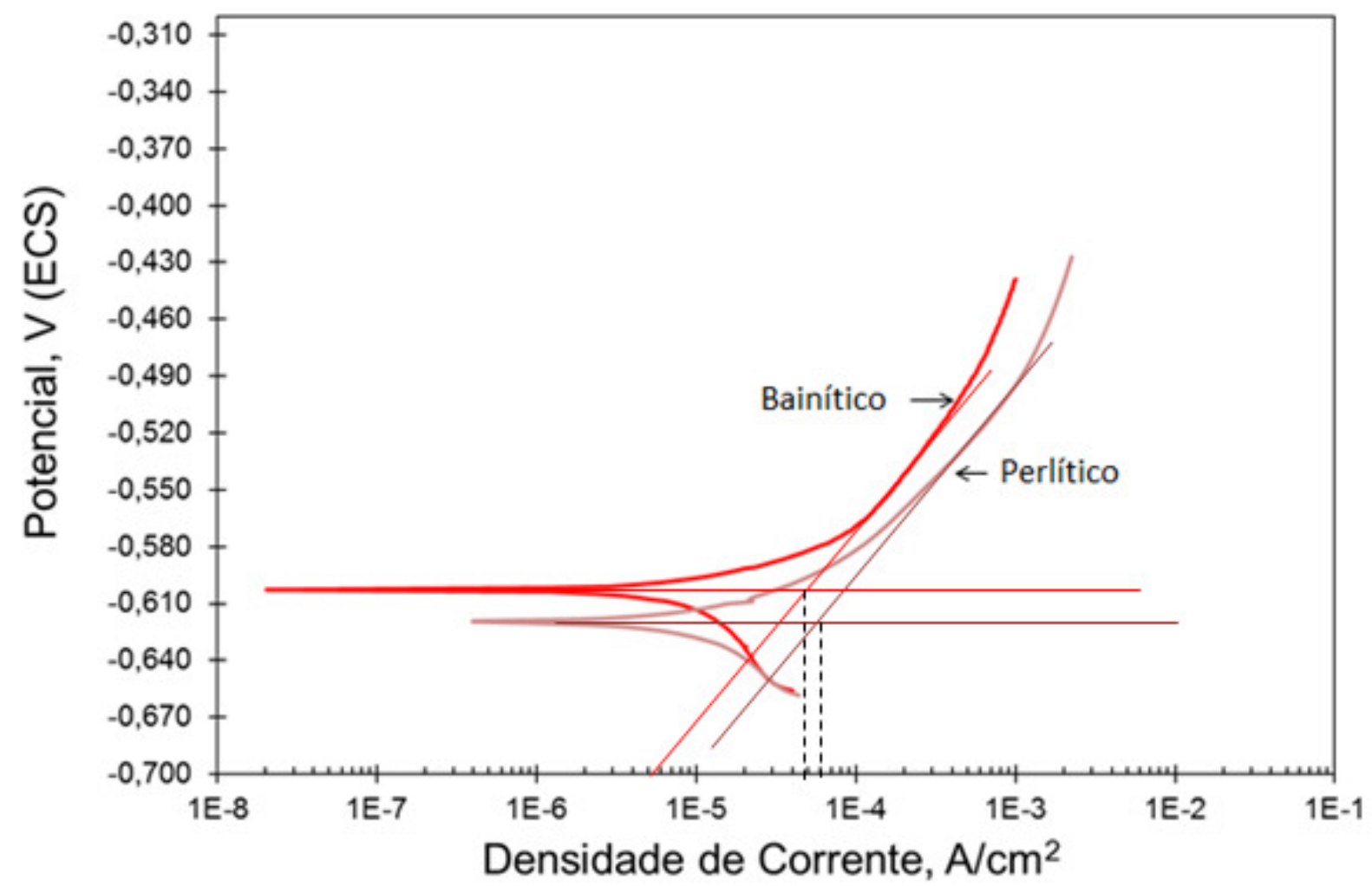

Figura 52 - Curvas de polarização, anódicas e catódicas, obtidas em solução de cloreto de sódio $0,1 \mathrm{~mol} \mathrm{~L}^{-1}$ para os ferros fundidos perlítico e bainítico. 

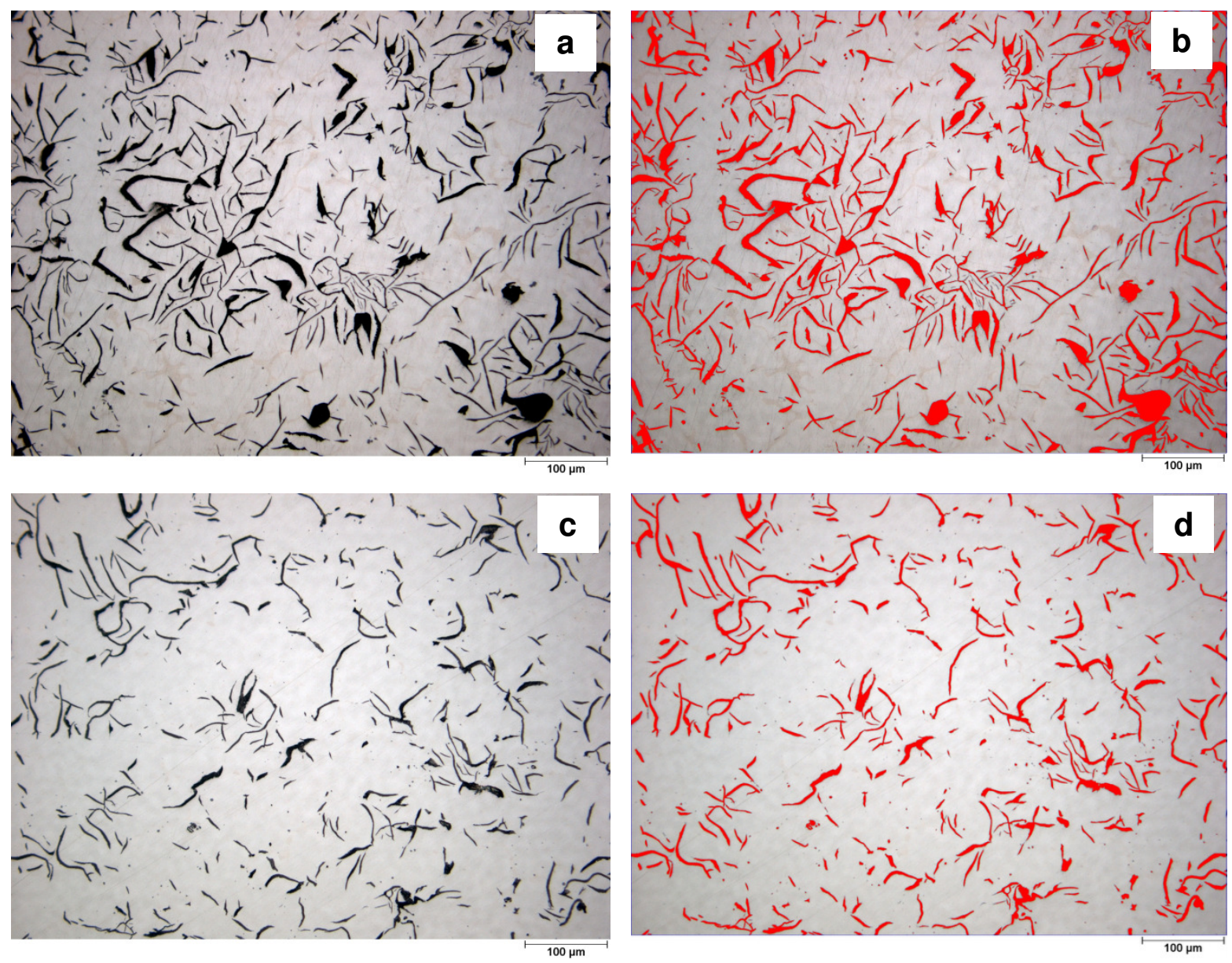

Figura 53 - Análise quantitativa por imagem proporção de áreas de fase grafita em relação à área da matriz. (a) Material perlítico sem quantificação; (b) Material perlítico com quantificação; (c) Material bainítico sem quantificação; (d) Material bainítico com quantificação. 


\section{CONCLUSÕES}

Os resultados do presente trabalho permitem as seguintes conclusões:

- Os ferros fundidos perlítico e bainítico apresentam microestruturas complexas com diversas fases dispersas na matriz e grande quantidade de grafitas com tamanhos e formas diferentes. Tais microestruturas são as responsáveis pelo mecanismo de corrosão por grafitização dos dois materiais estudados. A fase grafita atua como área catódica de alta eficiência devido à sua condutividade elétrica e por ser inerte nos meios corrosivos. A diferença de potencial elétrico entre a matriz e a grafita fornece o potencial termodinâmico necessário à manutenção do processo de corrosão.

- A presença da grafita promove ataque intenso da matriz logo nas primeiras horas de imersão em meio de ambos os condensados usados neste estudo como meios corrosivos. No caso do material bainítico, as grafitas se apresentam em menor tamanho, proporcionando ataque mais homogêneo da matriz. No ferro fundido perlítico foi observado que a fase eutética fosforosa ("steadita"), apresentou elevada resistência à corrosão nas soluções testadas, permanecendo na superfície do material. Houve indicação de ancoragem dos produtos de corrosão provenientes do ataque da matriz pela fase fosforosa ("steadita"), o que, aparentemente, diminuiu a taxa de penetração da corrosão.

- No ferro fundido bainítico foi observada a presença de carbonetos de molibdênio dispersos na matriz. Estes apresentaram alta resistência à corrosão nos meios ensaiados, porém estão presentes em baixa quantidade proporcionalmente à fase steadita no ferro perlítico. A baixa quantidade destes carbonetos não proporcionou a ancoragem dos produtos de corrosão, como ocorreu com a fase steadita no ferro fundido perlítico.

- O condensado natural mostrou-se extremamente corrosivo aos dois tipos de ferro fundidos testados. Este resultado explica a alta incidência de corrosão em camisas de cilindros usadas em motores EGR e fabricadas com estes materiais.

- O condensado sintético também foi altamente agressivo para os dois ferros fundidos ensaiados observando-se ataque intenso da matriz já nas primeiras horas de imersão. 
- $\quad$ Com base nos resultados de imersão nos meios de condensado natural ou sintético, não foi possível verificar diferença quanto à resistência à corrosão dos dois materiais estudados. Ambos apresentaram intenso ataque corrosivo nos meios de ensaio, principalmente no condensado sintético.

- $\quad$ Análises químicas dos elementos ferro e silício dissolvidos da matriz nos meios de ensaio, seja o condensado sintético ou o natural, mostraram concentrações similares destes elementos para os ferros fundidos bainítico e perlítico quando comparados em um mesmo meio. Estes resultados apoiam a indicação de resistência à corrosão similar para ambos os materiais nos meios de condensado, natural ou sintético.

- Os resultados dos ensaios de espectroscopia de impedância eletroquímica (EIE) conduzidos em meio do condensado natural foram afetados pelas características do meio, o qual mostrou muito baixa condutividade, produzindo resultados não confiáveis sobre o comportamento eletroquímico na interface ferro fundido-meio.

- $\quad$ O condensado sintético usado como alternativa para avaliar e comparar o comportamento eletroquímico dos dois ferros fundidos testados, mostrou-se altamente corrosivo para os dois materiais, não sendo possível identificar inequivocamente uma diferença quanto à resistência à corrosão entre os ferros fundidos avaliados.

- Ensaios de espectroscopia de impedância eletroquímica, realizados em meio de cloreto de sódio $0,1 \mathrm{~mol} \mathrm{~L}^{-1}$ aerado, permitiu diferenciar a resistência à corrosão dos dois materiais observando-se que o material bainítico apresenta maior resistência à corrosão (ordem de cinco vezes maior) que o material perlítico.

- $\quad$ A menor proporção de área de fase grafita em relação à área da matriz no ferro fundido bainítico em comparação ao perlítico pode ser a provável causa da mairo resistência à corrosão do primeiro em comparação ao último em meios neutros e aerados. Esta diferenciação não foi possível em meios de alta agressividade como os condensados natural e sintético adotados. 


\section{SUGESTÕES PARA TRABALHOS FUTUROS}

1. Caracterização da composição química dos produtos de corrosão formados durante o ensaio de imersão no condensado sintético e natural utilizando a técnica de difração de raios-x e fluorescência de raios-x.

2. Realização do ensaio de corrosão com ciclos de imersão e condensação proposto pela Norma VDA 230-214 para efeito de comparação com os resultados do ensaio de imersão contínua realizado neste trabalho.

3. Ensaios de EIE com o condensado natural, utilizando-se microeletrodos com o objetivo de minimizar a queda ôhmica muito elevada no meio de condensado natural, de baixa condutividade.

4. Realização de ensaio de desgaste na superfície das amostras após os ensaios de corrosão por imersão, para verificação da aderência dos produtos de corrosão formados na superfície dos ferros fundidos.

5. Investigação do efeito de revestimentos DLC e proteção catódica por anodos de sacrifício na proteção contra a corrosão dos ferros fundidos investigados. 
APÊNDICE A - Mapa da situação global para o teor de enxofre no diesel.

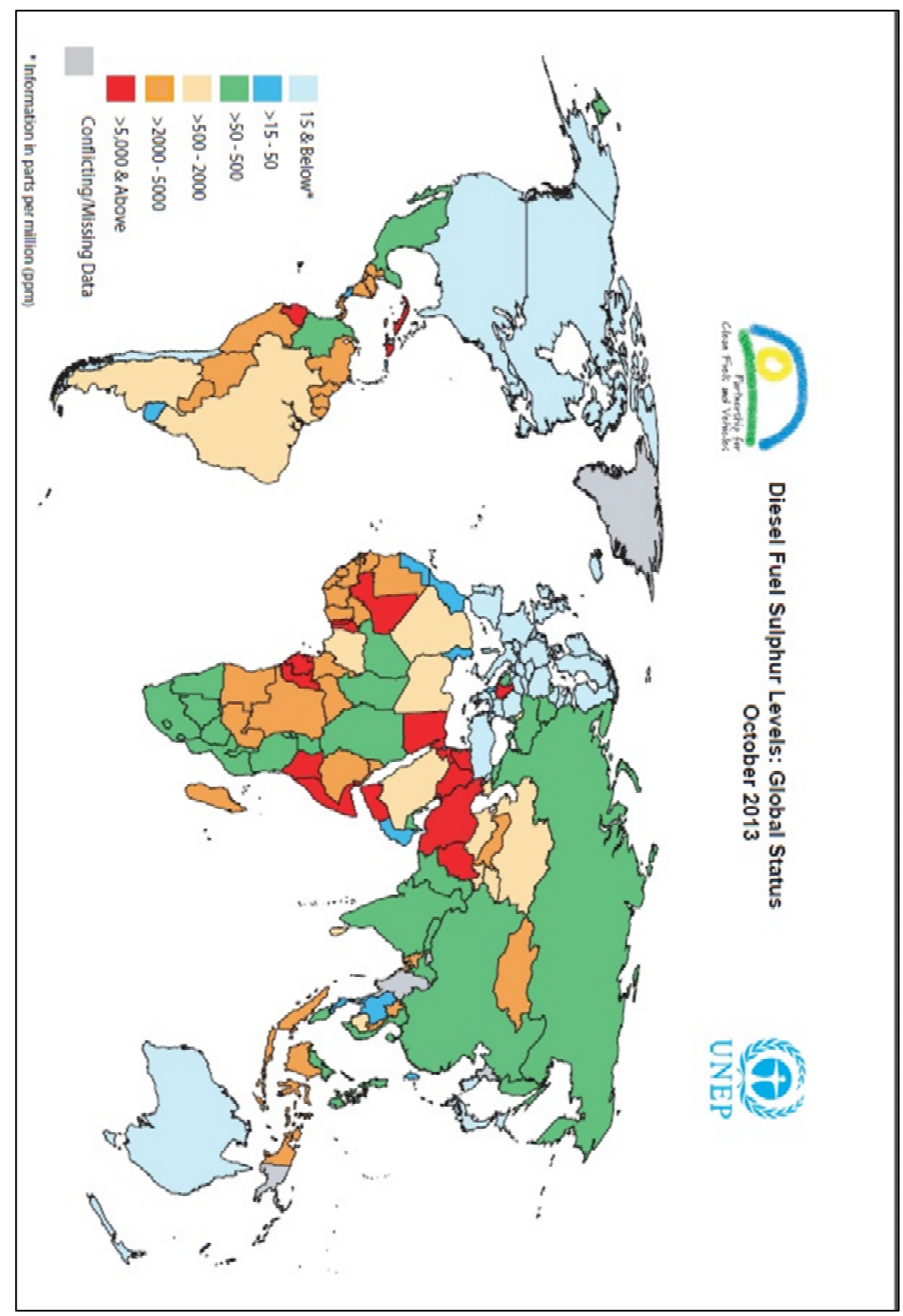

Fonte: UNEP, 2014 
APÊNDICE B - Gradiente térmico típico em camisas de cilindro gerado por simulação de elementos finitos.

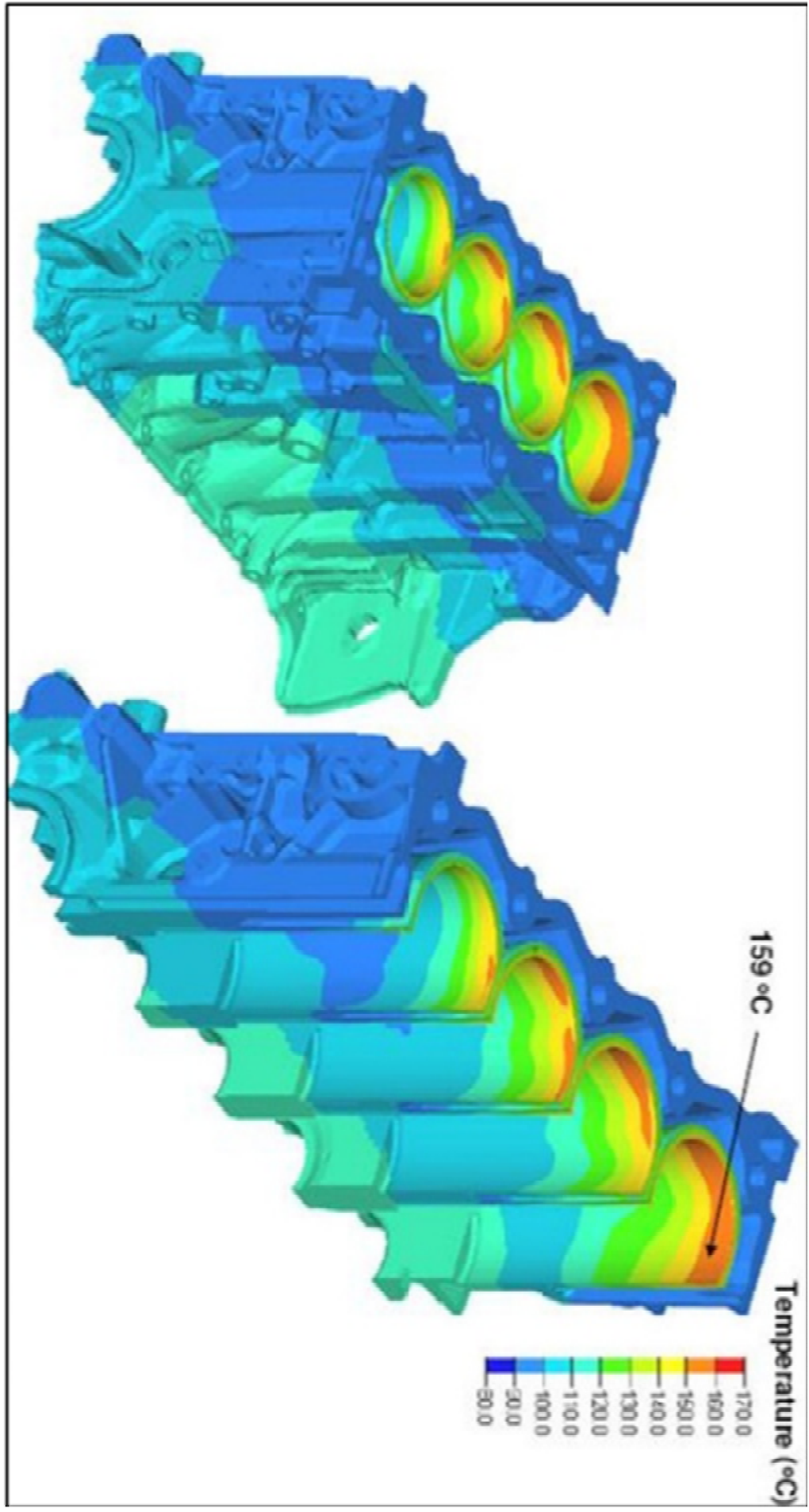

Fonte: REJOWSKI, 2012 


\section{REFERÊNCIAS BIBLIOGRÁFICAS}

AJEEL A. S.; HASONI M.S. Ductile and Gray cast Irons deterioration with time in various $\mathrm{NaCl}$ salt concentrations. Eng.\&Tech. Vol. 26, No. 1, 2008.

AMBROZIN, P. R. A.; KURI, E. S. Corrosão metálica associada ao uso de combustíveis minerais e biocombustíveis. Química Nova, Vol. 32, No. 7, 1910-1916, 2009.

AMERICAN SOCIETY FOR TESTING MATERIALS. Standard Specification for Copper-Base Alloy Centrifugal Castings. ASTM B271

ASSOCIAÇÃO BRASILEIRA DE NORMAS TÉCNICAS. Peças em ferro fundido cinzento classificadas conforme a resistência à tração. Rio de Janeiro: ABNT Set. 1986. (NBR 6589/1986).

ASSOCIATION OF GERMAN AUTOMOBILE. Resistance of metallic materials to condensate corrosion in exhaust gas-carrying components Industry. Belin: VDA, June 2010. (VDA 230-214).

ASM SPECIALTY HANDBOOK: Volume 13. 1996. Cast Iron. 4. ed. U.S.A.: ASM International, 1996. p. 437. Vol. 13.

BARELLA, A. ABC do Ferro Fundido Cinzento. São Paulo. Editora Nobel, 1980.

BARBIERI, J. Aperfeiçoameto de técnica reduz emissão de poluentes em motor a diesel. Jornal da Unicamp - Universidade Estadual de Campinas, Campinas, 7 a 13 de junho de 2010 - ANO XXIV - № 464.

BRAGHETTO, A. Performance analyses of cylinder liners after 330 hours in condensation cycle, Report, MAHLE Metal Leve S/A - São Paulo, 2007.

BRAUN S. Poluição gerada por máquinas de combustão interna movidas a diesel - a questão dos particulados. Estratégias atuais para a redução e controle das emissões e tendências futuras. Química Nova, Vol. 27, No. 3, 472-482, 2003.

BRIDI C. D.; COSTA A. C.; WANDER R. P. Análise das expectativas sobre a implantação da EURO $\mathrm{V}$ no setor de transporte de passageiros. Revista dos Transportes Públicos - ANTP - Ano 34 - 2012 - 1ํquadrimestre.

CARMO, J. D.; MELO H. G.; OLIVEIRA, M. H. Guia Micrográfico dos Ferros Fundidos. SENAI CETEF - SA47a 620.18 - Itaúna 1995.

DI CUNTO, C. J. Estudo da resistência à corrosão de aços inoxidáveis para uso na parte fria dos sistemas de exaustão de veículos, Dissertação de mestrado, IPEN-USP, São Paulo 2005. 
CHIAVERINI, V. Aços e ferros fundidos. ABM - Associação Brasileira de Metais, São Paulo, 6aㅡ edição, 1988.

EKSTRÖM M. Development of ferritic ductile cast iron form increased life in exhaust applications. Tese de Licenciatura, Royal Institute of Technology, SE-100 44 Stockholm, Sweden, 2013.

FERREIRA L. S.; SANTOS M. A.; SOUZA R. G. Análise por cromatografia gasosa de BTEX nas emissões de motor de combustão interna alimentados com diesel e mistura diesel-biodiesel (B10). Química Nova, Vol. 31, No. 3, 539-545, 2008.

FÓFANO, S. Avaliação de técnicas eletroquímicas na monitoração de corrosão por sulfetos em sistemas de água de resfriamento industrial, Dissertação de mestrado em Engenharia e Ciência dos Materiais, Universidade Federal do Paraná, Curitiba 2000.

GERMAN NATIONAL STANDARD. Cast iron - Designation of microstructure of graphite. Germany; DIN, Mar. 2009. (ISO 945:1975).

GENTIL, V. Corrosão. 3ํe edição, Rio de Janeiro, Guanabara dois, 1994.

HARTMANN T.; NUETZEL D. Chromium containing amorphous brazing foils and their resistance to automotive exhaust gas condensate. In: IBSC 5th INTERNATIONAL BRAZING AND SOLDERING CONFERENCE 2012, April 22-25, Las Vegas, Nevada, USA. Proceedings... Las Vegas, Nevada USA: ISBN-13, 2012 (978-1-61503-975-3).

HEYWOOD, J. B. Internal Combustion Engine Fundamentals. McGraw-H International Editions, 1988, p. 12-14, 15-17, 25-28, 715-719, 729-733

HIRAI, Y. E. Estudo comparativo das emissões de aldeídos originados pelo veículo a diesel com o uso de óleo diesel comercial, biodiesel e suas misturas. Dissertação de mestrado, Escola de Engenharia de São Carlos-USP, São Carlos 2009.

SARIN P.; SNOEYINK V. L.; BEBEE J.; KRIVEN W., M. CLEMENT J. A. PhysicalChemical Characteristics of Corrosion scale in Old Iron Pipes. Elsevier Science, Vol. 35, No. 12, pp. 2961-2969, Great Britain, 2001.

KAWAMURA K., STEINBERG S., KAPLAN R. I. Homologous series of C1-C10 monocarboxylic acids and C1-C6 carbonyls in Los Angeles. Atmospheric Environment 34 - Elsevier, p. 4175 - 4191, Los Angeles March 2000.

MAINIER, B. F.; SANDRES C. G.; TAVARES M. S. S. Corrosão por sulfeto de hidrogênio (H2S) e sua implicações no meio ambiente e na segurança industrial. In: CIBIM 8 CONGRESSO IBERO AMERICANO DE ENGENHARIA MECÂNICA 2007, Outubro 23-25, Cusco, Peru. Proceedings... Cusco, Peru: CIBIM8, 2007. 
MAHLE, METAL LEVE SA. Manual Técnico para aftermarket. Curso MAHLE Metal Leve - Motores à combustão interna, 2012.

Disponível em:

http://www.mahle.com/C1256F7900537A47/vwContentByKey/W28HPJTN971ST

ULDE/\$FILE/Manual_mahle_brochura\%20-\%2099-164_segunda\%20parte.pdf>.

Acesso em: 30 oct. 2013.

MATERIAL SPECIFICATION. Nickel molybdenum alloyed gray iron centrifugal casting for cylinder liners. Stuttgart: MML, Jan. 2002. (F4027)

MATERIAL SPECIFICATION. Chromium molybdenum alloyed gray iron centrifugal casting for cylinder liners. Stuttgart: MML, May. 2002. (D2623)

MENEZES, R. M. Resistência a corrosão de aços inoxidáveis em solução sintética de condensado de álcool combustível, Dissertação de Mestrado, UEMG, Ouro Preto, 2010.

MEHRA R.; SONI A. Cast iron deterioration with time in various aqueous salt solutions. Bull. Mater. Sci., Vol. 25, No. 1, February 2002

MOHEBBI H.; LI C. Q. Experimental investigation on corrosion of cast iron pipes, Hyundai Publishing Corporation. International Journal of Corrosion. Article ID 506501, doi:10.1155/2011/506501, UK 2011.

MISAWA T.; SUETAKA W.; SHIMODAIRA S. The mechanism of atmospheric rusting and the effect of $\mathrm{Cu}$ and $\mathrm{P}$ on the rusting formation of low alloy steel. Corrosion Science, Oxford V. 11, n. 1, p. 35 - 48, Jan. 1971.

MIYATA Y., KUWAHARA Y., ASAKURA S., SHINOHARA T., YAKOU T., SHIIMOTO K. Anodic Dissolution of Spheroidal Graphite Cast Iron with Different Pearlite Areas in Sulfuric Acid Solutions. International Journal of Corrosion. Volume 2013, Article ID741378, 2013.

OLIVEIRA A. C. P.; BERTAZZOLI R. Determinação da densidade de corrente de corrosão em meio de baixa condutividade: uso de microeletrodos para minimizar a queda ohmica. Química Nova, Vol. 34, No. 2, 325-329, 2011

PRATES, S. E. P. Avaliação da resistência a corrosão de aços inoxidáveis em sistemas de exaustão de veículos, Dissertação de mestrado, UEMG, Outubro 2009.

POURBAIX, M. Atlas of Electrochemical Equilibrium in Aqueous Solutions. NACE International. Houston, Texas, USA, 1976

PRASANNA N. D.; MURALIDHARA M. K.; AGARWAL K. M.; RADHAKRISHNA K. Mechanical Properties and Corrosion Characteristics Grade Ductile Iron. In: 57th INTERNATIONAL FOUNDRYMEN CONGRESS, December 1, Osaka. Proceeding... Osaka, 2009. (IS400/12) 
RAMANATHAN, V. L. Corrosão e seu controle, Hemus, 1990.

RAMOS, S. D. Estudo de aspectos cinéticos da transformação bainítica incompleta em ferros fundidos nodulares austemperados, Dissertação de mestrado, Instituto Superior Tupy, Joinville 2008.

REJOWSKI E. Caracterização e desempenho de um filme de carbono amorfo hidrogenado tipo diamante (a-C:H) dopado com silício, aplicado em camisa de cilindro de motor à combustão interna, Dissertação de mestrado, IPEN-USP, São Paulo 2012.

SANTOS, O. H. Caracterização de camisas de cilindro em ligas Al-Si hipereutéticas e investigação do comportamento de corrosão em meio de condensado sintético automotivo, Tese de Doutorado, IPEN-USP, São Paulo 2006.

SCHNAKENBERG H. G.; BUGARSKI D. A. Review of technology available to the underground mining industry for control of diesel emissions. CDC Workplace Safety and Health. Information Circular IC 9462, Pittsburgh, PA, August 2002

SIDDARAJU C., PRASANNA N. D., MURALIDHARA M. K. Corrosion Characteristics of Ductile Iron Castings Subjected to Austempering Heat Treatment. Indian Foundry Journal. The paper was originally presented at 60th Indian Foundry Congress held during March 2-4, 2012 in Bangalore Vol. 59 No. 1 January 2013

UNITED NATIONS ENVIRONMENT PROGRAMME. Diesel Fuel Sulphur Levels: Global Status October 2013.

Disponível em:

http://www.unep.org/transport/PCFV/PDF/Maps_Matrices/world/sulphur/MapWorldSul phur_October2013.pdf

Acesso em: 10 jan. 2014.

UKOBA, O.K; OKE, P.K; IBEGBULAM, M.C. Corrosion Behavior of Ductile Iron in Different Environment. International Journal of Science and Technology. Volume 2 No.9, September 2012. ISSN 2224-3577, 2012.

VON V. Condensation of water vapor and acid mixtures from exhaust gases. Dissertação de mestrado, Technischen Universität Berlin - Institut für Energietechnik, Berlin 2004.

WOLYNEC, S. Técnicas eletroquímicas em corrosão. São Paulo: Edusp, 2003.

YAHAGI Y.; HOTTA Y. S.; NAGASAWA M. Y. Corrosive Wear of Cast Iron under reciprocating lubrication. In: INTERNATIONAL FUELS AND LUBRICANTS MEETING AND EXPOSITION PHILADELPHIA 1986, October 6-9, Pennsylvania.

Proceedings... Pennsylvania, Philadelphia USA: Toyota Central Res. \& Dev. Labs., Inc. 861599. 